San Jose State University

SJSU ScholarWorks

Master's Projects

Master's Theses and Graduate Research

Spring 2015

\title{
Reducing Waste with Reusable Bag Ordinances and Plastic Bag Bans in the Bay Area: An Impact Analysis
}

Michael Thomas

San Jose State University

Follow this and additional works at: https://scholarworks.sjsu.edu/etd_projects

Part of the Environmental Policy Commons, Public Administration Commons, and the Public Policy Commons

\section{Recommended Citation}

Thomas, Michael, "Reducing Waste with Reusable Bag Ordinances and Plastic Bag Bans in the Bay Area: An Impact Analysis" (2015). Master's Projects. 412.

DOI: https://doi.org/10.31979/etd.szwe-4yvn

https://scholarworks.sjsu.edu/etd_projects/412

This Master's Project is brought to you for free and open access by the Master's Theses and Graduate Research at SJSU ScholarWorks. It has been accepted for inclusion in Master's Projects by an authorized administrator of SJSU ScholarWorks. For more information, please contact scholarworks@sjsu.edu. 


\title{
Reducing Waste with Reusable Bag Ordinances and Plastic Bag Bans in the Bay Area:
}

\section{An Impact Analysis}

\author{
by \\ Michael Thomas \\ A Thesis Quality Research Paper \\ Submitted in Partial Fulfillment of the \\ Requirements for the \\ Masters Degree \\ in \\ PUBLIC ADMINISTRATION \\ Prof. Garrick Percival, Ph.D. \\ The Graduate School \\ San Jose State University \\ May 4, 2015
}




\section{Table of Contents}

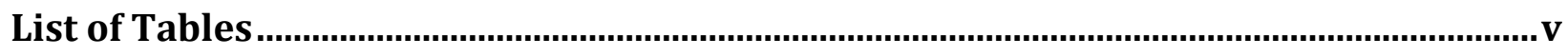

List of Figures

Introduction ...............................................................................................................................

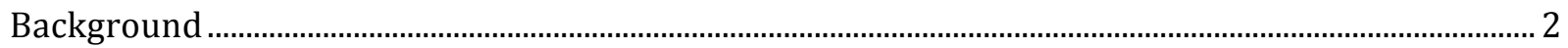

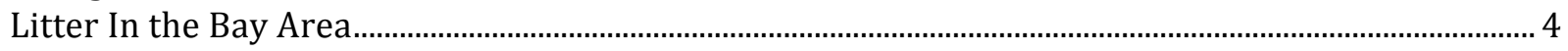

California's Legislators Debate Plastic Bags .................................................................................................. 6

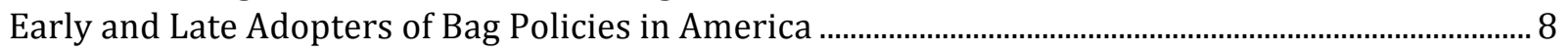

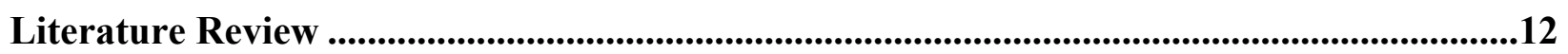

Litter Trends At Home and Abroad ............................................................................................................ 12

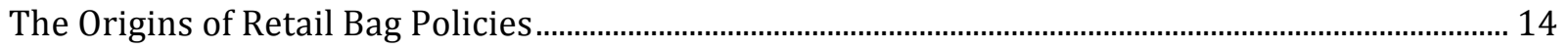

Environmental Impacts of Paper and Plastic Bags .................................................................................... 16

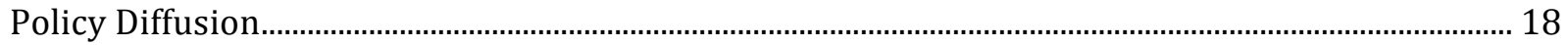

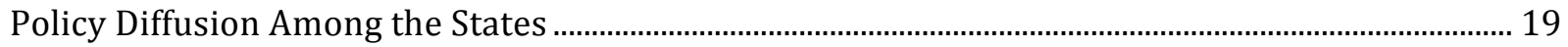

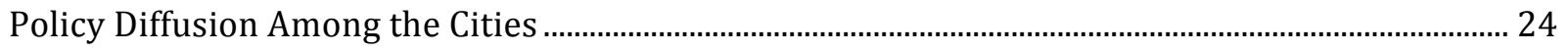

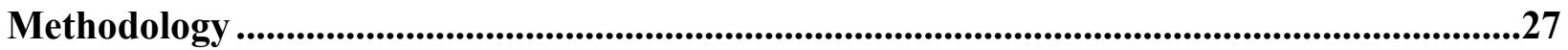

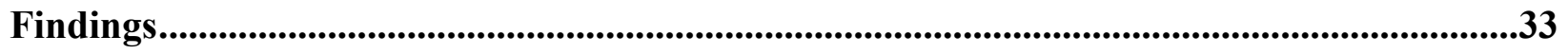

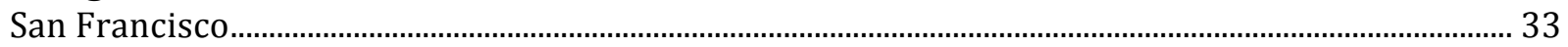

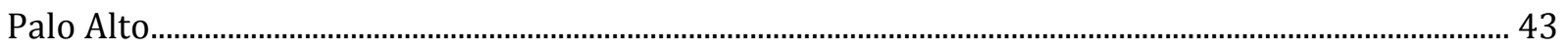

Retail Bag Trends Pre and Post Ordinance Expansion ............................................................49

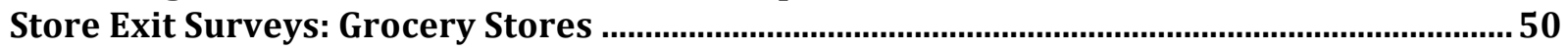

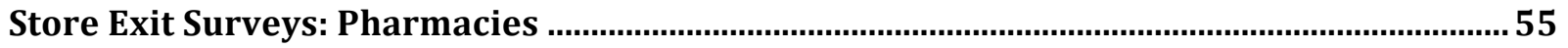

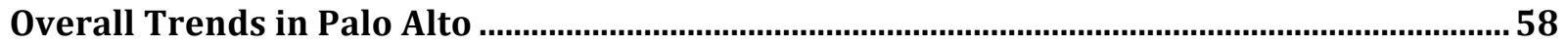

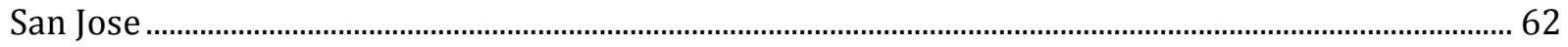

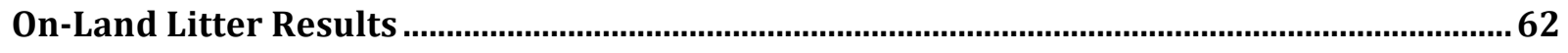

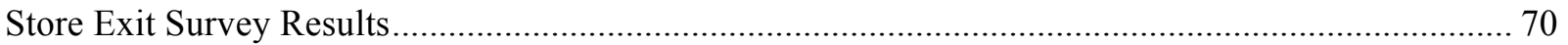

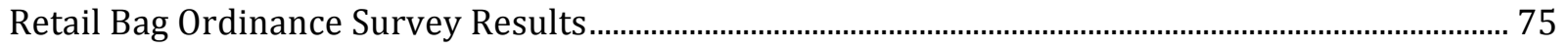

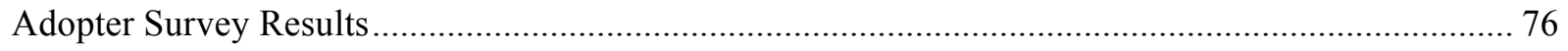

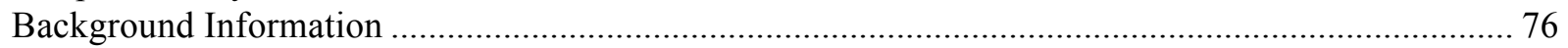

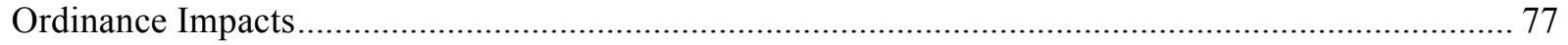

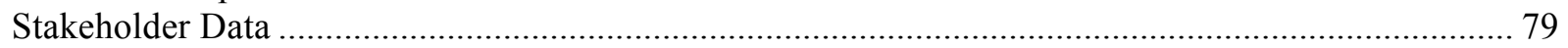

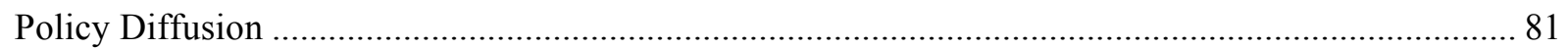

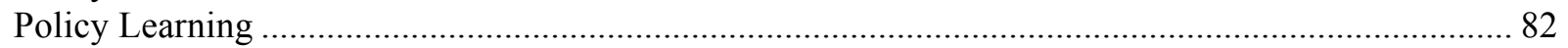

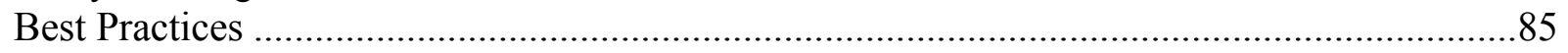

Non-Adopter Survey Results............................................................................................... 85

Background Information ………………………………………………………………. 85

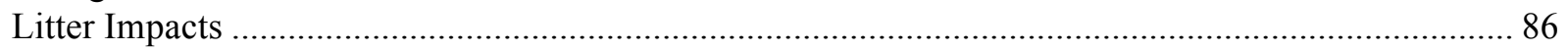

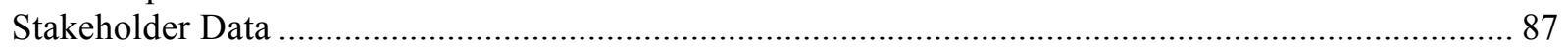

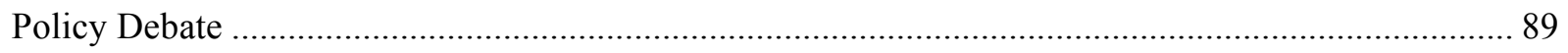

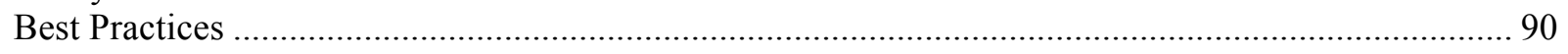

Analysis ...............................................................................................................................90

Conclusion ........................................................................................................................................99

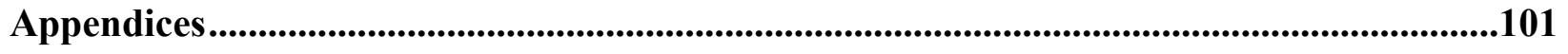

References........................................................................................................................................129 


\section{List of Tables}

Table 1: Comparison of Large Litter Data Results $(2007-2009) \ldots \ldots \ldots \ldots \ldots \ldots \ldots \ldots \ldots . . .34$

Table 2: All Paper \& Fiber Litter - 2009 Audit..........................................35

Table 3: San Francisco Large Litter Summary Count Results:

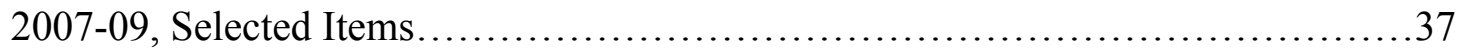

Table 4: San Francisco Bag Litter: Percentage of Large Litter, 2007-09, Bag

Sub-Category Detail.......................................................41

Table 5: 2013 Palo Alto Creek Cleanup Events

Matadero Creek and Adobe Creek.........................................45

Table 6: Adobe Creek Trash Boom Collection Results - September 2013..............46

Table 7: Palo Alto Disposable Checkout Bag Ordinance

Store Exit Surveys of Customer Bag Types: Grocery (2008-14)...................53

Table 8: Palo Alto Disposable Checkout Bag Ordinance

Store Exit Surveys of Customer Bag Types: Pharmacy (2008-14)..................57

Table 9: Palo Alto Disposable Checkout Bag Ordinance

Store Exit Surveys of Customer Bag Types: Combined (2008-14) ...................60

Table 10: On-Land Litter Survey Results.....................................63

Table 11: San Jose On-Land Litter Assessment, 2009..............................64

Table 12: San Jose On-Land Litter Assessment, 2010............................65

Table 13: San Jose On-Land Litter Assessment, 2012 ...........................66

Table 14: Storm Drain Trash Characterization.......................................68

Table 15: Creek and River Cleanup Characterization.............................69

Table 16: Visual Bag Observations......................................... 71 


\section{List of Figures}

Figure 1: Trash Load Formula...............................................

Figure 2: Comparing the Bay Area's Trash Load

by Volume (in gallons) and Population.........................................5

Figure 3: Sources of Bay Area Trash............................................6

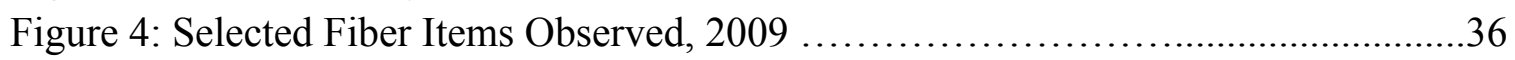

Figure 5: Selected Fiber Items as Percentage of Large Litter

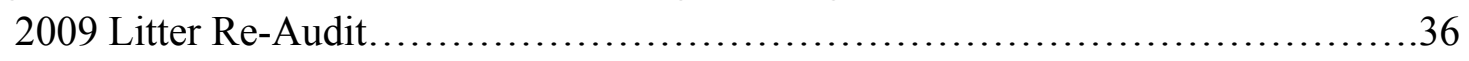

Figure 6: Amount of Items Counted from Bag Sub-Category, 2009..................... 38

Figure 7: Percentage of Bag Sub-Category....................................40

Figure 8: San Francisco Bag Litter: Percentage of Large Litter, 2007-09...............41

Figure 9: Grocery Exit Survey Results of Customer Bag Types, 2008-2014............54

Figure 10: Pharmacy Exit Survey Results of Customer Bag Types, 2008-2014.........58

Figure 11: Store Exit Surveys of Customer Bag Types, 2008-14

(Grocery \& Pharmacy Combined)......................................61

Figure 12: San Jose On-Land Litter Assessment

Proportions of Bag Sub-Category, 2009.......................................64

Figure 13: San Jose On-Land Litter Assessment

Proportions of Bag Sub-Category, 2010.......................................65

Figure 14: San Jose On-Land Litter Assessment

Proportions of Bag Sub-Category, 2012 ......................................66

Figure 15: Stakeholder Perceptions........................................... 80

Figure 16: Impact of Neighboring Cities on Policy Adoption..........................84

Figure 17: Stakeholder Perceptions......................................... 88 


\section{Introduction}

\section{Declaration of Intent}

The City and County of San Francisco implemented the nation's first municipal ordinance regulating the distribution and use of single-use plastic bags. Approved by the Board of Supervisors in April 2007, the Plastic Bag Reduction Ordinance requires "the use of compostable plastic, recyclable paper and or reusable check-out bags by grocery stores and 'chain pharmacies' located within the City and County of San Francisco" (San Francisco Environmental Code 2007, $\S 1701$ ). The ban applied to all retail stores in the city beginning in October 2012. This amendment requires stores to charge a minimum of 10 cents per reusable bag at the point-of-sale (San Francisco Environmental Code 2012, § 1703.5). The ban applied to restaurants in October 2013.

The city adopted this ordinance to contribute to meeting citywide goals of $75 \%$ landfill diversion by 2010 and zero waste by 2020 (San Francisco Achieves...2010). Plastic bags are difficult to recycle and contaminate material processed through the City's recycling and composting programs. Environmental impacts include using 14 million trees and more than 12 million barrels of oil for bags in the U.S. (San Francisco Achieves...2010). Plastic bags have impacted wildlife by contributing to more than 100,000 known deaths to marine life due to entanglement and ingestion (San Francisco Environmental Code 2007, § 1701).

Since 2007, 138 cities and counties in California have adopted 109 ordinances regulating the use of plastic bags, recyclable bags and reusable bags (Californians Against Waste, 2014). This research analyzed municipal plastic bag elimination ordinances' impacts on the cities of San Francisco, San Jose and Palo Alto, as well as the Santa Clara Valley Water District, with data collected reflecting impacts before and after ordinance implementation. 
Specifically, this research addressed the following:

1. How have local ordinances regulating the use of, and distribution of, single-use plastic bags reduced such trash in creeks, waterways, storm drains and public spaces?

2. Compared trends in the purchase and usage of recyclable paper bags and reusable bags before and after implementation. If trash reduction in the form of single-use plastic bags occurred, by what proportion did it drop?

3. Measured the impacts of policy learning and policy diffusion among municipal jurisdictions in the San Francisco Bay Area.

\section{Background}

Within the last seven years various local ordinances in U.S. cities have been adopted and implemented to regulate the distribution and use of plastic bags, specifically, single-use plastic bags that were once ubiquitous in retail stores and consumers' hands. One trillion plastic bags are used worldwide each year, which equates to 300 bags per person (Ocean Crusaders, n.d.). These petroleum-based receptacles have been under regulation in at least 23 countries around the world since the 1990's (Reuse This Bag.com, 2010).

More recently, the plastic bag ban wave has reached municipalities across the United States. Americans use over 100 billion plastic bags each year (The Delaware Valley...2013). In the absence of national legislation, due to the well-organized lobbying strength of the plastics industry, states and cities are addressing this issue one-by-one. Cities in 16 states, including the District of Columbia, have enacted ordinances regulating the use and distribution of single-use plastic bags. Since San Francisco became the first American city to regulate the distribution and use of plastic bags in 2007, cities have increasingly banned the free distribution of plastic bags by retailers. Various ordinances impose minimum charges between five cents and twenty cents per carryout bag_-paper or plastic (Californians Against Waste, 2013). 
In California, 138 cities and counties have adopted 109 ordinances addressing single-use plastic bags (Californians Against Waste 2014). Californians use nineteen billion plastic bags each year at a cost of $\$ 25$ million in state funds to collect and transport the receptacles to landfills (California Legislative Information 2013). Like other forms of trash, plastic bags destroy habitat, harm wildlife, spread diseases and create obstructions and swimming hazards (California State Water Resources Control Board 2013). Plastics represent $60 \%$ of the litter found in local creeks and waterways (California Coastal Commission 2013). Trash on sidewalks and gutters, including plastics, are swept away by rainwaters, which then reach the local storm drain system. These systems then empty into waterways that carry the debris to the ocean (California Coastal Commission 2013). According to this state commission, $90 \%$ of marine debris is plastic. Gusty winds can also carry plastic bags into waterways, while bags and other rubbish are deliberately dumped into creeks and rivers by scofflaws (California State Resources Water Control Board 2013).

Therefore, the San Francisco Bay Regional Water Quality Control Board has instituted a trash reduction plan requiring municipalities with storm water permits to meet specific reduction targets by 2022 . Municipalities had to achieve $40 \%$ trash load reduction by July 1, 2014; 70\% reduction by 2017 and 100\% reduction by 2022 (Wilson, 2013). Trash load as illustrated by Figure 1 is the difference of trash generated subtracted by trash intercepted (Palo Alto 2014c, 9).

\section{Figure 1: Trash Load Formula}

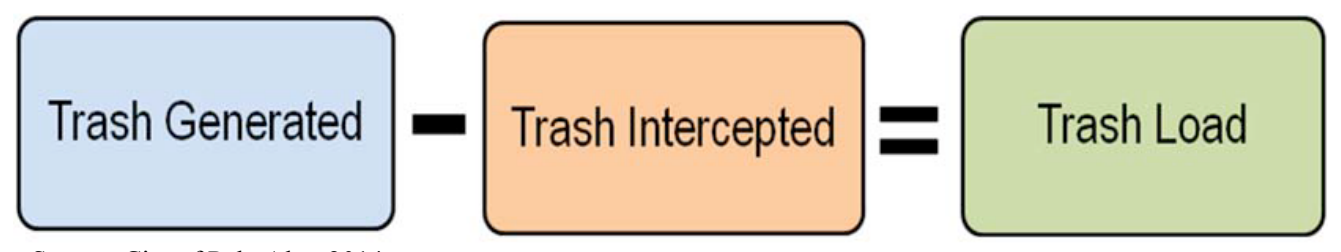

Source: City of Palo Alto, 2014c 
Seventy municipalities discharge storm water into the San Francisco Bay (California State Water Resources Control Board 2013). In addition, the municipalities in the South Bay impact waterways, creeks and rivers over which the Santa Clara Valley Water District has easement rights.

\section{Litter in the Bay Area}

In February 2012, the California Bay Area Storm Water Management Agencies Association (BASMAA) published a report studying the volume of litter flowing into the San Francisco Bay via municipal storm water systems. This report was subsequently published in The San Jose Mercury News. The Menlo Park-based organization commissioned Cascadia Consulting Group of Seattle to conduct the study in preparation for meeting the Regional Water Board's trash reduction targets. Cascadia helps public and private sector clients address environmental issues by improving sustainability with various approaches including storm water pollution prevention. The study measured trash flow by two variables: trash by volume and trash by population. Overall, the study found that 1.36 million gallons of trash travel through storm drains from 76 cities in four bay area counties (Rogers 2012). Those counties include Santa Clara, Alameda, Contra Costa and San Mateo. San Francisco County was not included in the study because its water treatment system collects storm water and sewage together and filters it at treatment facilities (Rogers 2012). The North Bay counties were also omitted from the study because the Regional Water Board's will not apply for "several more years" (Rogers 2012).

The study measured the trash volume in gallons in lieu of pounds because most of the refuse collected in the study, such as plastics was very light (Rogers 2012). Plastic materials such as candy wrappers, chip bags, lids and straws comprised $49 \%$ of the trash while $21 \%$ was paper products and plastic grocery bags represented only $8 \%$ of the total litter collected. Plastic foam 
made up $7 \%$ of the total refuse while cans, bottles and other debris represented the remaining $15 \%$. According to this study, San Jose had the most litter at 168,673 gallons of trash flowing to bay waters. That total was a reflection of two reasons: San Jose had the most land area and largest population of all Bay Area cities during the study. San Jose's population ranked third in California with 969,876 people behind Los Angeles (3,827,172 people) and San Diego (1,315,173 people) (California Department of Finance 2013). Oakland, which had the Bay Area's third largest population at 394,832 people behind San Jose and San Francisco, ranked second with 98,625 gallons of trash (California Department of Finance 2013; Rogers 2012).

Figures 2 and 3 (page 6) illustrate the study's findings in detail.

\section{Figure 2: Comparing the Bay Area's Trash Load by Volume (in gallons) and Population}

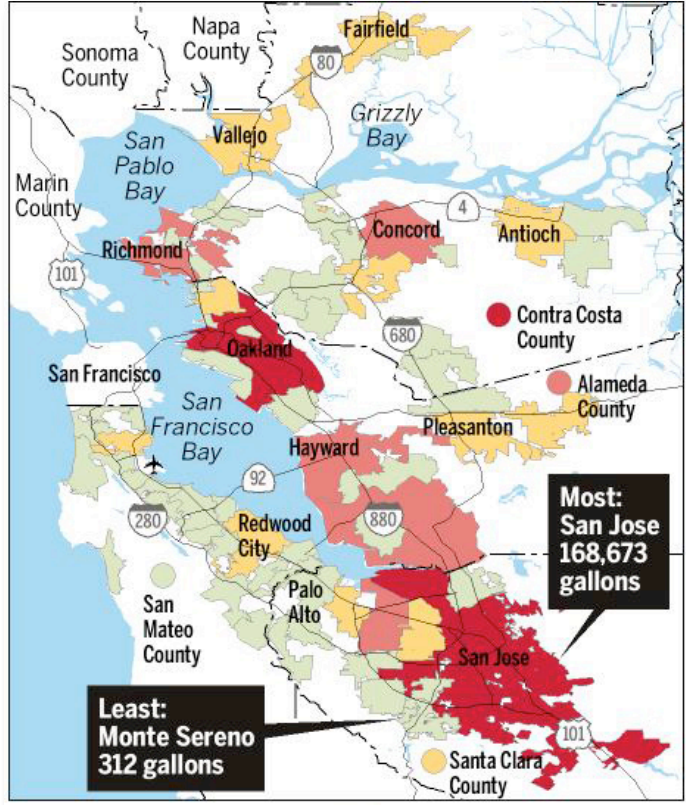

Trash by volume

Estimated annual gallons of trash entering Bay Area creeks via storm drain system

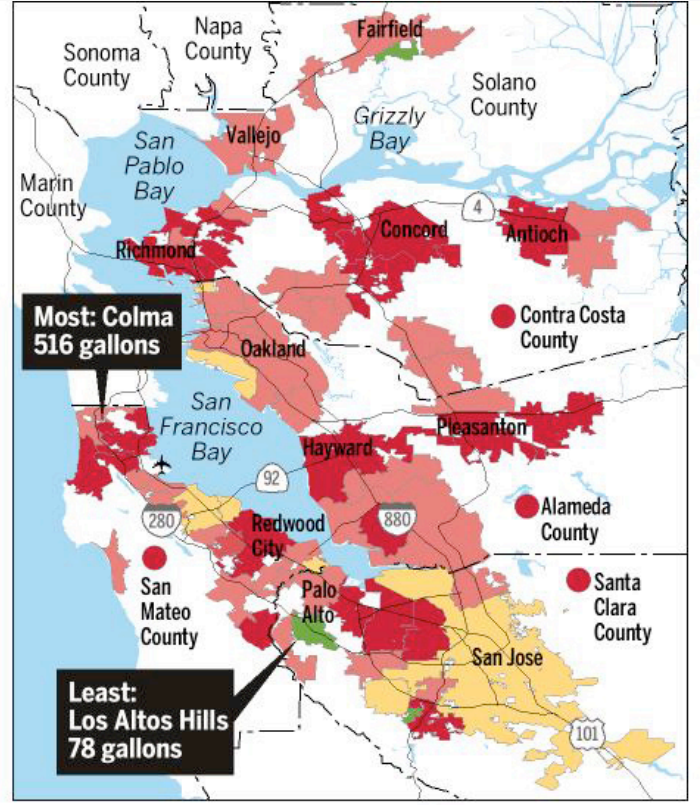

Trash by population

Taking account of a city's population. Estimated annual gallons of trash entering Bay Area creeks via storm drain system per 1,000 people.

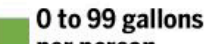

per person 100 to 199 200 to 299 300 or more

NOTE: San Francisco, Sonoma, Marin and Napa counties are excluded from the survey. Source: Bay Area Stormwater Management Agencies Association. Image by istockphoto.com PAI/BAY AREA NEWS GROUP Source: San Jose Mercury News, 2012

However, when measured on a per capita basis, San Jose ranked well below the Bay Area average of 260 gallons of trash per 1,000 people at 176 gallons per 1,000 people (Rogers 2012). 
Yet, when measured on a per capita basis, San Jose ranked well below the Bay Area average of

Figure 3: Sources of Bay Area Trash

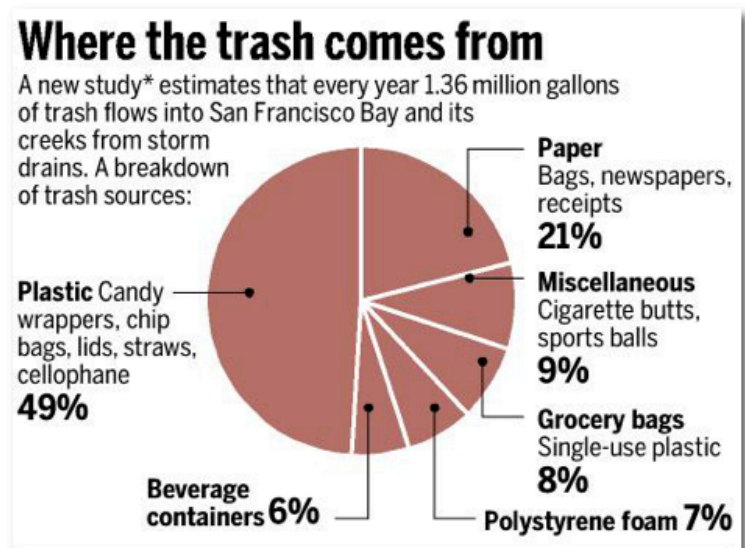

Sources of trash around the Bay Area

Below is the estimated annual gallons of trash entering Bay Area creeks via storm drains. San Jose tops the list by total volume, but when population is factored in, it is in the bottom 10 . The opposite trend is seen in Colma.

\begin{tabular}{|c|c|c|c|}
\hline $\begin{array}{l}\text { Total by city or } \\
\text { unincorporated count }\end{array}$ & $y$ land & $\begin{array}{l}\text { Total by city or unincorp } \\
\text { county land per } 1,000 \text { p }\end{array}$ & $\begin{array}{l}\text { orated } \\
\text { ople }\end{array}$ \\
\hline Rank & Gallons & Gallons pe & 1,000 \\
\hline 1. San Jose & 168,673 & 1. Colma & 516 \\
\hline 2. Oakland & 98,625 & 2. El Cerrito & 510 \\
\hline 3. Contra Costa County & 57,516 & 3. Pittsburg & 423 \\
\hline 4. Fremont & 54,742 & 4. Brisbane & 404 \\
\hline 5. Hayward & 50,761 & 5. Clayton & 395 \\
\hline 6. Alameda County & 45,543 & 6. Martinez & 394 \\
\hline 7. Concord & 44,870 & 7. Richmond & 389 \\
\hline 8. Sunnyvale & 43,318 & 8. Walnut Creek & 369 \\
\hline 9. Richmond & 40,512 & 9. Concord & 366 \\
\hline 10. Santa Clara & 38,359 & 10. Contra Costa County & 357 \\
\hline Bottom 10 & & Bottom 10 & \\
\hline 64. Suisun City & 2,514 & 64. San Jose & 176 \\
\hline 65. Piedmont & 2,362 & 65. Saratoga & 175 \\
\hline 66. Albany & 2,157 & 66. East Palo Alto & 173 \\
\hline 67. Brisbane & 1,750 & 67. San Mateo & 162 \\
\hline 68. Woodside & 1,496 & 68. Los Altos & 150 \\
\hline 69. Atherton & 1,420 & 69. Alameda & 119 \\
\hline 70. Portola Valley & 1,411 & 70. Albany & 116 \\
\hline 71. Colma & 932 & 71. Monte Sereno & 93 \\
\hline 72. Los Altos Hills & 623 & 72. Suisun City & 89 \\
\hline 73. Monte Sereno & 312 & 73. Los Altos Hills & 78 \\
\hline
\end{tabular}

Note: Study excludes San Francisco, Marin, Sonoma and Napa counties

Source: Bay Area Stormwater Management Agencies Association

PAI/BAY AREA NEWS GROUP

Source: San Jose Mercury News, 2012
260 gallons of trash per 1,000 people at 176

gallons per 1,000 people (Rogers 2012). On

the other end of the per capita spectrum was

the City of Colma with 516 gallons of trash

per 1,000 people. However, Colma had a

“"Best Buy, two Home Depots and an auto

row," and a population of 1,444 at the time

of the study (Rogers 2012; California

Department of Finance 2013). The table

entitled Sources of Trash Around the Bay

Area lists a selection of the study's results.

\section{California's Legislators Debate Plastic Bags}

California law attempted to address the

plastic bag issue with Assembly Bill 2449 in

2006. This bill, authored by Assemblyman

Lloyd Levine of San Fernando Valley,

required retailers to establish "recycling

programs" that consist of bins in which

consumers can deposit clean plastic bags for

recycling (California Legislative Information, 2006). The law, which went in to effect in 2007,

also requires retailers to "provide educational materials to encourage the reducing, reusing, and

recycling of plastic carryout bags and to make the materials available to stores" (California 
Legislative Information, 2006). Stores must also submit annual reports indicating the amount of bags the store purchased, how many bags were recycled and which recyclers processed the bags (California Legislative Information, 2006).

The Department of Resources, Recycling and Recovery (Cal Recycle) enforces this law, which the Legislature extended through 2020 when Governor Brown signed SB 1219 in 2012 (Californians Against Waste 2014). However, Cal Recycle did not know how many bags had been recycled because it was unknown how many stores complied with the law (Olson, 2013). Data has not been analyzed since 2009 because resources are not available to fund such research. Cal Recycle is understaffed because manufacturers, retailers and recyclers do not pay any fees to help pay for staff. Therefore, the most recent data from 2009 shows that just $3 \%$ of plastic bags in California were recycled, which was a 1\% increase from 2008 (Olson, 2013). However, according to raw data from the State of California, retailers bought 62.3 million pounds of bags in 2012, which was a 58\% decrease from 107.4 million pounds in 2008 (Olson, 2013).

The California Senate voted down AB 1998 in 2010, which would have prohibited grocery stores and large retailers from distributing plastic bags beginning in 2012, and small retailers from doing so in 2013 (Hindrey, 2010). Authored by Julia Brownley of Santa Monica, this bill sought to repeal the in-store recycling programs established by AB 2449 in 2006 (California Legislative, Information 2010). However, lawmakers from both parties said this bill "was going too far in trying to regulate personal choice" because the bill "would add an extra burden on consumers and businesses at a time when many already are struggling financially" (Hindrey, 2010). The American Chemistry Council, which represented plastic bag manufacturers Dow Chemical and Exxon-Mobil Corporation, spent millions in TV advertising and lobbying costs to defeat the bill (Hindrey, 2013). 
Another attempt to regulate single-use plastic bags failed to pass the state legislature when the Senate voted down AB 40518 to 17 in May 2013. The bill, authored by Senator Alex Padilla, sought to prohibit supermarkets and large retailers from providing single-use plastic bags starting in 2015, with convenience stores and other small retailers doing so a year later. This legislation also required recyclable paper bags and reusable bags to be available at the point-ofsale. This bill required reusable bags to have handles and "be made of cloth or durable plastic" (California Legislative Information, 2013). Reusable bags must be usable a minimum of 125 times and be at least 2.25 millimeters thick (California Legislative Information, 2013). Had this bill become law, Cal Recycle would have been empowered to inspect and audit reusable bag makers and review bags for compliance.

This bill acknowledged that reusable grocery bags might impact public health negatively. Coliform bacteria can accumulate in reusable bags, but washing the bags can eliminate $99.9 \%$ of the bacteria (California Legislative Information, 2013). This legislation referenced a joint study between the University of Pennsylvania and George Mason University about the public heath consequences of reusable bags. This research indicated that emergency room visits caused by $E$. coli infections increased in San Francisco after its bag ban became law in 2007. Neighboring counties did not show such an increase. According to the joint study, other bacterial infections including salmonella increased in San Francisco after the ban's implementation (California Legislative Information, 2013).

\section{Early and Late Adopters of Bag Policies in America}

In 2007, San Francisco became the first American city to adopt legislation prohibiting the use and distribution of single-use plastic bags by grocery stores and chain pharmacies (San Francisco Environment Code $\S 1703,2007)$. A chain pharmacy is described as a licensed 
pharmacy with five locations within city and county limits under the same ownership (San Francisco Environment Code $\S 1702,2007)$. The Plastic Bag Reduction Ordinance (Ordinance No. 33-12) allowed only compostable plastic bags, recyclable paper bags and reusable bags. Any compliant bag was originally offered at no charge at the point-of-sale. Compliant bags include compostable plastic bags that meet standards. Specifically, ASTM Standard D6400 “covers plastics and products made from plastics that are designed to be composted under aerobic conditions in municipal and industrial aerobic composting facilities, where thermophilic conditions are achieved" (ASTM International, 2013). Aerobic conditions refer to the use or requirement of free oxygen that will enable bacteria to breakdown the material in compostable plastic bags. Thermophilic conditions refer to bacteria or other microorganisms that are thermophiles, which require warmer temperatures to grow. Recyclable paper bags are made of $100 \%$ recyclable material, contain load post-consumer product and are not made from old growth trees (San Francisco Environment Code $\S 1702,2007)$. Reusable bags are made from "cloth or durable plastic" with handles that are machine washable. A "durable bag" in this context means a bag that is at least 2.25 millimeters thick (San Francisco Environment Code $\S 1702,2007$ )

The impetus for this ordinance was to help San Francisco reach its waste reduction and landfill diversion targets. City policy required landfill diversion to reach $75 \%$ by 2010 and zero waste by 2020. San Francisco achieved 77\% landfill diversion in August 2010 (San Francisco Achieves...2010). Mayor Ed Lee reported that the City achieved 80\% diversion as of October 2012 (San Francisco Environment Department, 2012).

The ordinance underwent multiple changes in 2012. Amendments included the ordinance applying to all retail stores and food establishments on July 1, 2013 (San Francisco Environment Code $\S 1702,2012$ ). As of October 1, 2012, retailers and food establishments are required to 
charge a minimum ten-cent fee for all compliant bags. The bag charge is to be itemized on customers' receipts (San Francisco Environment Code $\S 1702$, 2012). No food establishment is required to charge patrons for a bag to carry leftover food items from sit-down restaurant dining (San Francisco Environment Code $\S 1703.5,2012$ ). Customers who participate in public assistance programs such as Women, Infants and Children (WIC) and the Supplemental Nutrition Assistance Program (SNAP / Cal Fresh) will not be required to pay the ten-cent bag fee (San Francisco Environment Code $\S 1703.5,2012$ ).

The City of Palo Alto implemented The Retail and Food Service Establishment Checkout Bag Requirements Ordinance (Ordinance No. 5032) on September 18, 2009. The ordinance required grocery stores and supermarkets with facilities of 10,000 square feet or more and gross annual revenues of at least \$2 million to only offer recyclable paper bags or reusable bags (Palo Alto Municipal Code $\S 5.35 .010$ (f), 2009). Seven such grocery stores and supermarkets fell under the ordinance's requirements. Therefore, these establishments offered customers the recyclable bags or the option of a recyclable paper bag or plastic bag upon checkout (Palo Alto Municipal Code $\S 5.35 .020$ (a), 2009). Palo Alto’s ordinance codified the same definitions for recyclable paper bags and reusable bags as San Francisco's ordinance.

This ordinance was amended on May 6, 2013 and implemented on July 1, 2013. Since then, all retail establishments could only offer either a recyclable paper bag or reusable bag to customers for a minimum charge of 10 cents (Palo Alto Municipal Code $\S 5.35 .030,2013$ ). Like San Francisco's law, bag purchases were to be itemized on patrons' receipts. All food service establishments complied with the ordinance as of November 1, 2013 (Palo Alto Municipal Code $\S 5.35 .040,2013)$. Like San Francisco's ban, retail service establishments could not assess the 
ten-cent fee on customers who received WIC and SNAP assistance. However, this exemption expired June 30, 2014 (Palo Alto Municipal Code $\S 2013,5.35 .050$ ).

The City of San Jose implemented the Bring Your Own Bag Ordinance (BYOB) (Ordinance No. 28877) on January 1, 2012. The law says no retail establishment shall distribute single-use plastic bags with handles at the point-of-sale to customers. The law requires retail establishments to offer recyclable and reusable bags as described in the preceding ordinances for a minimum fee of ten-cents (San Jose Municipal Code $\S 9.10 .2020,2012$ ). The ordinance defines a retail establishment as "any commercial establishment that sells perishable or non-perishable goods...” (San Jose Municipal Code $§ 9.10 .2010$ (G), 2012). Furthermore, a retail establishment does not include a "public eating establishment" or "nonprofit charitable reuser" (San Jose Municipal Code $\S 9.10 .2010(\mathrm{G}), 2012)$. A public eating establishment is a restaurant or "take out food" establishment that received at least $90 \%$ of its revenue from prepared food on site (San Jose Municipal Code $\S 9.10 .2020$ (F), 2012). A nonprofit charitable reuser is a "charitable organization as defined by the Internal Revenue Code $((501(\mathrm{c})(3))$ that reuses and recycles donated goods or materials and receives more than $50 \%$ of its revenues from the handling and sale of such goods and materials” (San Jose Municipal Code $\S 9.10 .2010$ (B), 2012).

San Jose retailers had until December 31, 2013, to apply the ten-cent fee. The ten-cent fee remains in place after the City Council voted in September 2013 to not increase the fee to 25 cents following a recommendation from the Transportation and Environment Committee (San Jose 2013b). The increased fee would have taken effect on January 1, 2014, (San Jose 2013a). Like the aforementioned ordinances, this law requires purchased bags to be itemized on customers’ receipts (San Jose Municipal Code $\S 9.10 .2020,2012$ ).

Customers receiving assistance from SNAP and WIC were exempted from paying the 
ten-cent fee for either type of bag until December 31, 2013. Lastly, retailers are required to keep records of the purchase and sale of recyclable paper bags for three years. The records are to be available for review by a city official during business hours (San Jose Municipal Code $\S$ 9.10.2030, 2012).

\section{Literature Review}

\section{Litter Trends at Home and Abroad}

Single-use plastic bags have become a contentious debate around the world as countries large and small, developed and developing, address this issue. The debate centers on reducing, or eliminating, the use of single-use plastic bags due to negative environmental impacts that affect humans and animals. Legislation has been enacted in various countries around the word at various levels of government. Regulations have had varying effects, which depend upon laws' requirements, consumers' attitudes and industry's impact on the process. The trend to regulate single-use plastic bags began in developing countries in the southern hemisphere in the1990's before reaching the U.S. and Europe in the 2000's. In the U.S., cities across the country have enacted ordinances regulating the use and distribution of plastic bags in the absence of federal legislation. As for California, attempts at standardizing plastic bag regulations have failed, leaving cities to address this issue on an ad hoc basis.

Consumers around the world use one trillion single-use plastic bags annually (Clapp and Swanston, 2009). American consumers annually use 100 billion single-use bags, costing retailers \$4 billion a year (Clapp and Swanston, 2009). According to the U.S. EPA, thirty-two million tons of plastic waste was generated in 2011 , representing $12.7 \%$ of the municipal sold waste stream. Of those thirty-two billion tons, only $8 \%$ (2.7 million tons) was recycled. Within that recycled amount, plastic bags were only recycled at a rate of 11\% (US EPA, 2013b). Plastic 
bags are made from petroleum products, specifically high-density polyethylene (HDPE) (Clapp and Swanston, 2009; Lewis, Verghese \& Fitzpatrick, 2010). They are lightweight (usually less than twenty microns thick) and have handles (Lewis, et al., 2010). Plastic bags can take up to 1,000 years to break down. When the bags do eventually break down, they do not biodegrade. Instead, HDPE type bags photo-degrade - meaning that they only break down into smaller pieces, which in some cases, are consumed by animals (Clapp and Swanston 2009, 318).

Still, many bags become litter in public places, but their lightweight and parachute like design enable them to travel effortlessly through the air and in waterways (Clapp and Swanston, 2009). Clapp and Swanston argue, "plastic shopping bags are increasingly seen as environmental hazards that threaten human and animal welfare, rather than benign modern conveniences" $(2009,315)$. Plastic bags threaten public health and safety by serving as "breeding grounds for malaria-carrying mosquitoes, and can clog sewers and storm drains" (Clapp and Swanston 2009, 318). They endanger wildlife such as cows, birds, whales and sea turtles that get entangled in them or mistake the bags for food. As a result, wildlife can eat these small pieces and starve to death (Clapp and Swanston, 2009).

The core issue is plastic bags' impact on sustainability. The United States EPA defines sustainability on its web site as, “...making sure that we have and will continue to have, the water, materials, and resources to protect human health and our environment" (2013a). Governments are addressing sustainability on various fronts, one of which is regulating the use, manufacture and distribution of plastic bags made of HDPE. Governments manage sustainability by applying sustainable development policies. The United Nations defines sustainable development as, "Development which meets the needs of the present without compromising the ability of future generations to meet their own needs" (1987). However, 
various stakeholders, including government, non-governmental organizations, industry, community groups and consumers, each define sustainable development differently (Ritch, Brennan \& MacLeod, 2009). The cause of this varying interpretation is the "complexities associated with aligning individual behavior with this overarching policy of sustainable development" (Ritch, et al. 2009, 168). To achieve sustainability in terms of regulating plastic bags, consumer behavior must be changed.

\section{The Origins of Retail Bag Policies}

Even though some national governments have succeeded in regulating plastic bags, most regulation is borne at the local level for various reasons. Clapp and Swanston argue that an antibag norm has emerged in the last decade. They reference Bernstein's definition of norms to be “ideas and beliefs about what behavior is appropriate" (2001). This norm developed in a south first, north second fashion. In other words, the movement to regulate plastic bags started in developing countries in the southern hemisphere and eventually reached countries in the northern hemisphere (Clapp and Swanston, 2009). This flow of movement is contrary to tradition, when a north-south dynamic is present. For example, issues about hazardous waste, air pollution and endangered species exemplified the north-south movement because developing nations did not have the infrastructure and oversight to enact and promote policy (Clapp and Swanston, 2009).

In the case of plastic bags, it followed the south-first, north-second route in developing nations such as Bangladesh and India during the 1990's. Taiwan addressed carryout plastic bags in the early 2000's (Clapp and Swanston, 2009). Plastic bags caused storm drains and pipes to clog up, exacerbating floodwaters during rainy seasons. Most jurisdictions in India enforced semi-bans, or complete bans, to address the issue. Bangladesh approved an outright ban on all plastic bags following two straight months of floods in 1998 (Clapp and Swanston, 2009). 
Ordinances were passed at the provincial and local levels to protect sacred cows that roamed free. Some cows starved to death because they mistook plastic bags for food prior to the ban. The bags remained lodged in their intestinal tracts, resulting in starvation.

Taiwan currently prohibits the distribution of single-use plastic bags except for use as fast food packaging. Prior to this ban, plastic bags accumulated at landfills or were incinerated with the latter releasing toxic chemicals into the air. Incineration was a common practice until the ban was approved in 2002 (Clapp and Swanston, 2009). Taiwan banned plastic bags from use by retailers in 2002 because they released toxic fumes into the air when they were incinerated, which were a common practice until then. These countries succeeded in banning plastic bags because the bags held little monetary value for recycling, and the plastic industry did not have much of an organized presence to resist these bans in these nations.

As a result of these problems, plastic bag bans emerged in ad hoc initiatives from the bottom-up because people were affected locally. Another reason for the bans includes the fact that recycling and waste collection services are much less established in the global south. Also, recycling plastic bags is not a profitable venture in the global south (Clapp and Swanston, 2009). Finally, the plastic industry is not well established and organized to lobby and influence governments there as well (Clapp and Swanston, 2009).

In countries where the plastic industry is prominent, like the U.S., translating the anti-bag norm into national policy has not been successful (Clapp and Swanston, 2009). For instance, no international consensus, like air pollution, endangered species and water quality, exists to establish standards. According to the Society of the Plastics Industries, the American plastic industry is the third largest industry in the country, employing nearly 900,000 people (SPI, 2012). Other plastics trade organizations like the American Chemistry Council and the American 
Plastics Council are well established, well funded and well organized to challenge national legislation, which is why legislation regulating plastic bags has been virtually nonexistent. Therefore, some states are considering various forms of bans and taxes. Regulation has grown at the local level because the plastic industry is not a significant employer in municipalities where ordinances are adopted and enforced (Clapp and Swanston, 2009).

Internationally, governments have attempted to regulate plastic bag use among consumers by implementing legislation or levies (Ritch, et al. 2009). Plastic bag ordinances finally took hold in Europe when Ireland imposed a $€ 0.15$ surcharge per plastic bag in 2002 (Ritch, et al., 2009). This so-called "Plastax" applied a surcharge to all plastic bags used "at the point-of-sale in supermarkets, shops, service stations and all sale outlets" (Ritch et al., 2009). As a result, plastic bag use declined significantly by $94 \%$ and generated $€ 3.5$ billion in revenue within a year of implementation (Ritch, et al., 2009). Ireland's so-called "plastax" is now $€ 0.33$ (Rosenthal, 2008). Ireland's measure is an example of a redistributive policy, which is strongly sanctioned and generally targeted. Irish consumers embraced reusable bags made of cloth and wheeled carts to transport their purchases because they did not want to pay the tax (Ritch, et al., 2009). Ultimately, Ritch, Brennan and MacLeod conclude that it is "imperative to better [align] production and consumption patterns in pursuit of sustainable development," which Ireland has achieved and many American cities want to achieve $(2019,173)$.

\section{Environmental Impacts of Paper and Plastic Bags}

Lewis, Verghese and Fitzpatrick (2010) study life cycle assessment (LCA) methodology. LCA is a "systematic way of calculating the inputs...outputs... and potential environmental impacts of a product or service throughout its life cycle" (Lewis et al., 2010, 147). Materials, energy and water represent inputs while solid, waterborne and gaseous wastes represent outputs 
(Lewis et al., 2010). This process provides "quantifiable results that reveal causes of environmental impact and points in the supply chain where changes can be made to reduce them" (Lewis et al., 2010, 147). Results depend upon assumptions drawn from the product system, including how the product is made, consumed and disposed of (Lewis et al, 2010).

The first major study applying the LCA method occurred in the United States. The study by Franklin Associates in 1990 compared the impact of single-use plastic bags and polyethylene (petroleum based) bags. This study revealed that plastic bags had lower environmental impacts than paper bags (Lewis et al., 2010). The results are as follows:

1. Plastic bags use $20 \%-40 \%$ less energy than paper bags at a zero recycling rate.

2. Plastic bags contribute $70-80 \%$ less solid waste than paper bags

3. Atmospheric emissions for plastic bags were $63-73 \%$ lower than paper bags

4. At a zero recycling rate plastic bags contributed over $90 \%$ less waterborne emissions than paper bags

More recent research using the LCA method in Australia compared single-use bags with alternatives such as paper bags, reusable bags and biodegradable bags. Each sample was measured for its impact on global warming, smog creation, the amount of nutrients it released into waterways, land use, solid waste, fossil fuels and minerals. The study concluded that reusable bags resulted in lower environmental impacts than single-use bags (Lewis et al., 2010). However, reusable bags needed to be used at least 50 times to achieve the low impact rating because polypropylene (PP) and polyethylene terepthalate (PET) bags require more energy to manufacture (Lewis et al., 2010). This study reinforced the Franklin Associates conclusions that paper bags have a higher environmental impact than plastic bags. However, paper bags have a positive reputation because they are recyclable, degradable and have minimal impacts on litter 
(Lewis et al. 2010). The study did not address each bag type's impact on either wildlife or litter creation.

Lewis et al. conclude that decisions regarding the sustainability of plastic bags and alternative bags should consider each option's environmental impacts (2010). The authors ask if government leaders and retailers should implement measures to reduce risks to either wildlife or global warming. Therefore, stakeholders' values and priorities should be clearly understood.

Ultimately, the authors conclude that international consensus does not exist as to what constitutes sustainable packaging. Sustainable packaging must optimize functionality to increase its effectiveness and be more efficient by using fewer resources. More innovative packaging should minimize wastes and emissions throughout its life (Lewis et al., 2010). The authors further state that a final decision must be reached by evaluating certain criteria such as functionality, cost and “environmental priorities" (Lewis et al., 2010, 153).

\section{Policy Diffusion}

In the absence of national and state legislation regarding single-use bag ordinances, local governments, particularly cities, usually learn from the policy experiences of other local jurisdictions. This observation is one component of the process of policy diffusion, which is the “spread...[or] movement of policy across jurisdictional boundaries" (Karch 2007, 56). Policy diffusion begins with policy innovation, which occurs when a government at any level adopts a new policy (Shipan and Volden 2008). Innovation can originate from within the political environment "such as when interest groups within a state push for adoption of a new policy, or when electoral and institutional forces within a legislature affect the likelihood of adoption" (Shipan and Volden 2008, 841). Policy diffusion is different from adoption, which is the decision by a governing body "to establish policy in a particular jurisdiction" (Karch 2007, 56). Examples 
of notable policy diffusion are same-sex marriage, education reform, abortion and the death penalty, which are state issues as opposed to municipal issues. Besides plastic bag ordinances, anti-smoking laws are a notable example of policy diffusion at the local level.

University of Minnesota Associate Professor Andrew Karch, Ph. D., analyzes the elements that impact policy diffusion from state-to-state in America while Shipan and Volden analyze policy diffusion among cities. While Karch's research focuses on policy diffusion among the states, which has been the focus of diffusion research since the 1960's, some of his research components are applicable to diffusion at the local level. Karch addresses three questions in his research:

\section{Why does policy diffusion occur?}

2. Which political actors or forces facilitate diffusion?

3. What is being diffused?

Karch identifies four reasons explaining why diffusion occurs: geographic proximity, imitation, emulation and competition.

\section{Policy Diffusion Among the States}

Since the 1960 's, political scientists have relied on geographic proximity as the key reason for policy spreading among the states and other jurisdictions. According to Karch, political science scholars have supported the geographic proximity conclusion because they assume the policies that neighboring states, and for the purposes of this research, cities have enacted will influence nearby states (and cities) to adopt the same policy (2007). Karch argues three reasons that these assumptions have persisted. The communication networks shared between neighboring states allow quick access to government leaders. Overlapping media 
markets inform citizens and decision makers in nearby states about policy elsewhere. Lastly, government officials may be interested in "[using] nearby states as policy models because they are likely to be culturally and demographically similar to their own states" (Karch 57, 2007).

However, the academic research presented in this document is concerned with policy diffusion among cities in terms of plastic bag ordinances. Some cities in Santa Clara County have implemented such ordinances enacted by early adopters like San Francisco and Palo Alto. Recent scholarly work discredits geographic proximity as the driving force behind diffusion among the states because of modern communication and transportation technology, which makes acquiring policy-related information from across the country quick and easy. Karch cites empirical research by Mooney concluding that diffusion on a regional level is "not consistently positive" $(58,2007)$. Overall, most diffusion studies fail to segregate the various forces that influence a geographic pattern of diffusion (Karch 2007).

Karch identifies imitation as the second reason why policy diffusion occurs. He says, “...a policy may diffuse because officials believe that they share a policy-relevant characteristic" such as reducing waste, with another jurisdiction that has implemented it, and as a result, the decision makers considering adoption believe they should do the same (Karch 2007). Researchers who have studied diffusion through the imitation lens argue that "ideological and resource similarities" are requirements for jurisdictions to learn from each other (Karch 2007, 59). Ideological similarities among local cities regarding eliminating single-use carryout plastic bags are that they pose an environmental threat to humans and wildlife by polluting waterways and bodies of water. Production and transportation of single-use plastic bags release greenhouse gases such as carbon monoxide, which negatively impact air quality. Resource similarities include city staff to conduct litter audits, as well as using materials and 
media to promote and educate stakeholders of plastic bag ordinances. Overall, Karch concludes policies reach other jurisdictions because policymakers "imitate their colleagues who operate in similar political environments" (Karch 2007, 60).

Emulation is the third reason identified by Karch to impact policy diffusion. Emulation occurs when lawmakers try to recreate a policy in their jurisdiction as a result of its success elsewhere. Officials adopt the successful policy because they believe it will help them achieve meaningful policy goals and objectives. This belief is driven by a policy's perceived success by the decision-makers considering the policy (Karch 2007). For example, more recent local adopters of plastic bag ordinances, such as Cupertino and Campbell, have noticed the success of San Jose's Bring Your Own Bag (BYOB) Ordinance. Cupertino and Campbell adopted plastic bag ordinances in March and July of 2013 respectively (Californians Against Waste 2014). These ordinances were enacted prior to the San Jose City Council's decision in September 2013 to not increase the minimum bag fee charged by retailers from 10 cents to 25 cents because the ordinance had successfully changed norms among consumers to reuse bags for retail purchases and reduced litter in public spaces (San Jose 2013b).

While a successful policy is what causes policy emulation in other jurisdictions, there are considerable challenges to applying emulation as a reason for diffusion. Karch argues that it is very difficult to judge "public policies...in the political world" (Karch 2007, 61). The reason being is that "background conditions change, important actors enter and leave the scene, and values are not always clear and [congruent]" (Karch 2007, 61). Even if explicit and agreed guidelines existed, policy decisions are impacted by political influences (Karch 2007). Over time officials may either change their focus in relation to policy goals or change the criteria by which 
they evaluate a policy's success. Therefore, public policies must meet both political and meaningful policy goals to make diffusions by emulation possible (Karch 2007).

The last reason Karch identifies as impacting policy diffusion is competition. Under this lens, policy diffuses because decision-makers believe that not adopting policy will result in a competitive disadvantage. Furthermore, decision-makers in a particular jurisdiction may feel pressure to keep up with their colleagues in other jurisdictions (Karch 2007). For example, state governments compete by "racing to the top" or "racing to the bottom" depending on the policy. Specifically, states race to the top by approving policy to attract businesses to further their economic development objectives. This "race to the top" is exemplified when citizens and businesses move to places that offer the most favorable ratio of taxes paid to services received (Karch 2007). The race to the bottom occurs when states choose to be less attractive to an undesirable group. This "race" occurs when states adopt less generous welfare policies to limit the amount of welfare-dependent individuals, for instance (Karch 2007).

A "race to the top" at the local level occurs when a company seeks a location to build its facilities. For example, Local officials may decide whether or not to approve construction of facilities to house a business' research and development operations. If decision makers vote down the proposal, for example, another neighboring city may approve construction, thus garnering tax revenue for the other city as well as revenue for support businesses in that city. With regard to plastic bag ordinances, officials may feel pressure to not approve such a ban for fear of backlash from the industrial sector interest groups in their cities. However, such a scenario is not likely prevalent due to cities becoming compliant with the State Water Boards' storm water permit policy to eliminate litter in waterways by 2022. 
Karch identifies three political forces that impact policy diffusion: national organizations, policy entrepreneurs and national government intervention. These three forces, or actors, have geographic reach, which allows them to spread policy-related information across state lines. National organizations like interest groups, professional associations and think tanks place high priority on informing policymakers of policy-relevant information (Karch 2007). Interest groups participate in diffusion to decision makers by taking distinct positions on particular policies. Karch cites Thomas and Hrebenar's work that interest groups cause policy diffusion due to their strong relations between their national offices, and state and local offices (Karch 2007). Professional associations, like interest groups, inform decision makers of policy-relevant information without less distinct political stances on policy issues (Karch 2007). National organizations, like the American Chemistry Council, which represent the plastic industry, have impacted the development of local bag ordinances across the country.

Policy entrepreneurs are actively engaged individuals who "either operate or have professional connections in [multiple states]" helping them expedite policy diffusion (Karch 2007, 66). Furthermore, policy entrepreneurs are willing to use "“their own personal resources of expertise, persistence, and skill to achieve certain policies they favor"' (Karch 2007, 66). Policy entrepreneurs can be elected leaders, executive agency officials or private citizens. Their ability to network in many states enables policy entrepreneurs to learn about public policies' impacts elsewhere (Karch 2007). Only limited research on this aspect of policy diffusion is available due to the challenges of measuring entrepreneurial activity (Karch 2007).

Diffusion by national government intervention is a vertical process in a top-down flow. National government can influence state and local governments by either approving or withholding federal funding for programs like Medicare and Medicaid. The federal government 
can also require compliance with state and local governments when dispensing funding in the form of block grants. On the other hand, the federal government can affect public policy that is unrelated to financial matters. For example, as Karch (2007) states, national elections, Supreme Court decisions and national public opinion can also affect policy diffusion. Overall, federal government decisions affect policy making at all levels due to agenda setting (Karch 2007). However, with the absence of national legislation regarding the regulation of single-use carryout bags, intervention by the federal government is not a factor on this policy area at this time.

As a policy diffuses to other jurisdictions, government officials and decision-makers have time to monitor the consequences of a particular policy. Based on a policy's application and reaction from stakeholders, decision makers in other jurisdictions can decide how, and if, to implement that policy in their municipality. Later adopters' actions can indicate if a policy is diffusing due to emulation, imitation, competition or another factor (Karch 2007). Karch cites research by Clark and French that examines, "whether later adopters establish more or less expansive policies than leaders or whether they simply practice wholesale borrowing" (Karch 2007, 70). Limited study on this aspect has shown that later adopters install sweeping versions of a policy (Karch 2007). However, Karch posits that later adopters may enact more limited policies if early adopters encounter administrative challenges and backlash from stakeholders (2007).

\section{Policy Diffusion Among the Cities}

Political science and public policy professors Charles Shipan and Craig Volden identify and apply four policy diffusion mechanisms that affect policy development at the municipal level. Specifically, Shipan and Volden (2008) attempt to uncover why these mechanisms cause anti-smoking policies to spread across city governments between 1975 and 2000. Anti-smoking policies included smoking restrictions in government buildings and restaurants, as well as 
restricting youth access to tobacco products. The researchers' goal is to better understand the political benefits driving policy decisions. The four mechanisms are learning, economic competition, imitation and coercion. These mechanisms that Shipan and Volden argue create "laboratories of democracy" at the subnational level "where they experiment with different policies and learning from one another" $(2008,840)$. The impact analysis of this work looks to see what diffusion mechanisms influence adoption of plastic bag bans and reusable bag ordinances.

Learning in the laboratories of democracy occurs when policymakers study the policy adoption and implementation experiences of other jurisdictions. Decision makers ascertain the politics and externalities of policy adoption elsewhere to determine if a policy is successful (Shipan \& Volden 2008). The best-case scenario for learning occurs when multiple governments try a policy, especially when policies impact larger populations (Shipan and Volden 2008). Shipan and Volden's research demonstrates cities are more likely to adopt policies when a larger proportion of citizens in other cities within the state are covered by a homogeneous law (2008).

Like Karch's research, Shipan and Volden identify competition as a method of diffusion - specifically economic competition. Policymakers weigh the economic effects of adoption and non-adoption of a particular policy by other governments. Specifically, decision makers compare a policy's positive and negative economic spillovers. A spillover is the unexpected consequence or byproduct of a decision (Shipan \& Volden 2008). For example, a city is less likely to adopt a policy that is not adopted by neighboring cities due to negative economic spillovers. On the contrary, a city is more likely to adopt a policy with positive economic spillovers such as creating uniformity like reusable bag ordinances (Shipan \& Volden 2008). Outflow is the major reason decision makers do not adopt policy. Outflow occurs when a 
city adopts a policy its municipal neighbors have not adopted resulting in negative economic consequences for the adopting city (Shipan \& Volden 2008). In other words, residents may spend their money in neighboring cities without anti-smoking laws so they can smoke in restaurants, for example. Shipan and Volden's findings indicate that cities are hesitant to adopt anti-smoking policies until their neighbors act. For example, "a one-standard deviation increase in the outflow variable...is associated with a 33\% drop in the odds of adoption..." (Shipan \& Volden 2008, 849). Together, learning and economic competition have longer lasting effects according to Shipan and Volden's work (2008).

Imitation is the inverse of learning. While learning analyzes the action a government took (i.e., the adopted policy), imitation focuses on the actor (i.e., another government that is adopting a policy). Learning analyzes how a policy was adopted, its effectiveness and its political consequences. In contrast, imitation asks the following questions: "What did that government do and how can we appear to be the same?" (Shipan and Volden 2008, 842). According to Shipan and Volden, larger, wealthier and more cosmopolitan cities have been the traditional policy innovators that small cities aspire to be like (2008). As a result, smaller cities tend to adopt similar policies to keep citizens and businesses from leaving for larger cities. Ultimately, leaders in smaller cities "want their communities to be favorably viewed" like the leader cities to increase their appeal and profile (Shipan \& Volden 2008). Shipan and Volden's (2008) study illustrates that smaller cities are more likely to adopt anti-smoking laws that have been enacted by the nearest big city. Their study further shows that imitating a policy has short-lived impacts (Shipan \& Volden 2008).

The last mechanism is coercion, which is more among country-to-country relationships in regarding international trade and economic sanctions. Domestically speaking, vertical coercion 
exists in a top-down fashion in the form of federal block grants that require states and cities to adopt federal policies in exchange for funding. Cities are also subject to coercion from state governments because they are "creatures of the state"... with no constitutional sovereignty. Therefore, state governments can pass preemptive policies to prevent city actions that conflict with state policies. This approach greatly reduces cities from passing lesser laws (Shipan \& Volden 2008). Therefore, Shipan and Volden's study reflects that a state anti-smoking law results in a $26 \%$ decline in probability of an anti-smoking law being adopted at the municipal level (2008). In the case of a preemptive state law, the probability of cities adopting antismoking laws drops by $94 \%$ (Shipan \& Volden 2008).

In summary, Shipan and Volden's research shows policy diffusion acts differently in different cities - large and small. For example, "larger cities are better able to learn from others, less susceptible to economic competition, less likely to engage in imitation, and less vulnerable to coercion" (Shipan \& Volden 2008, 853). Also, policies affect different populations, which indicate imitation would not benefit some cities. Smaller cities are more concerned with economic competition and economic spillovers than larger cities. Regardless of population size, cities large and small are at the mercy of coercion by state governments.

\section{Methodology}

This research employed an outcome evaluation "to measure the degree of consistency between [legislative] intent and outputs" as regulated by reusable bag ordinances in the cities of San Jose, Palo Alto and San Francisco. (Sylvia \& Sylvia, 2004, 117). Specifically, a time-series design analysis was used to measure variables prior to and after implementation of the ordinances. Time-series analyses allowed observations to be gathered in retrospect due to the availability of records and statistics (Sylvia \& Sylvia, 2004). This analysis measured the impacts 
of reusable bag ordinances on the aforementioned cities regarding reduction of single-use plastic bags found in creeks, waterways, storm drains and public areas. Other impacts that were measured included the purchase and use of reusable bags and recycled paper bags by consumers at retail outlets. This data is available at retail outlets that are required to keep such records, which are reviewable by the applicable jurisdiction. Data from the year prior to implementation of each ordinance served as baseline data. Baseline data consisted of the same variables previously mentioned. The baseline data was compared with the same variables after the ordinance took affect. Each variable was compared on separate line graphs for ease of comprehension.

While these cities' ordinances defined terms related to bag types, consumers and retailers; no such definitions for a creek, waterway or storm drain were included. Despite researching state and federal resources, no definitions were found for these same terms. As a result, the researcher applied Merriam-Webster's definitions for these terms. A creek is defined as, "a natural stream of water normally smaller than and often tributary to a river" (2015a). A waterway is considered deep and wide enough to enable boats and ships to travel through (Merriam-Webster 2015c). As for storm drains, they "carry wastewater other than sewage from buildings to storm sewers" (Merriam-Webster 2015b). Storm drains also carry water resulting from precipitation originating on surfaces to a storm sewer (U.S. EPA 2015).

San Francisco implemented its Plastic Bag Reduction Ordinance

(Ordinance 81-07) in March 2007. Palo Alto instituted its Disposable Checkout Bag Ordinance (Ordinance 5032) in September 2009, while San Jose's Bring Your Own Bag Ordinance (Ordinance 28877) became law on January 1, 2012. Since then, the three cities gathered data at different times after implementation of their respective ordinances. The City of San Francisco's 
Environment Department released its Streets Litter Re-Audit in 2009. This audit was prepared by two firms: HDR / Brown, Vence and Associates, Inc. (BVA) and Canada-based MGM Management. HDR / BVA is a multi-national company that serves as an engineering and management consulting firm specializing in solid waste management, planning and energy management consulting. HDR / BVA contracted MGM Management; an environmental consulting firm that provides environmental technical analysis including litter audits.

The City of Palo Alto's Environmental Compliance Division collected litter and other pollutant data and published its findings last spring in the Clean Bay Pollution Prevention Plan 2014. This report explained "the pollutant priorities, [including trash], sources of those pollutants, pollution prevention progress made in 2013, and the tentative plan for the coming year" (Palo Alto 2014, 2). Additional data from Palo Alto included store exit surveys of bag usage trends among consumers performed by city staff between 2008 and 2014. Survey results from retail facilities of 10,000 square feet or greater collected by city staff members between January and March 2014 are also presented. Specifically, retailers were surveyed about bag types and fees; reusable and paper bag sales data; bag material and label requirements, as well as challenges retailers encountered during implementation in 2013 (Palo Alto 2014b).

San Jose collected litter data and consumer use trend data in 2012 and 2013. This information was presented in multiple staff reports submitted to the City Council in 2012 and 2013. The secondary data demonstrated the extent of the ordinances' impacts on each jurisdiction's trash reduction goals. In other words, did these ordinances achieve their legislative intent based on the outcomes presented in this study?

Data from the following sources was analyzed to gauge the impacts of the ordinances on the variables: The Department of Environmental Services (San Jose), The Department of the 
Environment (San Francisco) and The Planning and Community Environment Department (Palo Alto). Time-series data from these three cities was analyzed to mitigate history as a threat to validity per Sylvia and Sylvia (2004). Sylvia \& Sylvia say, "History can be controlled by the introduction of additional time-series data from.... a neighboring city, or cities of comparable size and demographics" (155). Despite San Jose, San Francisco and Palo Alto having different populations and demographics, these cities' ordinances have been established long enough with available data to measure regulatory impacts before and after implementation unlike later adopting cities. However, the researcher interpreted secondary data with caution because it can be difficult connecting outcome changes solely to changes in policy.

Representatives from the three previously mentioned departments were invited to be potential survey subjects. These and other potential survey participants were asked to respond to questions regarding the implementation and impacts caused by these ordinances. Impacts included environmental changes, such as single-use plastic bag litter reduction, consumer bag usage trends, and litter abatement costs. Questions also measured how these jurisdictions made progress toward trash reduction targets in storm drains as mandated by the California State Water Resources Control Board (CASWRCB). Locally, the San Francisco Water Board required trash flow to storm drains be reduced by $40 \%$ in 2014 with further reductions of $70 \%$ in 2017 and 100\% in 2022 (CA State Water Resources Control Board 2013a). Bag usage trends were considered as the amount of recyclable paper bags versus the amount of reusable bags used by consumers, which was an assumption made by the researcher. Recyclable paper bags are defined as containing no old growth fiber, $100 \%$ recyclable and include a minimum of $40 \%$ postconsumer recycled content (Palo Alto $§ 5.35 .010$ (d), 2009). Old growth fiber is material from old trees in their later stages of development... with the majority found only in the highest reaches of 
the mountains, wilderness reserves in the lower alpine zone, or in steep inaccessible stream canyons" (Sierra Forest Legacy, 2012). Reusable bags are defined as having a capacity of up to or beyond 15 liters and meet Eco Logo ATP-001 standards (Palo Alto §5.35.010 (f), 2009).

This research also employed a quantitative research design in the form of voluntary surveys to identify trends, attitudes and opinions regarding policy diffusion and policy learning. Specifically, survey responses from the sample group enabled the researcher to identify trends to make generalizations and inferences about the population of the Bay Area's municipal public administrators who are involved with implementing plastic bag ordinances and monitoring their impacts (Creswell 2003). The sample group included public administrators chosen from cities and counties in the nine-county San Francisco Bay Area with and without plastic bag ordinances. This data helped the researcher generalize about policy diffusion and policy learning in Bay Area communities. This primary data reflected a single-stage sampling approach because the researcher had access to the names of the intended survey participants (Creswell 2003).

This research employed a web-based survey. According to Creswell (2003), a web-based survey approach offers the following benefits:

1. Economy of design

2. Rapid turnaround in data collection

3. Identifying attributes of a large population from a sample group

Other benefits to web-based surveys included adding definitions and explanations in context to clarify survey questions, as well as the use of multimedia tools as needed. The key drawback to web-based surveys is that only computer literate individuals with Internet access were able 
participate. However, the individuals in the sample size are all computer literate and have constant access to the Internet as required by their jobs. This survey utilized a cross-sectional approach because the sample group participants only needed to answer the questions in one session. Data was collected as it became available, however. Participants' names and job titles were kept confidential and anonymous. The names of all invitees and respondents, as well as their department and employer names were not released in any portion of this study.

The researcher did not ask any personal questions, as the public administrators themselves were not the subjects of this study. Instead, the information respondents provided related to ordinances' legislative intent, plastic bag litter, consumer trends and policy diffusion were analyzed in this study. Public Administrators' personal identifiable information was irrelevant to this study and would have required further scrutiny by the Human Subjects Institutional Research Board (IRB) at San Jose State University. Professional input increased the credibility of this research because it provided additional information that can yield more insight to the research question. The sample procedure utilized the single-stage method because "the researcher [had] access to names in the population and [sampled] the people or other elements directly" (Creswell, 2003, 156). The sample group was stratified into two groups: adopters and non-adopters. Adopters represented cities with a retail bag ordinance and non-adopters represented cities without a retail bag ordinance.

No research related interaction with the public administrators occurred until after the Institutional Research Board granted proper clearance. In November 2014, the San Jose State University IRB determined this study's data instruments (survey questions) were exempted from further vetting as they neither included nor sought respondents' personal identifiable information. The guidelines for conducting a research interview as described by Bardach were 
available for consultation in the event of follow-up interviews (2012, 94-104). Survey results were made available to respondents who requested to review them. All data instruments are attached in the appendix of this document.

\section{Findings}

\section{San Francisco}

The City of San Francisco released its Streets Litter Re-Audit in September 2009. This audit was conducted in partnership between HDR / BVA and MGM Management from April 20th to May 5th, 2009. This audit follows two previous studies conducted during the same time period in 2007 and 2008 (San Francisco Streets Litter... 2009). The 2009 audit presents the most recent available data based on large and small litter observations. Representatives from the San Francisco Department of the Environment (SFDE) said that no further litter studies are planned for the future (Phone Interview 2014). SFDE does not write, track, or publish reports, nor enforce the Plastic Bag Reduction Ordinance because SFDE is not an enforcement agency (Phone Interview 2014). SFDE has limited staffing and resources (Phone Interview 2014).

The 2009 study classifies two types of litter: large litter and small litter. The former is considered as "items over four square inches in size" while the latter is considered as "items less than four square inches..." (San Francisco Streets Litter... 2009, 2). These two categories were further divided into 84 sub-categories of large litter and 16 sub-categories of small litter (San Francisco Streets Litter... 2009). Plastic retail bags represent a large litter sub-category based on the aforementioned description. In sum, auditors catalogued 4,488 large litter items at 132 randomly selected sites within San Francisco's city limits during the audit period.

Over 130 potential sites were originally considered for the study, but six sites were not audited due to safety and logistical concerns such as roadway medians, for example. Auditors compared 
these results to data collected in 2007 and 2008. Data collected in 2007, which is the year San Francisco's Board of Supervisors implemented the Plastic Bag Reduction Ordinance serve as the baseline data. In 2007, auditors observed 3,812 pieces of large litter equaling an average of over 36 large litter items per site at 105 sites. In 2008, auditors surveyed the same 105 sites, as well as 25 additional sites selected randomly to increase the sample size of audited sites (San Francisco Streets Litter... 2009). Figures from the 2008 audit revealed that 3,978 large litter pieces were observed equaling an average of 30.6 items observed per site at 130 sites. These figures equate to a 16\% decrease compared to the baseline data (San Francisco Streets Litter... 2009). Lastly, 4,488 large litter items were collected in 2009. Table 1 lists the average amount of large litter items collected during each audit period.

\section{Table 1: Comparison of Large Litter Data Results (2007-2009)}

\begin{tabular}{||l|l|l||}
\hline \hline $\mathbf{2 0 0 9}$ & $\mathbf{2 0 0 8}$ & $\mathbf{2 0 0 7}$ \\
\hline Sites & Sites & Sites \\
\hline 132 & 130 & 105 \\
\hline Items / Site & Items / Site & Items / Site \\
\hline 34.0 & 30.6 & 36.3 \\
\hline \hline
\end{tabular}

Source: Streets Litter Re-Audit, Department of the Environment City of San Francisco, 2009

The most common large litter items observed by auditors in 2009 included miscellaneous paper, non-branded napkins, printed materials, candy bar wrappers, miscellaneous plastics and tobacco products (San Francisco Streets Litter... 2009). Audit figures from 2009 indicate an average of 34 large litter items per site, which is an $11 \%$ increase compared to 2008 data (San Francisco Streets Litter... 2009). However, the 2009 results show a decrease in the average amount of large litter items per site of more than six percent (6.4\%) when compared to the 2007's baseline mean of 36.3 large litter items per site. With no subsequent litter audits since 2009, an assumption can be made about the trend of large litter items per site. Specifically, one 
can assume that while the average amount of large litter items per site may vary year to year, an overall declining trend in this variable on a long-term basis is possible as more retailers and restaurateurs have been subject to San Francisco's Plastic Bag Reduction Ordinance regulating the free distribution of various types of receptacles.

Miscellaneous paper represents the largest proportion of large litter items observed in 2009 at 12.3\% (552 pieces) (San Francisco Streets Litter... 2009). This amount represents a 42\% increase in this large litter sub-category compared to 2008 (319 pieces), but a $3.2 \%$ decrease compared to the 570 items observed in 2007 (San Francisco Streets Litter... 2009). In 2009, auditors counted 189.5 items in the Bags sub-category, which included both paper and plastic bags. This total represented $4.22 \%$ of the entire large litter category (San Francisco Streets Litter... 2009). Plastic bags comprised (107 items) 56.5\% of the Bags sub-category while paper bags comprised the balance of this sub-category (43.5\%). By comparison, plastic bags comprised 73\% of the Bags sub-category in 2008 (San Francisco Streets Litter...2009, 37). Table 2 on page 36 and Figures 4 (page 36) and 5 (page 37) illustrate litter audit results of selected fiber items observed during the 2009 re-audit.

Table 2: All Paper \& Fiber Litter - 2009 Audit

\begin{tabular}{|c|c|c|}
\hline Select Fiber Observed & $\begin{array}{l}\text { Items } \\
\text { Observed }\end{array}$ & $\begin{array}{l}\text { \% Of Total } \\
\text { Large Litter }\end{array}$ \\
\hline Printed Materials & 557.5 & $12.4 \%$ \\
\hline Miscellaneous Paper & 552.5 & $12.3 \%$ \\
\hline Napkins (all types) & 479 & $10.7 \%$ \\
\hline Fiber Packaging (including bags / wraps) & 432.5 & $9.6 \%$ \\
\hline Miscellaneous Cardboard & 34.5 & $0.8 \%$ \\
\hline Miscellaneous Paperboard & 6 & $0.1 \%$ \\
\hline Total & 2,062 & $45.9 \%$ \\
\hline
\end{tabular}

Source: Streets Litter Re-Audit, Department of the Environment City of San Francisco, 2009 
Figure 4: Selected Fiber Items Observed, 2009

\section{Selected Fiber Items Observered}

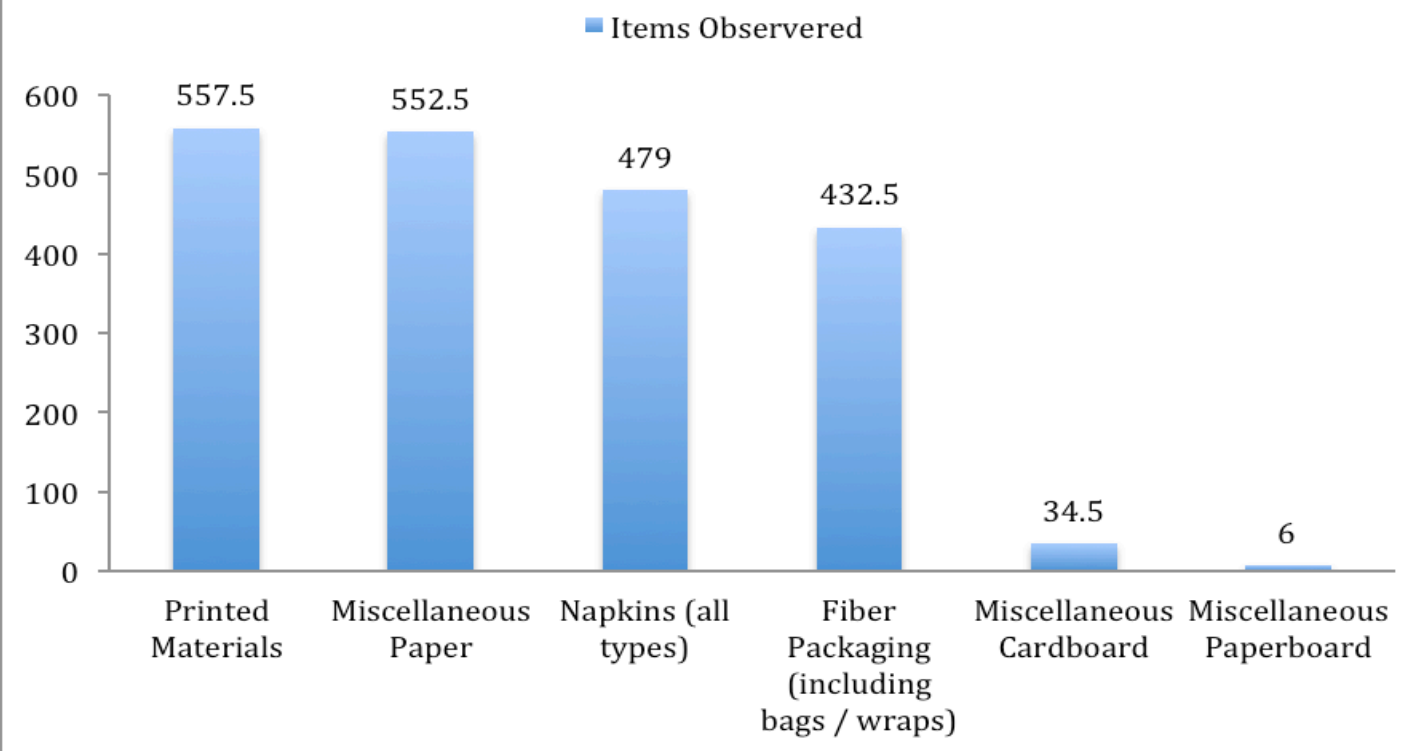

Source: Streets Litter Re-Audit, Department of the Environment City of San Francisco, 2009

Figure 5: Selected Fiber Items as Percentage of Large Litter, 2009

\section{\% of Total Large Litter}

ㅍ of Total Large Litter

$12.4 \%$

$12.3 \%$
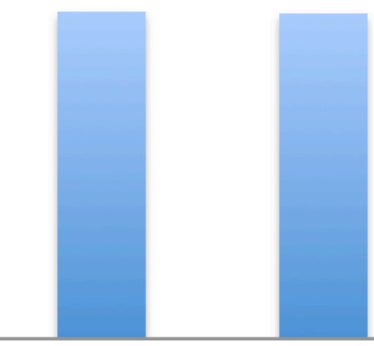

$10.7 \%$

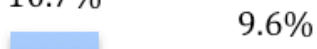

Printed

Miscellaneous

Paper

Napkins Iall

Fiber

g

Miscellaneous Miscellaneous

Materials

types)

Packaging

(including

bags / wraps)

Source: Streets Litter Re-Audit, Department of the Environment City of San Francisco, 2009 
Plastic materials were the second most large litter material observed in 2009 (San Francisco Streets Litter... 2009). Sub-categories included retail and non-retail plastic bags, as well as "zipper" lock sandwich bags. Unidentified miscellaneous plastic litter was the single largest sub-category of plastic litter (San Francisco Streets Litter... 2009). San Francisco’s litter report defines unidentified miscellaneous plastic litter as, "litter that is broken up or weathered such that auditors cannot identify it with certainty but can identify the litter as plastic" (San Francisco Streets Litter... 2009, 3). Auditors counted 219 items of miscellaneous plastic, which represented $4.88 \%$ of proportion of large litter items counted in 2009 (San Francisco Streets Litter... 2009). This proportion shows an increase of $15.3 \%$ compared to 2008 when miscellaneous plastic represented $4.66 \%$ of the large litter total of 3,978 items (San Francisco Streets Litter...2009, 53). However, the 219 miscellaneous plastic items counted in 2009 reflect a reduction by $46 \%$ compared to 2007 when 342 such items were counted. Miscellaneous plastic material accounted for nine-percent of the large litter total in 2007 (San Francisco Streets Litter...2009, 53). Table 3 lists totals for selected large litter items counted during each of the three litter audits.

\section{Table 3: San Francisco Large Litter Summary} Count Results: 2007-09, Selected Items

\begin{tabular}{|c|c|c|c|}
\hline Item & 2007 & 2008 & 2009 \\
\hline Miscellaneous Plastic & 342 & 185.5 & 219 \\
\hline Plastic Retail Bags & 23 & 25.5 & 23.5 \\
\hline Plastic Bags (Not Retail) & 71.5 & 136 & 68 \\
\hline Paper Retail Bags & 14 & 14 & 21 \\
\hline Paper Bags (Not Retail) & 42.5 & 43 & 20.5 \\
\hline Paper Bags (Fast Food) & 7 & 6 & 41 \\
\hline
\end{tabular}

As for plastic bags, they represented a much smaller proportion at $2.39 \%$ of the entire large litter count in 2009 (San Francisco Streets Litter...2009). Plastic bags include retail and 
non-retail bags, as well as "zipper" lock sandwich bags. Auditors counted 23.5 items as retail plastic bags, ranking them the third most frequently observed item in the Bags sub-category (San Francisco Streets Litter...2009, 42). This total represents $12.4 \%$ of all bags counted behind nonretail plastic bags (35.9\%) and fast food paper bags (21.9\%) (San Francisco Streets Litter...2009, 42). The 2009 retail plastic bag count dropped by just two items compared to 2008 results, which is a 7.7\% decrease (San Francisco Streets Litter...2009). However, plastic retail bags comprise slightly more than half of a percentage point of the entire large litter total in 2009 (San Francisco Streets Litter...2009, 42). This proportion is slightly lower when compared to 2007 and 2008 data. In 2008, 25.5 retail plastic bag items were counted representing $0.64 \%$ of large litter data totaling 3,978 items. In the prior year, auditors counted 23 such items equating to $0.60 \%$ of 3,812 large litter items (San Francisco Streets Litter ...2009). Figure 6 illustrates the items counted from the bag sub-category during San Francisco's litter audit in 2009.

\section{Figure 6: Amount of Items Counted from Bag Sub-Category, 2009}

\section{San Francisco Litter Re-Audit Bag Sub-Category Item Count, 2009}

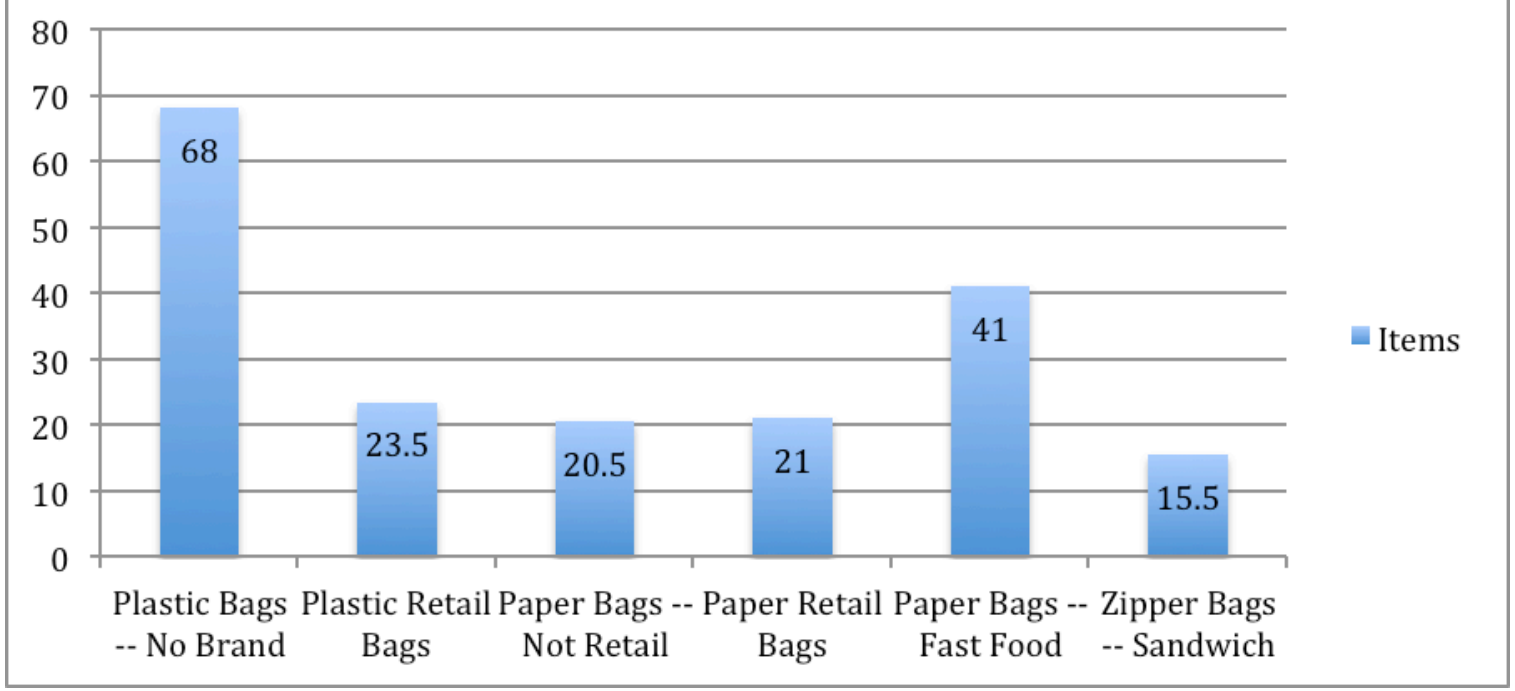

Source: City of San Francisco Department of the Environment, 2009 
Auditors counted 20.5 items identified as non-retail plastic bags in 2009. This amount accounted for fewer than $11 \%$ of the Bags sub-category data and $0.46 \%$ of the large litter total (San Francisco Streets Litter...2009, 42). Non-retail plastic bags comprised $0.31 \%$ and $0.26 \%$ of the total large litter amounts in 2007 and 2008 respectively (San Francisco Streets Litter...2009, 42). Plastic "zipper" seal bags total 15.5 items, which is $8.2 \%$ of all bags counted in 2009 and $0.35 \%$ of all large litter items counted in 2009 . Ten-and-a-half such items were counted in 2008, which reflected $0.28 \%$ of the combined large litter amount. Auditors counted 11.5 such items in 2007 and this amount represented $0.30 \%$ of all large litter items (San Francisco Streets Litter...2009, 42).

In terms of paper bags, auditors counted retail and non-retail bags, as well as fast food bags. Auditors included both whole bags and pieces of bags of all three types in their observations. Non-retail bags include bags and sacs such as "leaf bag debris" (San Francisco Streets Litter... 2009, 25). Fast food paper bags constituted their own separate large litter subcategory (San Francisco Streets Litter... 2009). Auditors counted 21paper retail bags in 2009 compared to 14 bags each in 2007 and 2008 (San Francisco Streets Litter... 2009, 37). This amount represents just over $11 \%$ of the Bags sub-category and significantly less of the proportion of large litter at less than $0.05 \%$ (San Francisco Streets Litter... 2009, 42). This proportion is higher compared to the retail paper bag data collected during the two previous audits (San Francisco Streets Litter... 2009, 42). Paper retail bags accounted for .37\% and .35\% of the bags sub-category in the 2007 and 2008 audits respectively. Figure 7 on page 40 displays the proportion each bag type comprised of the bag sub-category in 2009. 


\section{Figure 7: Percentage of Bag Sub-Category}

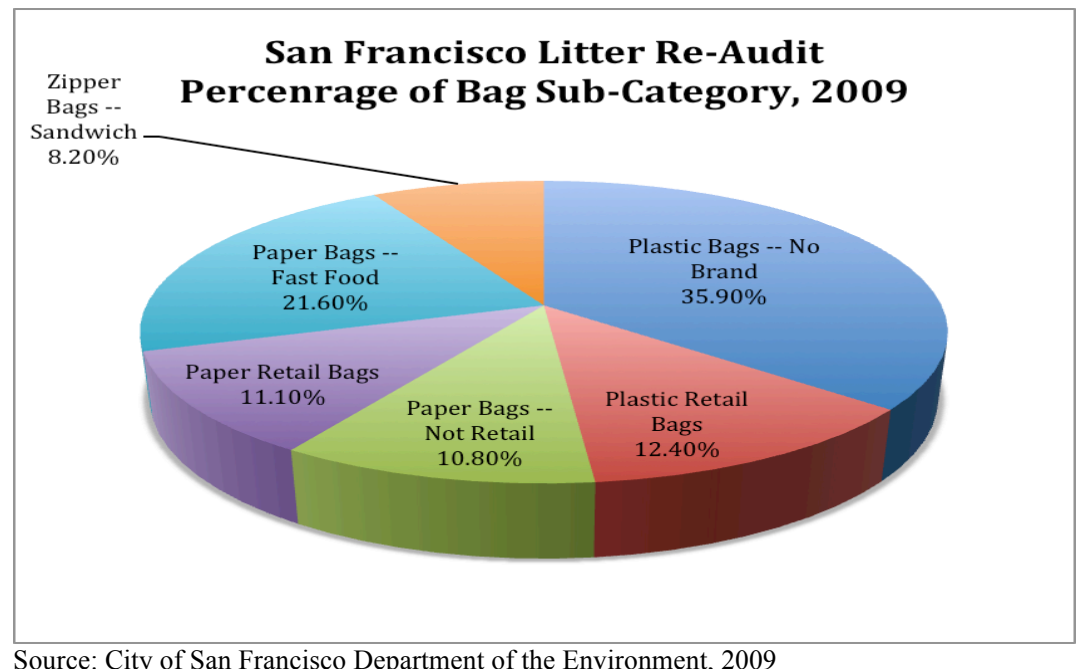

Non-retail paper bags and fast food paper bags accounted for $32.4 \%$ of the Bags subcategory in the 2009 audit. Observers counted 20.5 pieces and whole bags of non-retail paper bags and 41 fast food paper bags (San Francisco Streets Litter... 2009). Non-retail paper bags accounted for $10.8 \%$ of the 2009 Bags sub-category equaling $0.46 \%$ of all large litter data. Fast food paper bags represented $21.6 \%$ of all bags observed and less than one-percent of the 2009 large litter total. The large litter proportion of fast food paper bags in 2007 and 2008 are 1.88\% and $1.08 \%$ respectively (San Francisco Streets Litter... 2009). In sum, all pieces of paper bags and whole bags totaled 82 items. Table 4 on page 41 provides a complete breakdown by bag type, as well as comparing the percentage of total large litter between 2007 and 2008. Figure 8 (page 41) reflects the same data in a bar graph for a visual comparison. 
Table 4: San Francisco Bag Litter: Percentage of Large Litter, 2007-09, Bag Sub-Category Detail

\begin{tabular}{|c|c|c|c|c|c|}
\hline & 2009 & 2009 & 2009 & 2008 & 2007 \\
\hline Bag Type & Items* & $\begin{array}{l}\text { \% Of Sub- } \\
\text { category }\end{array}$ & $\begin{array}{l}\% \text { Of Total } \\
\text { Large Litter }\end{array}$ & $\begin{array}{l}\% \text { Of Total } \\
\text { Large Litter }\end{array}$ & $\begin{array}{l}\% \text { Of Total } \\
\text { Large Litter }\end{array}$ \\
\hline Plastic Bags -- No Brand & 68 & $35.90 \%$ & $1.52 \%$ & $3.42 \%$ & $1.11 \%$ \\
\hline Plastic Retail Bags & 23.5 & $12.40 \%$ & $0.52 \%$ & $0.64 \%$ & $0.60 \%$ \\
\hline Paper Bags -- Not Retail & 20.5 & $10.80 \%$ & $0.46 \%$ & $0.26 \%$ & $0.31 \%$ \\
\hline Paper Retail Bags & 21 & $11.10 \%$ & $0.47 \%$ & $0.35 \%$ & $0.37 \%$ \\
\hline Paper Bags -- Fast Food & 41 & $21.60 \%$ & $0.91 \%$ & $1.08 \%$ & $1.88 \%$ \\
\hline Zipper Bags -- Sandwich & 15.5 & $8.20 \%$ & $0.35 \%$ & $0.15 \%$ & $0.18 \%$ \\
\hline Totals & 189.5 & $100.00 \%$ & $4.22 \%$ & $5.91 \%$ & $4.45 \%$ \\
\hline
\end{tabular}

*Whole numbers may not appear due to averaging. Source: Streets Litter Re-Audit, City of San Francisco, 2009

\section{Figure 8: San Francisco Bag Litter: Percentage of Large Litter, 2007-09}

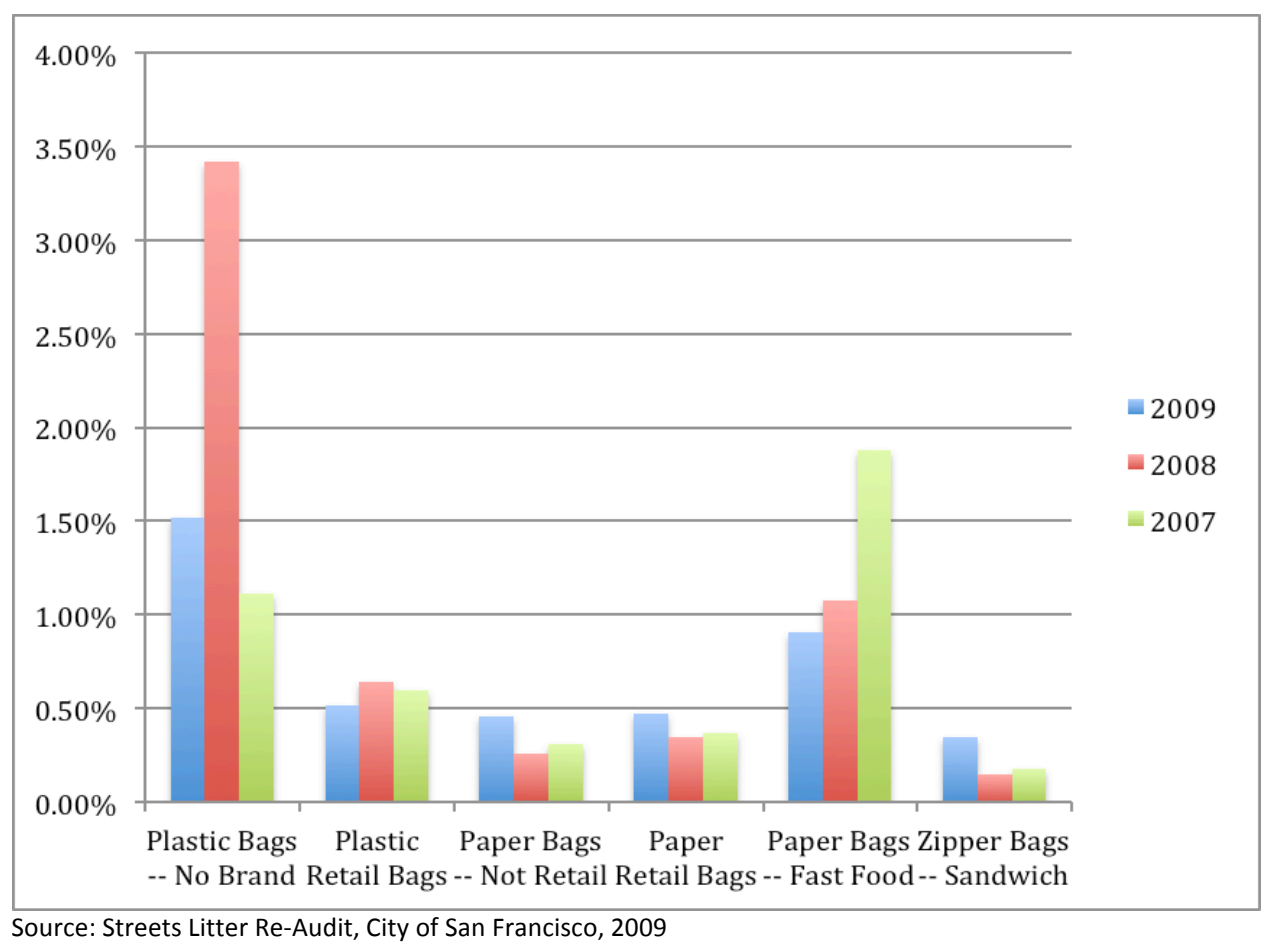

The average amount of large litter items per site varied each year between 2007 and 2009. For example, the mean amount of large litter items in the three year period between 2007 
and 2009 was highest in 2007 at 36.3 items. This higher average of items compared to 2008 (30.6 items) and 2009 (34.0 items) could be due to a smaller amount of audited sites in 2007. One-hundred five sites were audited in 2007 compared to 130 in 2008 and 132 in 2009. Despite this trend, the proportion of large litter that was bags (both branded and unbranded paper and plastic bags) in 2008 (5.91\%) was the highest proportion in the three year period. 2007's bag proportion of all litter was $4.45 \%$ and 2009 's proportion was the lowest at $4.22 \%$.

The proportion of all bag types as a percentage of large litter decreased except for both branded and unbranded plastic bags. Branded and unbranded bags accounted for $4.06 \%$ of large litter in 2008 while accounting for just $1.71 \%$ in 2007. By 2009, branded and un branded plastic bags accounted for $2.04 \%$ of all large litter. The comparable amount of audited sites in 2008 (130 sites) and 2009 (132 sites) shows a postive impact of San Francisco's bag ordinance since the propotion of plastic bags dropped by almost $50 \%$ during this time period. This conclusion is further supported by the proportion of plastic retail bags as a percentage of large litter dropped from $3.42 \%$ in 2008 to $1.52 \%$ in 2009 .

The proportion of paper bags as a percentage of large litter decreased between 2007 and 2008 from $2.56 \%$ to $1.69 \%$ before climbing $1.84 \%$. The larger sample sizes audited in 2008 and 2009 indicate an increased presence of paper bags as a whole in the litter stream based on the increase in trash items collected. As a result, the presence of retail paper bags increased by $25.54 \%$ between 2008 and 2009 indicating that consumers used more paper bags to carry their retail purchases. Fast food paper bags remained the largest proportion in the bag sub category behind plastic bags in $2008(1.08 \%)$ and $2009(0.91 \%)$. Fast food paper bags represented the larges propotion of the bag sub-category at $1.88 \%$ in 2007 while retail plastic bags accounted for $1.11 \%$. 
As for bag usage trends among consumers, SFDE representatives said that no hard data has been collected while only anecdotal observations by city employees at retailers have been conducted. These observations have not been catalogued (Phone Interview 2014).

\section{Palo Alto}

The City of Palo Alto operates the Regional Water Quality Control Plant (RWQCP), which treats wastewater before being discharged into San Francisco Bay. RWQCP treats wastewater for seven jurisdictions including Palo Alto, Mountain View, Los Altos and Stanford University. While wastewater is treated, storm drain water enters San Francisco Bay untreated. The Clean Water Act's (CWA) National Pollutant Discharge Elimination System (NPDES) permits issued by the San Francisco Regional Water Quality Control Board regulate both wastewater and storm water discharges into the San Francisco Bay. Specifically, the San Francisco Regional Water Quality Control Board issues Municipal Regional Permits (MRP) for local storm drain systems in Santa Clara County. Provision C.10 of the MRP required municipalities to reduce trash flow to storm drains by $40 \%$ by July 1, 2014. A seventy-percent reduction is required by 2017 while complete reduction is required by 2020 (Palo Alto 2014a). As a result, the Palo Alto City Council approved a "Long-Term Trash Management Plan" on January 1, 2014, and submitted it to the Regional Water Quality Control Board by February 1, 2014, as required by the MRP (Palo Alto 2014, 58). This plan includes all of the City's planned and ongoing trash management goals, as well as MRP compliance. The City of Palo Alto's Environmental Compliance Division published the Clean Bay Plan in April 2014, which details how the City will comply with MRP requirements. The Clean Bay Plan explains Palo Alto's “pollutant priorities, sources of those pollutants, pollution prevention progress made in 2013, and the tentative plan for the coming year" (Palo Alto 2014a, 2). Besides trash 
reduction, Palo Alto's pollution prevention priorities address metals like mercury and copper, as well as pesticides and salinity.

For the purposes of this outcome evaluation, findings related to single-use plastic bags as regulated by Palo Alto's Disposable Checkout Bag Ordinance are based on data presented in the Clean Bay Pollution Prevention Plan 2014 report. According to Palo Alto's 2014 Clean Bay report, plastic materials account for almost $60 \%$ of trash sited in local waterways (Palo Alto 2014a). In 2012, city staff "found approximately 340 single-use plastic checkout bags in and around local creeks and streets during two creek cleanup events and an informal 'bag sighting' survey performed by staff volunteers over a one month period" (Palo Alto 2014, 58). These activities occurred in 2012, three years following the implementation of Phase I of the City's bag ordinance, and one year prior to the implementation of Phase II.

Following the ordinance's adoption in 2009, all seven grocery stores of 10,000 square feet or greater located in Palo Alto had complied with the ordinance's requirements (Palo Alto 2014a). In 2013, the ordinance expanded to prevent all food and retail establishments from distributing plastic bags, but offer paper bags at no charge (Palo Alto 2014a). The impetus for expansion resulted from three trends. First, plastic materials continued to accumulate in city creeks and storm drains. Secondly, exit surveys at grocery stores revealed use of reusable bags among consumers "leveled out at $24 \%$," while the proportion of customers "requesting 'no bag' had plateaued at 20\% despite extensive and innovative outreach" (Palo Alto 2014a, 59).

In response to continued litter buildup in local waterways, Palo Alto city employees and volunteers from the Creek Connections Action Group collaborated during two creek litter cleanup events at the Palo Alto Baylands Nature Preserve in 2013: the National River Cleanup Day and the California National Coastal Cleanup Day. The National River Cleanup Day on May 
$18^{\text {th }}$ targeted two creeks at the Baylands: Matadero Creek and Adobe Creek. This cleanup event netted over $400 \mathrm{lbs}$. of trash and $215 \mathrm{lbs}$. of recyclable material including 12 plastic shopping bags. The most common trash items found were cigarette butts (110 items) and Styrofoam ${ }^{\mathrm{TM}}$ (61 pieces) (Palo Alto 2014a). The California National Coastal Cleanup Day on September $21^{\text {st }}$ also took place at the same two Baylands creeks resulting in over $200 \mathrm{lbs}$. of trash and $142 \mathrm{lbs}$. of recyclable items being collected. City staff and volunteers collected over 60 cigarette butts, 197 plastic food wrappers and 26 plastic shopping bags (Palo Alto 2014a). In sum, " 85 volunteers and city staff [collected] 698 pounds of trash and 357 pounds of recyclables" (Palo Alto 2014a, 64). During litter cleanup events at Matadero Creek in 2012, "staff counted 85 plastic bags [in May] and 16 plastic bags [in September]" (J.Weiss, personal communication, May 2, 2014). Table 5 below displays all results from three litter cleanup events in 2013.

\section{Table 5: 2013 Palo Alto Creek Cleanup Events Matadero Creek and Adobe Creek}

\begin{tabular}{||l|l|l|l|l|l|l|l|l||}
\hline Event & Date & $\begin{array}{l}\text { Trash } \\
\text { (Pounds) }\end{array}$ & $\begin{array}{l}\text { Recyclables } \\
\text { (Pounds) }\end{array}$ & $\begin{array}{l}\text { Cigarette } \\
\text { Butts }\end{array}$ & $\begin{array}{l}\text { Styrofoam } \\
\text { rm }\end{array}$ & $\begin{array}{l}\text { Water } \\
\text { Bottles }\end{array}$ & $\begin{array}{l}\text { Plastic } \\
\text { Shopping } \\
\text { Bags }\end{array}$ & $\begin{array}{l}\text { Other } \\
\text { Items }\end{array}$ \\
\hline $\begin{array}{l}\text { National } \\
\text { River } \\
\text { Cleanup } \\
\text { Day }\end{array}$ & May 18 & $400+$ lbs. & $215 \mathrm{lbs}$. & 110 & $\begin{array}{l}61 \\
\text { pieces }\end{array}$ & 19 & 12 bags & $\begin{array}{l}71 \text { pieces } \\
\text { of lumber } \\
\text { / building } \\
\text { pieces }\end{array}$ \\
\hline $\begin{array}{l}\text { Great } \\
\text { American } \\
\text { Pickup* }\end{array}$ & May 31 & $\mathrm{n} / \mathrm{a}$ & $\mathrm{n} / \mathrm{a}$ & 402 & $\begin{array}{l}63 \\
\text { pieces }\end{array}$ & 3 & 2 bags & $\begin{array}{l}82 \text { candy } \\
\text { wrappers }\end{array}$ \\
\hline $\begin{array}{l}\text { National } \\
\text { Coastal } \\
\text { Cleanup } \\
\text { Day }\end{array}$ & $\begin{array}{l}\text { Sept. } \\
21\end{array}$ & $200+\mathrm{lbs}$. & $142 \mathrm{lbs}$. & 60 & $\mathrm{n} / \mathrm{a}$ & $\mathrm{n} / \mathrm{a}$ & 26 bags & $\begin{array}{l}197 \\
\text { plastic } \\
\text { food } \\
\text { wrappers }\end{array}$ \\
\hline
\end{tabular}

Source: City of Palo Alto, 2014a 
Since 2009, the City of Palo Alto has implemented the use of trash booms to collect trash items afloat in local creeks. Booms are usually installed across the creeks during "the dry season to eliminate any risk of contributing to storm flow blockage in the rainy season" (Palo Alto 2014a, 64). The "dry season" is considered to last between April and November or until first flush (Palo Alto 2014a, 64). Litter was removed from the booms during the creek cleanup events in May and September. The first boom was installed on Matadero Creek downstream from a storm water pump station near Highway 101 (Palo Alto 2014a). Palo Alto's Watershed Protection Group and the Santa Clara Valley Water District agreed to install another boom across Adobe Creek last year. Following completion of the Water District's permitting process with various agencies, both trash booms were installed by early August (Palo Alto 2014a).

Litter was collected at two separate times; the first collection occurred at Adobe Creek after a rainy period in September 2013 while the other collection occurred at both creeks in December 2013 (Palo Alto 2014a). This first collection resulted in "41 balls (mostly tennis balls), four plastic shopping bags, 27 miscellaneous plastic bags, 250 Styrofoam TM chunks / pieces, 19 candy wrappers, 17 Styrofoam ${ }^{\mathrm{TM}}$ serviceware items and 37 plastic beverage and water bottles" (Palo Alto 2014a, 64). During the second collection in December, trash items included "114 balls (mostly tennis balls), zero plastic shopping bags, six miscellaneous plastic bags, 277 Styrofoam ${ }^{\mathrm{TM}}$ pieces / chunks, 15 candy wrappers, 11 Styrofoam ${ }^{\mathrm{TM}}$ serviceware items, 48 plastic beverage and water bottles and 19 empty spray paint cans" (Palo Alto 2014, 64). Table 6 on page 47 shows the results from the Adobe Creek cleanup event in September 2013. 
Table 6: Adobe Creek Trash Boom Collection Results - September 2013

\begin{tabular}{||l|l|l|l|l|l|l||}
\hline \hline $\begin{array}{l}\text { Styrofoam } \\
\text { Pieces }\end{array}$ & Balls* & $\begin{array}{l}\text { Beverage } \\
\text { Bottles }\end{array}$ & $\begin{array}{l}\text { Candy } \\
\text { Wrappers }\end{array}$ & $\begin{array}{l}\text { Styrofoam } \\
\text { Serviceware }\end{array}$ & $\begin{array}{l}\text { Miscellaneous } \\
\text { Plastic }\end{array}$ & $\begin{array}{l}\text { Plastic } \\
\text { Shopping } \\
\text { Bags }\end{array}$ \\
\hline 250 & 41 & 37 & 19 & 17 & 27 & 4 \\
\hline \hline
\end{tabular}

*Mostly tennis balls, Source: City of Palo Alto, 2014a

Since municipalities had to demonstrate a $40 \%$ trash load reduction by

July 1, 2014 to meet the Water Boards' municipal regional permit requirements, Palo Alto's

Engineering Services Department installed two trash capture devices in 2012. These two devices known as hydrodynamic vortex separators were "installed in a section of the City's

[municipal separate storm sewer systems] MS4 along Park Boulevard” (Palo Alto 2014a, 65).

These devices "intercept and capture trash from a 180-acre tributary drainage area [including] a section of the El Camino Real commercial corridor" (Palo Alto 2014a, 65). On June 11, 2013, $90 \%$ of the material found in the hydrodynamic vortex separators was leaves and organic debris.

The sorted trash from this material included "Styrofoam"TM peanuts, balls, plastic bottles and aluminum cans" (Palo Alto 2014a, 65). No data of litter in storm drain catch basins exist because litter is not counted in these locations (Weiss E-mail 2014).

From an anecdotal perspective, Palo Alto staff members have noticed "much fewer bags on local streets" (Weiss E-mail 2014). Prior to the ordinance's expansion in 2013, city staff counted 120 bags on city streets during a one-month informal survey (Weiss E-mail 2014). However, "only eight bags were counted during the same time frame" (Weiss E-mail 2014). Anecdotal feedback in the form observations from personnel at recycling and garbage processing facilities indicate a slight decrease of plastic material. Green Waste of Palo Alto representatives say, "We have seen a reduction of film in our loads delivered. However, it is not a major change 
since it reduced our count by one bale” (Weiss E-mail 2014). Trash load processing at Green Waste results in " 11 bales per day weighing an average of 1,800 pounds each" (Weiss personal communication, May 2, 2014).

Even though all seven grocery stores of at least 10,000 square feet complied with Palo Alto's Checkout Bag Ordinance, city staff still noticed plastic litter accumulating in local creeks and storm drains (Palo Alto 2014a). In addition, store exit surveys revealed reusable bag use among consumers tapered off at $24 \%$ while customers carrying items without bags plateaued at 20\% (Palo Alto 2014a). These trends led city decision makers to expand the Checkout Bag ordinance in July 2013 to include all retail service and food service establishments to reduce the presence of single-use plastic bags in creeks and storm drains. Plastic bags without handles intended to contain produce, bulk items and free liquids like soups were permitted by the ordinance (Palo Alto 2013a).

As a result, the more than $200 \mathrm{lbs}$. of litter collected at Matadero and Adobe Creeks in September 2013 represented nearly a 50\% drop compared to the amount collected four months earlier in May (> 400 lbs.) (Palo Alto 2014a). The amount of recyclable materials dropped by $33.9 \%$ from 215 pounds in May to 142 pounds in September. However, the number of retail plastic bags increased from 12 bags in May to 26 bags in September (Palo Alto 2014a). By December 2013, only four retail plastic bags were collected in the trash booms at Adobe and Matadero Creeks during three separate collections (Palo Alto 2014a). This data indicates the expanded ordinance's environmental impact by prohibiting all local retail and food service businesses from distributing single-use plastic bags. 


\section{Retail Bag Trends Pre and Post Ordinance Expansion}

Between January and March 2014, city employees surveyed 33 large retailers with store sizes greater than 10,000 square feet via telephone calls to gauge compliance following expansion of the Disposable Checkout Bag Ordinance (Palo Alto 2014b). The expanded ordinance, which became effective on July 1, 2013, prevents all retail and food service businesses from issuing single-use plastic bags (Palo Alto 2013a). It also requires a ten-cent fee for paper and recyclable bags at retailers only (Palo Alto 2013a). Store managers from 27 stores responded to telephone surveys regarding bag types, bag fees, sales and record keeping, as well as bag material content and labeling. Four of the stores did not respond to the phone surveys and subsequently underwent on-site surveys by city staff. Of the 33 large retailers surveyed, 31 such businesses offered bags to customers while two did not offer bags of any kind (Palo Alto 2014b). These 31 retail businesses, which include all grocery stores and pharmacies, do not distribute single-use plastic bags as codified by the Checkout Bag Ordinance (Palo Alto 2014b). In addition, all 31 retail establishments charge the ten-cent minimum fee for each paper or reusable bag that is purchased (Palo Alto 2014b).

Additional survey information from the 27 stores that responded via telephone revealed that, " 23 of 27 retailers ( $85 \%$ ) offer only paper bags for the ten-cent charge. Of these, at least two retailers may be providing thin, single-use paper bags rather than durable paper bags, based on [store representatives'] descriptions of the material" (Palo Alto 2014b. n.p.). In addition, "two of the 27 retailers (7.4\%) only provide reusable bags" while two other retailers, offer "both reusable plastic bags and paper bags" (Palo Alto 2014b n.p.). Lastly, "seven of the 27 retailers (26\%)... provide a durable reusable bag that is neither paper [nor] plastic [and] exceed[s] ordinance 
requirements" (Palo Alto 2014b, n.p.) These bags cost between $\$ 1.00$ and $\$ 2.00$ (Palo Alto 2014b).

With regard to bag sales data and record keeping, just 12 of the 27 stores that responded to the phone survey were able to provide actual sales records despite repeated requests for such information (Palo Alto 2014b). City staff sought bag sales data within the first six months of the ordinance's expansion between July and December 2013. Over one million bags were sold from these 12 retail establishments during this time period (Palo Alto 2014b). Bag sales data were not collected for all 31 retailers prior to the ordinance's expansion in 2013, and as a result, "a comparison in the reduction of bag sales" before and after expansion is not available (Palo Alto 2014b, n.p.). From an anecdotal perspective, retail personnel observed a noticeable decrease in the amount of bags distributed to consumers. For example, store representatives for two large retailers from the Stanford Mall, "noted that for the bag-ordering period that included the holiday season, their bag demand fell 30 to 50 percent" compared to the same time period during the previous year (Palo Alto 2014b, n.p.). Management representatives from some retailers observed similar reductions while other retail businesses noticed no change (Palo Alto 2014b, n.p.).

\section{Store Exit Surveys: Grocery Stores}

In addition to collecting litter and bag sales data, City employees conducted store exit surveys at grocery stores and pharmacies every year between 2008 and 2014 to gauge which bag types consumers used. Employees tallied observations into four categories: reusable bags, paper bags, plastic bags and no bag. The amount of bags observed at grocery stores during the sevenyear period dropped 52.8\% from the high mark of 3,802 bags in 2008 to the low mark of 1,795 bags in 2014 (Palo Alto 2014d). The overall bag totals are the difference between the total number of observations and total instances of customers without bags to accurately see the 
change in bag use. Based on the provided data from the City of Palo Alto, the researcher interpreted these results performing calculations to identify data trends. For example, city employees noticed the number of consumers seen using reusable bags to carry grocery items increased by $65.5 \%$ between 2008 and 2014 (2014d). Employees counted 371 reusable bags in 2008, which was the lowest total for this subcategory and accounted for nine-percent for the overall grocery bag count in 2008 (Palo Alto 2014d). Between 2009 and 2013, the amount of reusable bags observed averaged 754.8 bags per year (Palo Alto 2014d). The highest total during this five-year period was 807 bags in 2011 while the lowest total during this period was 663 bags in 2012 (Palo Alto 2014d). The largest proportion of the overall bag total that were reusable bags during this five-year period was $24.4 \%$ in 2013 while $19.0 \%$ was the lowest proportion in 2009 (Palo Alto 2014d).

The reusable bag count increased to a high mark of 1,076 reusable bags in 2014, which represented 39.5\% of this subcategory (Palo Alto 2014d). The amount of reusable bags averaged $21.4 \%$ of the overall bag count from 2009 through 2013 . The greatest proportional year-to-year increase occurred from 2008 to 2009 (Palo Alto 2014d). During this period, the amount of reusable bags observed increased from 371 bags in 2008 to 700 bags a year later, which equated to a $47 \%$ increase (Palo Alto 2014d). In addition, the proportion of reusable bags' to the overall grocery store bag count increased by 10\% from nine-percent to 19\% (Palo Alto 2014d). The reusable bag count at grocery stores decreased only once between 2011 and 2012 (Palo Alto 2014d). The reusable bag count decreased by $17.8 \%$ from 807 bags to 663 bags during this time period (Palo Alto 2014d).

The proportion of recyclable paper bags observed to the overall bag count averaged $57.9 \%$ between 2010 and 2013 before dropping to $26.4 \%$ in 2014 (Palo Alto 2014d). However, 
the number of recyclable paper bags observed by city staff members decreased by $46.9 \%$ from 2008's total of 1,354 bags to 2014's total of 719 bags (Palo Alto 2014d). The 719 bags, which was the lowest amount observed in a single year during the seven-year period, represented $26.4 \%$ of all observations in 2014 (Palo Alto 2014d). The largest amount of recyclable paper bags counted was 2,270 in 2010 , which accounted for $59.4 \%$ of the overall grocery store bags count that year (Palo Alto 2014d). The single largest increase in recyclable paper bags occurred between 2009 and 2010. The number of such observations jumped by $38.9 \%$ during this time period. However, in 2011, the frequency of recyclable paper bag observations began to decrease. The number of recyclable paper bags decreased from 2,270 bags to 719 bags between 2010 and 2014 equaling a 67.4\% drop (Palo Alto 2014d). The single largest decline in recyclable paper bag observations occurred between 2013 and 2014. During this time period, the amount of recyclable bags observed dropped by $60.5 \%$ from 1,820 bags to 719 bags (Palo Alto 2014d).

Observations of single-use plastic bags totaled 2,077 bags in 2008 and 1,000 bags in 2009 (Palo Alto 2014d). The 2,077 bags accounted for 50.5\% of the total bag count in 2008 while the 1,000 bags accounted for $27.2 \%$ of the total bag count in 2009 (Palo Alto 2014d). Following the implementation of Palo Alto's Disposable Checkout Bag Ordinance in September 2009, city employees observed zero bags at grocery locations from 2010 to 2014 (Palo Alto 2014d). Observations of single-use plastic bags declined at a rate 51.9\% from 2008 to 2009 .

The total observations of consumers using no bags averaged $19.4 \%$ of the overall observations from 2009 through 2013. In 2008, 313 "no bag" observations accounted for 7.6\% of all observations. The 313 observations of no bags used are the lowest single total of the entire grocery data set (Palo Alto 2014d). By 2014, "no bag" observations increased to 931 tallies, which translated to $34.2 \%$ of all observations in 2014 (Palo Alto 2014d). The 931 observations 
of no bags being used in 2014 is the highest such count in the "no bag" subcategory (Palo Alto 2014d). The number of "no bag" observations increased by $66.4 \%$ from 2008 's total of 313 to 2014's 931 (Palo Alto 2014d). The largest year-to-year increase occurred between 2008 and 2009 at $46.5 \%$. The observations of no bags increased from 313 tallies to 596 tallies during this time period (Palo Alto 2014d). The amount of "no bag" observations increased from 656 tallies in 2013 to 931 tallies in 2014, which equates to 29.5\% jump (Palo Alto 2014d). The data in Table 7 below reflects that observations of no bags used decreased once by a marginal proportion of 3.3\% between 2012 (679 observations) and 2013 (656 observations) (Palo Alto 2014d). Figure 9 on page 54 presents this data in a line graph.

\section{\begin{tabular}{|c||}
\hline \hline Table 7: Palo Alto Disposable Checkout Bag Ordinance \\
Store Exit Surveys of Customer Bag Types: Grocery (2008-2014) \\
\hline
\end{tabular}}

\begin{tabular}{||c|c|c|c|c|c|c|c|c|c||}
\hline \hline $\begin{array}{c}\text { Type of Store } \\
\text { Observations }\end{array}$ & Reusable & $\begin{array}{c}\% \text { of } \\
\text { Total }\end{array}$ & Paper & $\begin{array}{c}\% \text { of } \\
\text { Total }\end{array}$ & Plastic & $\begin{array}{c}\% \text { of } \\
\text { Total }\end{array}$ & $\begin{array}{c}\text { No } \\
\text { Bag }\end{array}$ & $\begin{array}{c}\% \text { of } \\
\text { Total }\end{array}$ \\
\hline $\begin{array}{c}2008 \\
\text { Grocery }\end{array}$ & 4,115 & 371 & $9.0 \%$ & 1,354 & $32.9 \%$ & 2077 & $50.5 \%$ & 313 & $7.6 \%$ \\
\hline $\begin{array}{c}2009 \\
\text { Grocery }\end{array}$ & 3,683 & 700 & $19.0 \%$ & 1,387 & $37.7 \%$ & 1000 & $27.2 \%$ & 596 & $16.2 \%$ \\
\hline $\begin{array}{c}2010 \\
\text { Grocery }\end{array}$ & 3,820 & 803 & $21.0 \%$ & 2,270 & $59.4 \%$ & 0 & $0.0 \%$ & 747 & $19.6 \%$ \\
\hline $\begin{array}{c}2011 \\
\text { Grocery }\end{array}$ & 3,711 & 807 & $21.7 \%$ & 2,167 & $58.4 \%$ & 0 & $0.0 \%$ & 737 & $19.9 \%$ \\
\hline $\begin{array}{c}2012 \\
\text { Grocery }\end{array}$ & 3,208 & 663 & $20.7 \%$ & 1,866 & $58.2 \%$ & 0 & $0.0 \%$ & 679 & $21.2 \%$ \\
\hline $\begin{array}{l}2013 \\
\text { Grocery }\end{array}$ & 3,277 & 801 & $24.4 \%$ & 1,820 & $55.5 \%$ & 0 & $0.0 \%$ & 656 & $20.0 \%$ \\
\hline $\begin{array}{l}2014 \\
\text { Grocery }\end{array}$ & 2,726 & 1,076 & $39.5 \%$ & 719 & $26.4 \%$ & 0 & $0.0 \%$ & 931 & $34.2 \%$ \\
\hline
\end{tabular}

Source: City of Palo Alto, 2014d

Overall, the observations of single-use plastic bags and recyclable paper bags used by consumers decreased during the seven year survey period while the observations of consumers with reusable bags and without bags increased. Specifially, reusable bag use and no bag use by 
consumers jumped 47.0\% each in 2009 when the Checkout Bag ordinance became law.

Consumers reacted by either paying the fee a limited time for a small amount of reusable bags or elceting no bag for items. Meanwhile, observations of paper bags decreased by $68.3 \%$ between 2010 and 2014 while the frequency of reusable bags incraesed every year except 2012. Instances of no bags used flucuated between 2010 and 2013 before increasing $29.5 \%$ to 931 tallies in 2014 .

\section{Figure 9: Grocery Exit Survey Results of Customer Bag Types, 2008-2014}

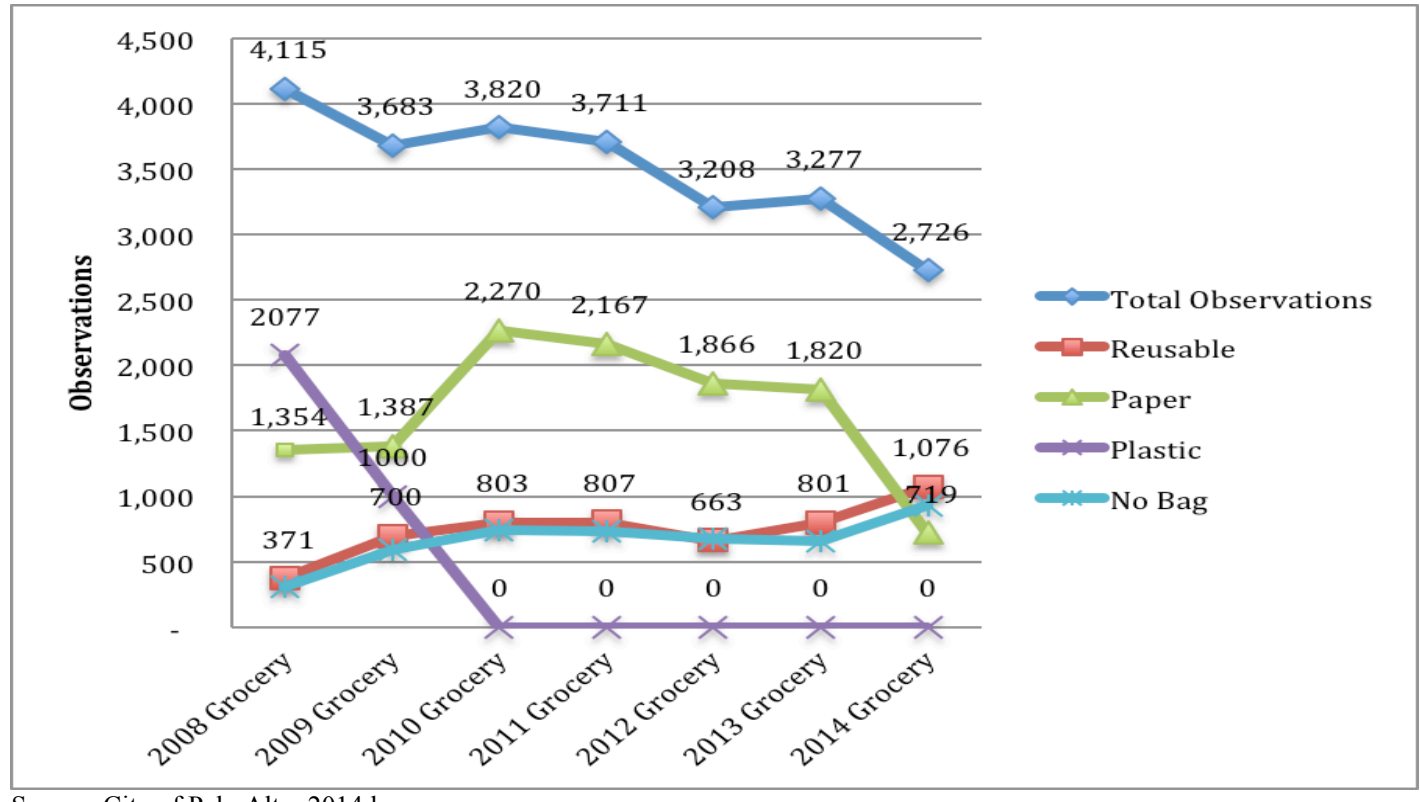

Source: City of Palo Alto, 2014d

These trends show Palo Alto's Checkout Bag ordinance achieved its legislative intent by changing consumer norms about bag use.

Continuing with the overall trend appraoch, the amount of bags observed dropped from 3,802 bags in 2008 to 1,795 bags in 2014 highlighted by the nearly $47 \%$ drop in paper bags and the elimination of retail plastic bags. Observations of reusable bags jumped by $65.5 \%$ as consumers opted for more durable recepacles than paper bags since fees were attached to both available bag options. Moreover, consumers felt no need to pay bag fees for items they could carry by hand resulting in a $66.4 \%$ jump in this category. These trends can be tied to the reduced 
presence of single-use plastic bags and litter in general that accumulated in creeks and storm drains.

\section{Store Exit Surveys: Pharmacies}

The overall bag count tallied at pharmacies fluctuated between 2008 and 2014. For example, the total number of bags increased each year between 2008 and 2010 from 202 bags to 387 before decreasing to 317 bags in 2011 . These numbers are the differences between the total number of observations and the no bag counts for their respective years. Total observations of pharmacy customers with bags move back to 387 tallies in 2012 before dropping slightly to 337 tallies in 2013. Following ordinance expansion in 2013, only 180 bags total were counted in 2014. The 387 bags observed in 2010 and 2012, represented the highest total in the entire pharmacy bag data table.

Reusable bags on average accounted 5.02\% (27.67 bags) of the overall pharmacy bag count from 2008 to 2013 . However, reusable bags accounted for $15.8 \%$ of all bags observed with 98 tallies in 2014. The 98 tallies are the highest single-year total in the pharmacy bag data set. The amount of pharmacy patrons with reusable bags increased by 62 tallies between 2013 and 2014, which was largest increase in terms of tallies. This change represented the second largest proportional increase from one year to another at $63.3 \%$. The largest proportional increased occurred between 2008 and 2009. During this time period, the total amount of observations of customers with reusable bags grew from six bags to 22 bags, which translated to a $73.0 \%$ jump. The largest decrease in reusable bags observed occurred when the total amount dropped from 38 bags to 27 bags between 2010 and 2011. This change represented a proportional drop of 18.9\%.

Despite some slight fluctuations in this data set, the amount of reusable bags observed in 2008 
(six bags) compared to the amount of bags observed in 2014 (98 bags) represented a 99.94\% jump.

Observations of pharmacy patrons using recyclable paper bags reflect a "peaks and valleys" pattern characterized by high totals and low totals. For example, city staff observed zero paper bags in 2008 and 2009 before counting 127 paper bags in 2010. This volatile pattern continued with 92 paper bags observed in 2011 before increasing to 139 paper bags observed in 2011. The last two years of the exit surveys illustrate a downward trend with 120 paper bags observed in 2013 and 82 paper bags observed a year later. The 82 bags observed is the lowest single year total aside from the zero observations in 2008-09. The 82 bags observed in 2013 accounted for $13.2 \%$ of the pharmacy bag observations that year. This proportion is the lowest single-year proportion other than zero percent (2008 and 2009).

On the other hand, 2012's 139 tallies of paper bags accounted for the highest single-year total in this data set, which equated to $21 \%$ of the overall pharmacy count. The $21 \%$ portion was the largest proportion of the entire paper bag subcategory. This amount of observations reflected a 33.8\% increase from 2011's total paper bag observations of 92 , which accounted for $18.5 \%$ of all pharmacy observations that year. The largest increase of the paper bag subcategory occurred between 2009 and 2010 when the amount of observations increased from zero to 127 . The proportion of paper bags observed in all years excluding 2008 and 2009 (zero percent) averaged $18.2 \%$. Table 8 on page 57 breaks down the frequency of each bag type observed compared to the overall observations of each year. Figure 10 on page 58 illustrates the data in a line graph. 
Table 8: Palo Alto Disposable Checkout Bag Ordinance Store Exit Surveys of Customer Bag Types: Pharmacy (2008-2014)

\begin{tabular}{||l|l|l|l|l|l||}
\hline \hline Type of Store & Total Observations & Reusable & Paper & Plastic & No Bag \\
\hline 2008 Pharmacy & 270 & 6 & 0 & 196 & 68 \\
\hline 2009 Pharmacy & 405 & 22 & 0 & 269 & 114 \\
\hline 2010 Pharmacy & 659 & 38 & 127 & 222 & 272 \\
\hline 2011 Pharmacy & 498 & 27 & 92 & 198 & 181 \\
\hline 2012 Pharmacy & 662 & 37 & 139 & 211 & 275 \\
\hline 2013 Pharmacy & 630 & 36 & 120 & 181 & 293 \\
\hline 2014 Pharmacy & 620 & 98 & 82 & 0 & 440 \\
\hline \hline
\end{tabular}

Source: City of Palo Alto, 2014d

Analyzing trends indicates that no bag observations reflected a mostly upward trend as illustrated by three straight years of increases from 2012 to 2014, which are the three highest single totals of any category during the seven-year survey period. The fourth highest observation total was 272 tallies of no bags used in 2010. This data shows that customers most likely purchased one to five items that could be carried in-hand or in pockets, backpacks, and purses to name a few examples other than bags. Also, people usually buy small items such as prescription medicines and toiletries at pharmacies, which can be carried in-hand. In this case, customers elected against paying for either reusable or paper bags. People's choice of using no bags results in less litter in Palo Alto's garbage stream.

As for the other categories, plastic bags experienced a gradual decline before sinking from 181 tallies in 2013 to zero a year later as the expanded ordinance eliminated single-use plastic bags from all retailers and food service providers. The City's educational efforts also informed residents of plastic bags' environmental dangers helping people make informed choices when shopping and eating. Paper bags saw slight changes between 2010 and 2013 before planning in 2014 while reusable bags experienced a moderate gain in 2014. However, all bag 
options could not equal the "no bag" tallies from 2010 onward, especially after ordinance expansion in 2013.

\section{Figure 10: Pharmacy Exit Survey Results of Customer Bag Types, 2008-2014}

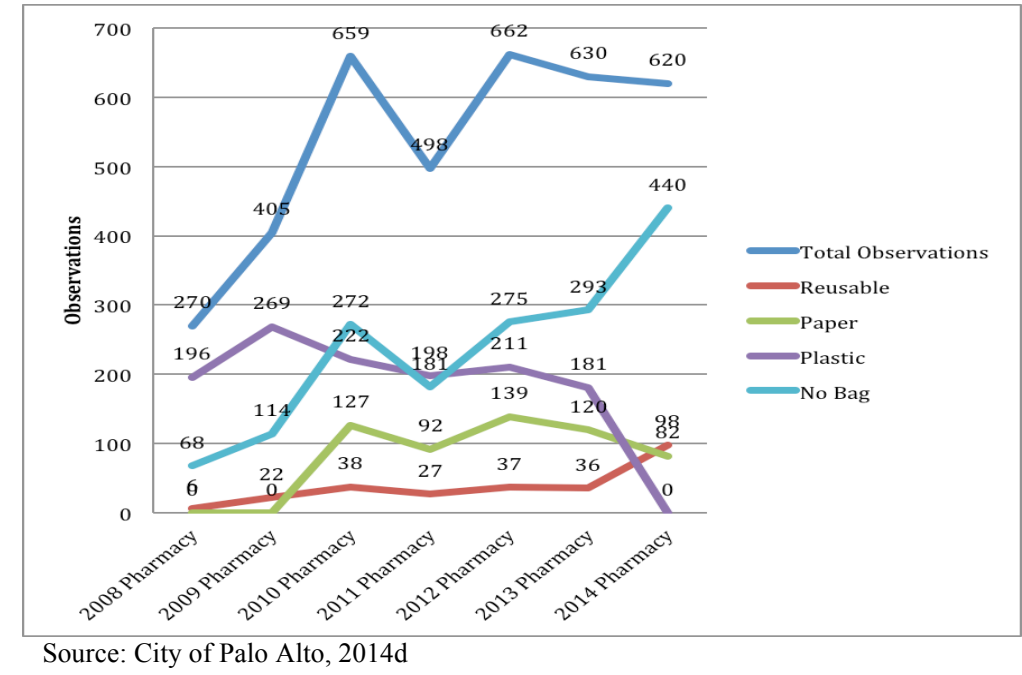

\section{Overall Trends in Palo Alto}

The overall bag count from both grocery and pharmacy observations combined fluctuated between 2008 and 2014. Specifically, the total combined plastic bag count totaled 2,273 bags in 2008, representing the largest proportion of all categories at 51.8\%. However, that proportion dropped to $31.0 \%$ (1,354 bags) in 2009 when Palo Alto decision makers implemented Phase One of the Checkout Bag Ordinance. The plastic bag proportion plummeted to five-percent of the overall combined observation count in 2010. Furthermore, the plastic bag count fluctuated between 4.6\% (2013) and 5.5\% (2012) before reaching zero-percent in 2014. Paper bags were the second most frequently observed bag-usage trend by Palo Alto city staff in 2008 at 1,354 bags accounting for $30.9 \%$ of the total proportion of bags that year. That same year, observations of no bag used accounted for 8.7\% (381 observations) of the combined bag count while reusable bags represented $8.6 \%$ (377 bags). 
In 2009 , city staff most frequently observed consumers using recyclable paper bags at $33.9 \%$ (1,387 bags) of the combined total. This trend continued through 2013. Plastic bags accounted for the second most observed bag usage trend at 31.0\% (1,269 bags) with reusable bags at $17.7 \%$ (722 bags) and no bag used at $17.4 \%$ (710 observations) to round out the combined totals in 2009. Following the implementation of Phase One of Palo Alto's Checkout Bag Ordinance in 2009, the proportions of all categories increased except plastic bags in 2010. Observations of paper bags jumped to $53.5 \%$ of the combined observations while no bags increased to $22.8 \%$ and reusable bags increased to $18.8 \%$. Instances of consumers using plastic bags dropped to $5 \%$.

From 2010 to 2013, observations reflected the following results in descending order in terms of proportion of the total combined count of grocery and pharmacy observations: recyclable paper bags, no bag, reusable bags and plastic bags. During this time period, the proportion of each category fluctuated slightly. Proportionately, paper bags ranged between $49.7 \%$ (1,940 bags) in 2013 to $53.7 \%$ (2,259 bags) in 2011. Observations of no bags used ranged from $21.8 \%$ (918 observations) in 2011 to $24.7 \%$ (954 observations) in 2012. Instances of reusable bags seen in exit surveys ranged between $18.1 \%$ (700 bags) in 2012 and $21.4 \%$ (837 bags) in 2013. Observations of plastic bags ranged from 4.6\% (181 bags) in 2013 to 5.5\% (211 bags) in 2012.

Following the implementation of Phase II of the Checkout Bag Ordinance in 2013, city staff observed more instances of no bags and reusable bags during exit surveys. Phase II applied to all retailers in Palo Alto. While no bags accounted for $41.0 \%$ (1,371 observations) of the combined total proportion of grocery and pharmacy exit surveys, reusable bags represented $35.1 \%$ ( 1,174 bags) of exit surveys in 2014. Moreover, paper bags comprised 23.9\% (801 bags) 
of the combined total while plastic bags dropped to $0 \%$. Table 9 on page 60 lists the overall bag data collected from grocery stores and pharmacies. Figure 11 on page 61 illustrates this data in a line graph.

Examined individually, exit survey data revealed fluctuations within each category. Proportionally, observations of reusable bags ranged from $8.6 \%$ (377 bags) in 2008 to $35.1 \%$ (1,174 bags) in 2014. Between 2009 and 2013, the proportion of reusable bags relative to the total bags counted fluctuated between $17.7 \%$ (722 bags) in 2009 and 21.4\% (837 bags) in 2013. Observations of reusable bags increased by $45.2 \%$ between 2008 and 2010 from 377 bags to 841 bags. However, such observations decreased by $16.8 \%$ between 2010 and 2012 from 841 bags to 700 bags. The proportion of reusable bags increased slightly by $16.4 \%$ between 2012 and 2013 from 700 bags to 837 bags before jumping by $41.4 \%$ from 2013 to 2014 . The number of reusable bags observed reached its highest total in 2014 with 1,174 bags.

Table 9: Palo Alto Disposable Checkout Bag Ordinance Store Exit Surveys of Customer Bag Types: Combined (2008-2014)

\begin{tabular}{||c|c|c|c|c|c|c|c|c|c||}
\hline \hline & $\begin{array}{c}\text { Total } \\
\text { Observations }\end{array}$ & Reusable & $\begin{array}{c}\% \text { of } \\
\text { Total }\end{array}$ & Paper & $\begin{array}{c}\% \text { of } \\
\text { Total }\end{array}$ & Plastic & \% of Total & $\begin{array}{c}\text { No } \\
\text { Bag }\end{array}$ & $\begin{array}{c}\% \text { of } \\
\text { Total }\end{array}$ \\
\hline $\begin{array}{c}2008 \\
\text { Total }\end{array}$ & 4,385 & 377 & $8.6 \%$ & 1354 & $30.9 \%$ & 2273 & $51.8 \%$ & 381 & $8.7 \%$ \\
\hline $\begin{array}{l}2009 \\
\text { Total }\end{array}$ & 4,088 & 722 & $17.7 \%$ & 1387 & $33.9 \%$ & 1269 & $31.0 \%$ & 710 & $17.4 \%$ \\
\hline $\begin{array}{c}2010 \\
\text { Total }\end{array}$ & 4,479 & 841 & $18.8 \%$ & 2397 & $53.5 \%$ & 222 & $5.0 \%$ & 1019 & $22.8 \%$ \\
\hline $\begin{array}{c}2011 \\
\text { Total }\end{array}$ & 4,209 & 834 & $19.8 \%$ & 2259 & $53.7 \%$ & 198 & $4.7 \%$ & 918 & $21.8 \%$ \\
\hline $\begin{array}{c}2012 \\
\text { Total }\end{array}$ & 3,870 & 700 & $18.1 \%$ & 2005 & $51.8 \%$ & 211 & $5.5 \%$ & 954 & $24.7 \%$ \\
\hline $\begin{array}{c}2013 \\
\text { Total }\end{array}$ & 3,907 & 837 & $21.4 \%$ & 1940 & $49.7 \%$ & 181 & $4.6 \%$ & 949 & $24.3 \%$ \\
\hline $\begin{array}{c}2014 \\
\text { Total }\end{array}$ & 3,346 & 1,174 & $35.1 \%$ & 801 & $23.9 \%$ & 0 & $0.0 \%$ & 1371 & $41.0 \%$ \\
\hline \hline
\end{tabular}

Source: City of Palo Alto, 2014d 
The proportion of paper bags observed ranged between $23.9 \%$ ( 801 bags) in 2014 and $53.7 \%$ (2,259 bags) in 2011. The highest number of paper bags observed by city staff was 2,397 bags in 2010 , which equated to $53.5 \%$ of the combined total that year. The 801 bags observed in 2014 represented the lowest such count in the data set in Table 9 on page 60 Between 2008 and 2011 , the proportion of paper bags increased from 30.9\% (1.354 bags) to 53.7\% (2.259 bags). The proportion of paper bags decreased from $53.7 \%$ in 2011 to $23.9 \%$ in 2014 . In other words, the number of bags decreased from 2,259 to 801, which represents a decrease of $66.6 \%$. Figure 11 below shows the downward trends in paper bags, plastic bags and overall observations compared to the upward trends in reusable bags and instances of no bag used.

Figure 11: Store Exit Surveys of Customer Bag Types, 2008-14 (Grocery \& Pharmacy Combined)

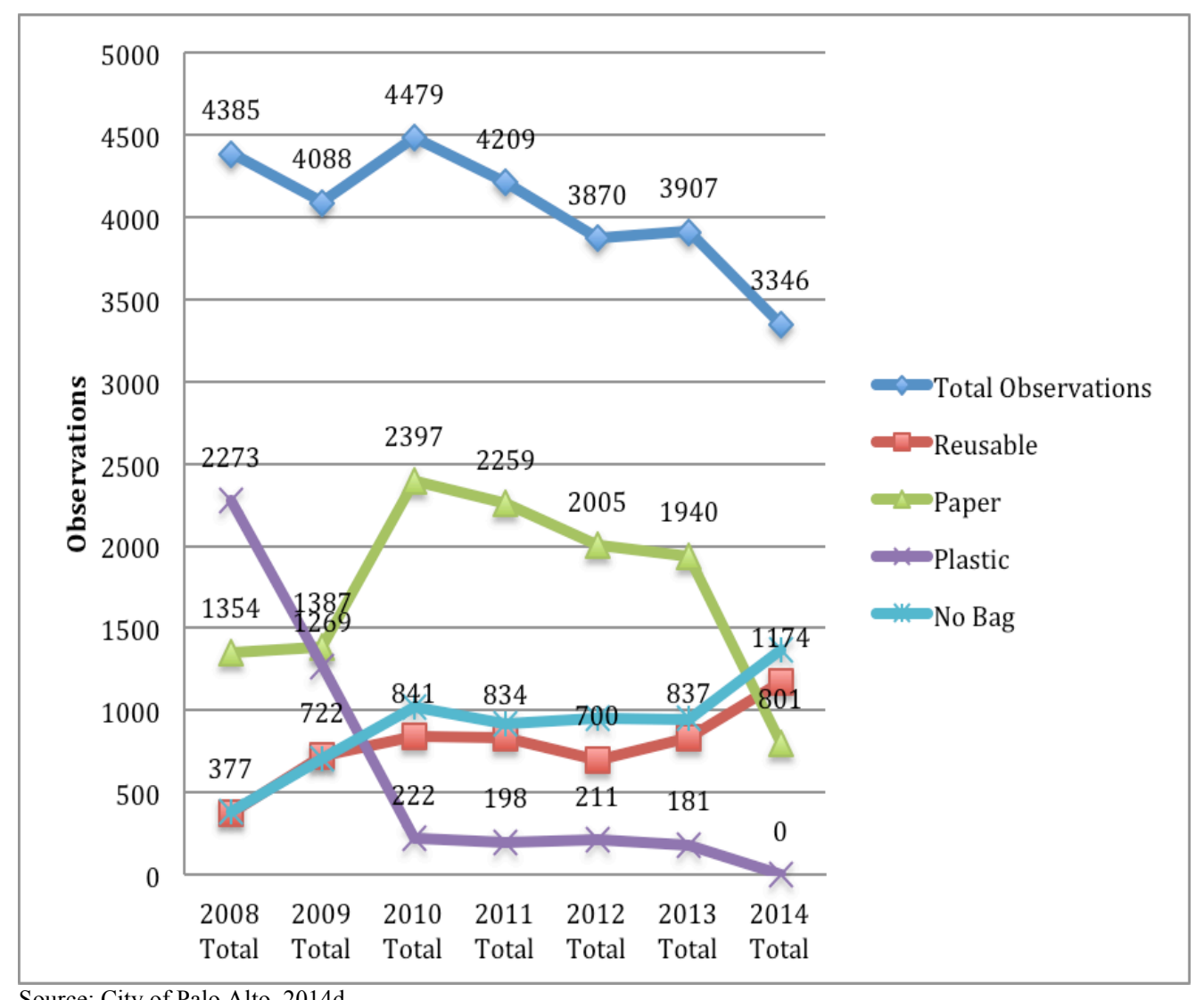

Source: City of Palo Alto, 2014d 


\section{San Jose}

\section{On-Land Litter Results}

The impetus for San Jose's Bring You Own Bag Ordinance (BYOB) was based on mitigating environmental hazards. The executive summary included in a memorandum from November 20, 2012, detailing BYOB implementation results says, "Several local waterways have been formally listed as 'impaired by trash' under the Federal Clean Water Act (1972) (San Jose 2012b, 3). Water sources in San Jose include Silver Creek, Coyote Creek, Saratoga Creek, San Tomas Aquino Creek, the Guadalupe River, and the lower San Francisco Bay shoreline" (San Jose 2012b, 3).

Therefore, city staff conducted multiple litter surveys between 2009 and 2010 to assess the extent of litter in San Jose's creeks, waterways and public spaces. City staff then compared pre-ordinance data with post ordinance data collected in 2012 and 2013, which is presented in Table 10 on page 63. In 2009, city employees surveyed 48 on-land sites in neighborhoods throughout San Jose and collected 7,917 items of trash, 387 of which were retail plastic bags. This amount of single-use plastic bags accounted for $4.9 \%$ of the total trash collected (San Jose 2013d). Table 11 on page 64 lists in detail how many of each bag type was collected during the site surveys in 2009. The accompanying pie chart in Figure 12 on page 64 provides a visual representation of this data table.

A year later, in 2010, city staff collected 7,784 pieces of trash at 59 on-land sites in neighborhoods (San Jose 2013d). Single-use plastic bags totaled 409, which equated to $5.3 \%$ of the litter collected in 2010 (San Jose 2013d). Between the two surveys, 15,701 items of litter were collected with 796 items being single-use plastic bags (San Jose 2013d). The total amount of plastic bags accounted for $5.1 \%$ of all litter collected during these two surveys (San Jose 
2013d). Table 12 on page 65 lists in detail how many of each bag type was collected during the site surveys in 2010. The accompanying pie chart in Figure 13 on page 65 provides a visual representation of this data table.

\section{Table 10: On-Land Litter Survey Results}

\begin{tabular}{|c|c|c|c|c|}
\hline Date & Pre Ban Results & Date & Post Ban Results & $\%$ Change \\
\hline \multicolumn{4}{|c|}{ CSJ Targeted Litter Survey } & \\
\hline 2009 & $\begin{array}{l}48 \text { sites, } 7,917 \text { pieces of } \\
\text { trash; } 387 \text { retail bags } \\
\text { collected, } 4.9 \% \text { of litter }\end{array}$ & 2012 & $\begin{array}{l}31 \text { sites, } 3679 \text { pieces of trash; } \\
76 \text { retail bags collected, } 2.1 \\
\% \text { of litter }\end{array}$ & \\
\hline 2010 & $\begin{array}{l}59 \text { sites; } 7,784 \text { pieces of } \\
\text { trash; } 409 \text { retail bags } \\
\text { collected, } 5.3 \% \text { of litter }\end{array}$ & & & \\
\hline Total: & $\begin{array}{l}107 \text { sites; } 15701 \text { pieces of } \\
\text { trash, } 796 \text { retail bags } \\
\text { collected, } 5.1 \% \text { of the litter }\end{array}$ & Total: & $\begin{array}{l}31 \text { sites; } 3679 \text { pieces of } \\
\text { trash, } 76 \text { retail bags } \\
\text { collected, } 2.1 \% \text { of the litter }\end{array}$ & $-59 \%$ \\
\hline
\end{tabular}

Source: San Jose 2013d 
Table 11: San Jose On-Land Litter Assessment, 2009

(48 Sites Surveyed)

\begin{tabular}{|c|c|c|}
\hline Bag Type & Total Bags Counted & Percentage of Litter \\
\hline PLASTIC RETAIL BAGS & 387 & $4.9 \%$ \\
\hline PAPER RETAIL BAGS & 22 & $0.3 \%$ \\
\hline PAPER BAGS (FAST FOOD) & 76 & $1.0 \%$ \\
\hline $\begin{array}{l}\text { PLASTIC BAGS (NOT } \\
\text { RETAIL) }\end{array}$ & 225 & $2.8 \%$ \\
\hline PAPER BAGS (NOT RETAIL) & 91 & $1.1 \%$ \\
\hline ZIPPER BAGS/ SANDWICH & 31 & $0.4 \%$ \\
\hline Total & 831 & $10.5 \%$ \\
\hline
\end{tabular}

Retail paper and plastic bags combined for $5.2 \%$ of all litter collected during the 2009 on-land litter surveys (San Jose 2012b).

Figure 12: San Jose On-Land Litter Assessment Proportions of Bag Sub Category, 2009

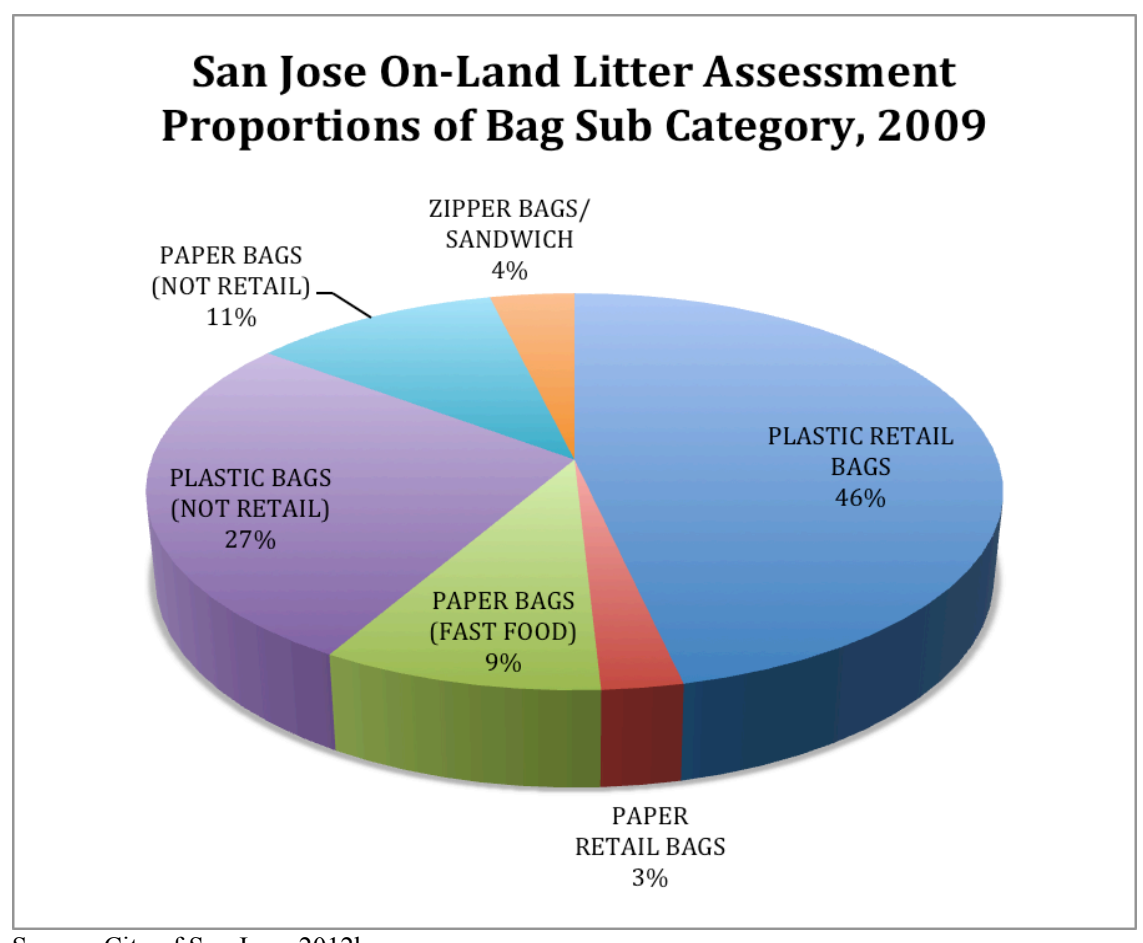

Source: City of San Jose, 2012b 
Table 12: San Jose On-Land Litter Assessment, 2010 (59 Sites Surveyed)

\begin{tabular}{|c|c|c|}
\hline Bag Type & Total Bags Counted & Percentage of Litter \\
\hline PLASTIC RETAIL BAGS & 409 & $5.3 \%$ \\
\hline PAPER RETAIL BAGS & 36 & $0.5 \%$ \\
\hline PAPER BAGS (FAST FOOD) & 49 & $0.6 \%$ \\
\hline $\begin{array}{l}\text { PLASTIC BAGS (NOT } \\
\text { RETAIL) }\end{array}$ & 159 & $2.0 \%$ \\
\hline PAPER BAGS (NOT RETAIL) & 51 & $0.6 \%$ \\
\hline ZIPPER BAGS/ SANDWICH & 48 & $0.6 \%$ \\
\hline Total & 751 & $9.6 \%$ \\
\hline
\end{tabular}

Retail paper and plastic bags combined for $5.8 \%$ of all littered collected during the 2010 onland litter surveys (San Jose 2012b).
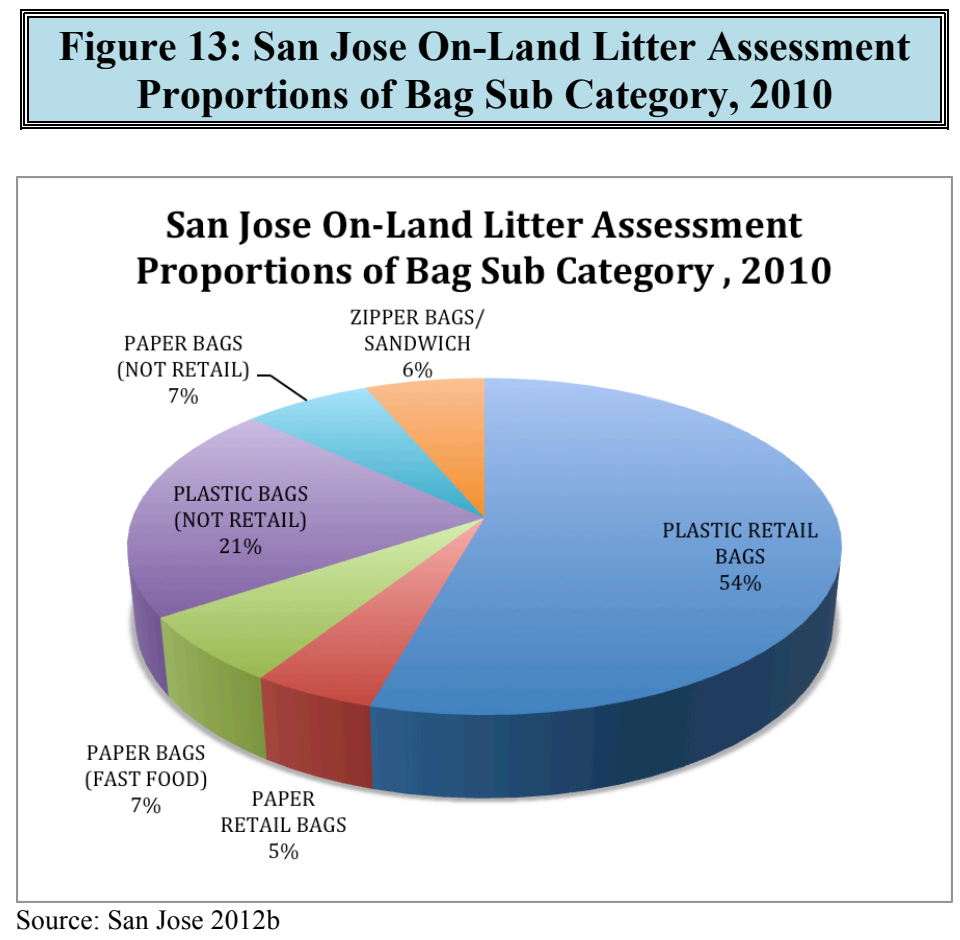

Following implementation of the BYOB Ordinance on January 1, 2012, city staff conducted litter surveys at 31 on-land sites in San Jose neighborhoods to measure the ordinance's impact during the eleven-month period between January and November 2012 (San Jose 2012b, San Jose 2013d). City staff gauged the BYOB Ordinance's impact on trash reduction by examining the litter collected from creeks, rivers, storm drain catch basins, and neighborhood 
sidewalks. Surveys at creeks were performed at standardized lengths of 300 feet (San Jose 2012b). Surveys in neighborhoods were performed on sidewalks in 100-foot sections (San Jose 2012b). City staff collected 3,679 garbage items from the 31 sites. Seventy-six "retail bags" were gathered accounting for $2.1 \%$ of all the litter collected during the 2012 surveys (San Jose 2013d). Table 13 lists in detail how many of each bag type was collected during the site surveys in 2012. The accompanying pie chart in Figure 14 illustrates the data in Table 12.

\section{Table 13: San Jose On-Land Litter Assessment, 2012 31 Sites Surveyed}

\begin{tabular}{|c|c|c|}
\hline Bag Type & Total Bags Counted & Percentage of Litter \\
\hline PLASTIC RETAIL BAGS & 76 & $2.1 \%$ \\
\hline PAPER RETAIL BAGS & 26 & $0.7 \%$ \\
\hline PAPER BAGS (FAST FOOD) & 14 & $0.4 \%$ \\
\hline $\begin{array}{l}\text { PLASTIC BAGS (NOT } \\
\text { RETAIL) }\end{array}$ & 58 & $1.6 \%$ \\
\hline PAPER BAGS (NOT RETAIL) & 15 & $0.4 \%$ \\
\hline ZIPPER BAGS/ SANDWICH & 24 & $0.7 \%$ \\
\hline Total & 213 & $5.8 \%$ \\
\hline
\end{tabular}

Retail paper and plastic bags combined for $2.8 \%$ of all littered collected during the 2012 onland litter surveys (San Jose 2012b).

\section{Figure 14: San Jose On-Land Litter Assessment} Proportions of Bag Sub Category, 2012

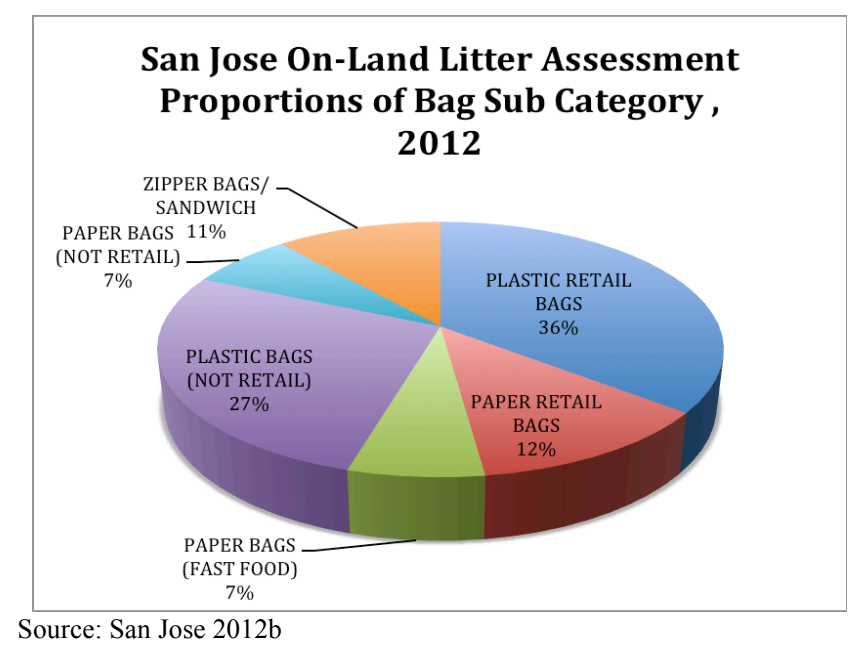


In addition, city staff frequently evaluated storm drains fitted with catch basins to measure how often plastic bags gathered in San Jose's storm drain system (San Jose 2012b). City staff noted and collected trash items from catch basins four separate times prior to implementation. Two surveys occurred after ordinance implementation in 2012. The first survey occurred in January while the other survey occurred in April (San Jose 2013d). San Jose staff included the January survey results with the pre-ordinance survey results in the Bag Ban Metrics table. This research is including the January survey results with the post-ordinance data since this survey occurred the same month the BYOB ordinance became effective.

During fiscal year 2008-2009, city staff surveyed 45 catch basins and collected 81 retail plastic bags, which equated to 1.8 bags per site. One year later (FY 2009-10), staff from the Santa Clara Valley Urban Runoff Pollution Prevention Program (SCVURPPP) collected 72 retail plastic bags from the same amount of catch basins (45) as the previous year. SCVURPPP staff noted 1.6 bags per site, which is a 12-pecent reduction from the previous year (San Jose 2013d). SCVURPPP is comprised of 13 cities and towns in the Santa Clara Valley, including San Jose, in partnership with the County of Santa Clara and the Santa Clara Valley Water District. These member agencies share a common National Pollutant Discharge Elimination System (NPDES) permit per the Clean Water Act (1972). Table 14 on page 68 provides in detail the reduction of plastic bags in city storm drains.

San Jose city staff conducted two litter surveys in 2011 to further measure the extent of bag litter in city storm drain catch basins. In May 2011, city staff observed 16 bags in 31 catch basins, which averaged to 0.52 bags per site. A subsequent survey occurred in September 2011 and resulted in 50 bags in 65 catch basins equaling 0.77 bags per site (San Jose 2013d). Survey data from 2011 reveals an average of 3.6 bags per site (San Jose 2013d). In January 2012, shortly 
after ordinance implementation, city staff noted 20 bags in 62 catch basins averaging 0.32 bags per site (San Jose 2013d). In April 2012, city staff observed nine bags in 69 catch basins resulting in 0.13 bags per site (San Jose 2013d). The total number of bags from the January and April surveys equaled 29, which averaged 0.4 bags per inlet (San Jose 2013d). Table 14 shows the results of the various storm drain surveys.

\section{Table 14: Storm Drain Trash Characterization}

\begin{tabular}{|c|c|c|c|c|}
\hline Date & Pre Ban Results & Date & Post Ban Results & $\%$ Change \\
\hline \multicolumn{4}{|c|}{ Storm Drain Trash Characterization } & \\
\hline FY08/09 & $\begin{array}{l}\text { (San Jose) } 45 \text { catch basins, } 81 \\
\text { bags, } 1.80 \text { bags per site }\end{array}$ & & & \\
\hline FY09/10 & $\begin{array}{l}\text { (SCVURPPP) } 45 \text { catch basins, } \\
72 \text { bags, } 1.60 \text { bags per site }\end{array}$ & & & \\
\hline 05/11 & $\begin{array}{l}31 \text { catch basins, } 16 \text { bags, } 0.52 \\
\text { bags per site }\end{array}$ & $04 / 12$ & $\begin{array}{l}69 \text { catch basins, } 9 \text { bags, } \\
0.13 \text { bags per site }\end{array}$ & \\
\hline $09 / 11$ & $\begin{array}{l}65 \text { catch basins, } 50 \text { bags, } 0.77 \\
\text { bags per site }\end{array}$ & & & \\
\hline $01 / 12$ & $\begin{array}{l}62 \text { catch basins, } 20 \text { bags, } 0.32 \\
\text { bags per site }\end{array}$ & & & \\
\hline Total: & $\begin{array}{l}2011 \text { average rate of } 3.6 \\
\text { bags/inlet/year }\end{array}$ & Total: & $\begin{array}{l}2012 \text { average rate of } \\
0.4 \text { bag/inlet/year. }\end{array}$ & $-89 \%$ \\
\hline
\end{tabular}

Source: San Jose 2013d

City staff also visited local creeks and rivers in 2010 and 2011 to understand litter's impact in San Jose's water sources. In 2010, city staff noted 670 retail bags at five sites, which represented $12.2 \%$ of all litter collected (5,491 pieces) (San Jose 2013d). One year later, staff observed 1,367 retail bags at 10 sites, which represented $8.2 \%$ of all litter collected (16,670 pieces) (San Jose 2013d). In sum, 2,037 retail bags accounted for $9.2 \%$ of the total litter collected (22,161 pieces) during these two surveys (San Jose 2013d). City staff surveyed ten creek and river sites in 2012 and 2013. City staff collected 513 retail plastic bags in 2012, which accounted for $3.7 \%$ of all litter collected (13,864 pieces) (San Jose 2013d). A year later, city staff noted 190 plastic retail bags at the same ten sites. This amount of bags represented $2.8 \%$ of all 
garbage collected (6,785 pieces) during the 2013 survey (San Jose 2013d). In sum, the two postordinance surveys totaled 20,649 garbage items with 703 items being retail plastic bags (San Jose 2013d). Retail plastic bags accounted for $3.4 \%$ of all litter collected during these two postordinance surveys. Table 15 lists in detail the plastic bag litter data from creek cleanup data.

\section{Table 15: Creek and River Cleanup Characterization}

\begin{tabular}{|c|c|c|c|c|}
\hline Date & Pre Results & Date & Post Ban Results & $\%$ Change \\
\hline \multicolumn{4}{|c|}{ Hot Spot Trash Characterization } & \\
\hline 2010 & $\begin{array}{l}5 \text { sites: } 670 \text { bags; } 12.2 \% \text { of total } \\
\text { litter pieces collected }\end{array}$ & 2012 & $\begin{array}{l}10 \text { sites: } 513 \text { bags; } 3.7 \% \text { of } \\
\text { total litter pieces collected }\end{array}$ & \\
\hline 2011 & $\begin{array}{l}10 \text { sites: } 1,367 \text { bags; } 8.2 \% \text { of total } \\
\text { litter pieces collected }\end{array}$ & 2013 & $\begin{array}{l}10 \text { sites: } 190 \text { bags; } 2.8 \% \text { of } \\
\text { total litter }\end{array}$ & \\
\hline Total: & $\begin{array}{l}15 \text { sites, } 2,037 \text { bags; } 9.2 \% \text { of } \\
\text { total litter }\end{array}$ & Total: & $\begin{array}{l}10 \text { sites, } 513 \text { bags; } 2.5 \% \\
\text { of total litter }\end{array}$ & $-73 \%$ \\
\hline
\end{tabular}

Source: San Jose 2013d

Compared to litter data collected in 2009 and 2010, prior to the BYOB Ordinance's

implementation, storm drain bag litter decreased by $89 \%$. Plastic bag litter declined by $73 \%$ in creeks and rivers while a 59\% decrease occurred in neighborhoods (San Jose 2012b). The staff report entitled Bring Your Own Bag Implementation Results states, "Numerous staff surveys, observations, and enforcement efforts demonstrate that the Bring Your Own Bag Ordinance has been successful at affecting community norms towards shopping with reusable bags and reducing single-use plastic bag litter in City creeks and streets" (San Jose 2012b, 1-2). Furthermore "All of the key indicators monitored by staff show downward trends in [the] presence of single-use plastic bags in street, storm drain, and creek litter, and an upward trend in the use of reusable bags by shoppers" (San Jose 2012b, 3). 


\section{Store Exit Survey Results}

As for bag usage among consumers, the average number of bags used per customer decreased from almost three (2.95 bags) to less than one bag (0.85 bags) (San Jose 2012c). The average number of single-use bags (paper and plastic) decreased from 2.86 per customer before implementation to 0.3 bags by October 2012 (San Jose 2012c). A total of 28 stores were surveyed across three separate surveys in 2009 and 2010 (San Jose 2013d). The first survey occurred at seven stores in the spring of 2009. The second survey occurred at ten stores in the winter of 2010 with the third survey occurring at 11 stores in the summer of 2010 (San Jose 2013d). Two exit surveys occurred after ordinance implementation in February and October 2012 (San Jose 2012b). City employees noted the amount and type of bags, or lack of bags, retail customers carried their purchases in. These observations occurred in one-hour segments at selected retail locations. Exit survey data indicated that the use of reusable bags increased from four percent prior to implementation to about 62 percent after implementation of the BYOB ordinance. In addition, the proportion of consumers carrying items from stores without bags increased from 12.9 percent to 43 percent (San Jose 2012c).

In the spring 2009 survey, city staff observed 1,057 customers at seven stores who used a total of 3,298 bags of three types (San Jose 2012c). The three types of bags included single-use plastic, paper and reusable bags. The total number of each bag is accompanied by the proportion of each bag type relative to the total number of bags observed. Most of the bags observed were plastic bags at 2,542 (77.1\%), followed by 641 paper bags $(19.4 \%)$ and 115 reusable bags (3.5\%) (San Jose 2012c). Sixty customers (5.7\% of all customers observed) were observed not using any bags (San Jose 2012c). The average number of bags per customer was 3.12 bags while single-use plastic and paper bags averaged 3.0 bags per customer (San Jose 2012c). 
In the winter of 2010 , city staff observed 705 customers at 10 stores who used 3,883 total bags (San Jose 2012c). Like the 2009 survey, single-use plastic bags were the most common bag type observed at 3,598 bags $(92.7 \%)$, followed by 208 paper bags $(5.4 \%)$ and 77 reusable bags (2.0\%) (San Jose 2012c). City staff observed 67 customers not using bags, which equated to $9.5 \%$ of all customers observed (San Jose 2012c). The average number of bags per customer was 5.51 bags while single-use plastic and paper bags averaged 5.4 bags per customer (San Jose 2012c). Table 16 on page 71 shows the results of the store exit surveys.

\section{Table 16: Visual Bag Observations}

\begin{tabular}{|c|c|c|c|}
\hline Date & Results & Date & Post Ban Results \\
\hline \multicolumn{4}{|c|}{ Visual Bag Observations } \\
\hline 2009 & $\begin{array}{l}1,057 \text { customers, } 7 \text { stores; } \\
\text { average of } 3.1 \text { bags per } \\
\text { customer, } 3 \% \text { of bags were } \\
\text { reusable, } 16.8 \% \text { no bag }\end{array}$ & $\begin{array}{c}2012 \\
\text { (Spring) }\end{array}$ & $\begin{array}{l}1068 \text { customers, } 7 \text { stores; average of } \\
.84 \text { bags per customer, } 61 \% \text { of bags } \\
\text { were reusable. } 41 \% \text { of customers not } \\
\text { using a bag. }\end{array}$ \\
\hline $\begin{array}{c}2010 \\
\text { (Winter) }\end{array}$ & $\begin{array}{l}705 \text { customers, } 10 \text { stores: an } \\
\text { average of } 5.6 \text { bags per } \\
\text { customer, } 3 \% \text { of bags were } \\
\text { reusable, } 9.5 \% \text { no bag }\end{array}$ & $\begin{array}{l}2012 \\
\text { (Fall) }\end{array}$ & $\begin{array}{l}1105 \text { customers, } 7 \text { stores; average of } \\
.87 \text { bags per customer, } 67.2 \% \text { of bags } \\
\text { were reusable. } 47.6 \% \text { of customers not } \\
\text { using a bag. }\end{array}$ \\
\hline $\begin{array}{c}2010 \\
\text { (Summer) }\end{array}$ & $\begin{array}{l}1,107 \text { customers, } 11 \text { stores: } \\
\text { average of } 1.2 \text { bags per } \\
\text { customer, } 5.6 \% \text { of bags were } \\
\text { reusable, } 27.2 \% \text { no bag }\end{array}$ & & \\
\hline Total: & $\begin{array}{l}2,869 \text { customers, } 28 \text { stores, } \\
\text { avg. } 3 \text { bags per customer, } \\
3.6 \% \text { of bags reusable, } 12.9 \% \\
\text { of customers not using a bag. }\end{array}$ & Total: & $\begin{array}{l}2173 \text { customers, } 14 \text { stores; average } \\
\text { of } .85 \text { bags per customer, } 64.4 \% \text { of } \\
\text { bags were reusable. } 43.5 \% \text { of } \\
\text { customers not using a bag. }\end{array}$ \\
\hline
\end{tabular}

Source: San Jose 2013d

In the summer of 2010 , city staff observed 1,107 customers at 11 stores who used a total of 1,296 bags (San Jose 2012c). Like the two previous surveys single-use plastic bags were the most frequently observed bag type at 1,064 bags (82.1\%) followed by 159 paper bags $(12.3 \%)$ 
and 73 reusable bags (5.6\%) (San Jose 2012c). City staff observed 243 customers carrying items without bags, which equated to $22.0 \%$ of all customers observed (San Jose 2012c). The average number of bags per customer was 1.2 bags while single-use plastic and paper bags averaged 1.1 bags per customer (San Jose 2012c).

In February 2012, city staff observed 1,068 customers at seven stores who used a total of 895 bags (San Jose 2012c). The most frequently observed bag type was reusable bags at 550 (61.5\%) followed by 317 paper bags (35.4\%) and 28 single-use plastic bags (3.1\%) (San Jose 2012c). City staff observed 419 customers carrying goods without bags representing $39.2 \%$ of all customers observed (San Jose 2012c). The average number of bags per customer equaled 0.84 bags while single-use plastic and paper bags averaged 0.32 bags (San Jose 2012c).

In October 2012, city staff observed 1,105 customers at seven stores who used a total of 959 bags (San Jose 2012c). Reusable bags were the most common bag type observed at 644 bags (67.2\%) followed by 300 paper bags (31.3\%) and 15 single-use plastic bags (1.6\%) (San Jose 2012c). City staff observed 526 customers carrying their purchases without bags accounting for 47.6 of all customers observed (San Jose 2012c). The average number of bags totaled 0.87 bags while single-use plastic and paper bags averaged 0.29 bags (San Jose 2012c).

In addition to observing consumers' bag choices, City staff also conducted "visual business observations at randomly selected retailers" of various types and sizes throughout San Jose (San Jose 2012, 7). Following visits in February and October 2012, less than four percent of businesses provided non-compliant single-use plastic bags to customers (San Jose 2012b). Between 55 and 63 percent of stores offered recyclable paper bags while the proportion of stores offering reusable plastic bags at no charge increased from 15 percent to 29 percent during this eight-month period (San Jose 2012b). 
Moreover, California Environmental Quality Act (CEQA) consultants conducted a phone survey of grocery stores located in San Jose in November 2012 to further assess bag usage among consumers. Sixteen stores responded to the survey with eight stores reporting an increase and two stores saying usage did not change (San Jose 2013c). Only two store representatives (Trader Joe's and Lunardi's) provided "specific numbers" (San Jose 2013c). Also, "seven other stores were contacted, but four had no basis for comparison, and three stores had not offered paper bags" (San Jose 2013c, 8). Since the BYOB ordinance does not require grocery stores to report paper bag use, "it cannot be proven conclusively that there has been a substantial decrease in single-use paper bags...[However,] It can be deduced from available information...that there has NOT been a significant increase" (San Jose 2013c).

San Jose policy makers amended the City’s Final Environmental Impact Report (FEIR) regarding the Single-Use Carryout Bag Ordinance per CEQA policy in July 2013. Policy makers amended the ordinance because new information became available following the results of the litter surveys and visual business observations in 2012. The City of San Jose cited CEQA policy, which acknowledges, "previously unknown information can arise... between the date an environmental document is completed and the date a project is fully implemented" (San Jose 2013c, 2).

The ordinance's original language called for an increase to the minimum fee charged for recyclable paper bags from 10 cents to 25 cents on January 1, 2014 (San Jose 2012a). The basis for this fee increase was to restrict any increased use in single-use paper bags due to the banning of single-use plastic bags (San Jose 2013c). However, based on the implementation results gathered by city staff in 2012, the aforementioned assumption proved incorrect because "the 10 cent store charge is effective in changing customer behavior away from [using] disposable bags 
(San Jose 2013c). Therefore justifiably, "there is no longer any environmentally-based purpose for raising the fee to 25 cents...for single-use paper carryout bags with 40 percent recycled content because the 10 cent store charge is effective in changing customer behavior away from [using] disposable bags" (San Jose 2013c, 9). The addendum further states that, "Increasing the minimum fee "was only one of the tools identified for reducing reliance on single-use paper bags" (San Jose 2013c, 9).

Furthermore, a memorandum to the City of San Jose's Transportation and Environment Committee dated August 22, 2013, agrees with keeping the minimum bag fee charge at ten cents because of consumer trends regarding bag use. First, paper bag use did not increase among consumers while use of reusable bags did increase (San Jose 2013b, 3). The memorandum justifies this stance by stating, "Since the anticipated surge in demand for single-use paper bags did not materialize and observations indicate increasing use of reusable bags, staff believes the scheduled increase in the minimum charge for a recycled...paper bag is not necessary at this time..." (San Jose 2013b, 3). Second, shoppers' use of reusable bags resulted in positive impacts. For example the memorandum states, “The bag regulations have modified shoppers' behaviors as intended, resulting in a reduction in single-use plastic bag litter in City creeks and streets, reducing waste and improving recycling operations" (San Jose 2013b, 3).

The three recycling companies that serve San Jose tracked the amount of plastic film (i.e. single-use plastic bags from retailers) that accumulated at their facilities following enactment of the ordinance. Two of the three companies noticed a significant decrease in the proportion of recyclable material that was plastic film. For example, California Waste Solutions (CWS), which collects recyclable materials for $80 \%$ of the City's single-family homes, "reported a $24 \%$ reduction in retail plastic bags (San Jose 2012b, 5). Green Waste Recovery, which collects waste 
from San Jose's multi-family residences, reported a 10-15 percent decline in the volume of plastic film (San Jose 2012b). The City's third recycling processor, Green Team, which collects recyclables from 20 percent of San Jose's single-family homes "has not seen a noticeable reduction in incoming plastic film or plastic bags" (San Jose 2012, 5). CWS reported "a significant reduction in the amount of plastic film" wrapped around recycling machinery (San Jose $2012 \mathrm{~b}, 5)$. As a result, CWS reported a " $35-50 \%$ reduction in downtime directly associated with the reduced presence of plastic bags / film" entering their facility (San Jose 2015, 5).

\section{Retail Bag Ordinance Survey Results}

The researcher surveyed municipal administrators throughout the nine-county San Francisco Bay Area to collect primary data related to the research questions posed earlier in this report. In sum, 44 public administrators at the county and city levels throughout the Bay Area were invited to participate in two surveys. Administrators from the county level were included in these surveys because many cities, especially smaller jurisdictions with less resources and funding, adopted county ordinances, and therefore, the county handles enforcement and data collection. Some of the prospective respondents invited to participate included in both survey groups were administrators employed with waste management agencies. The first survey was sent to 30 municipal administrators whose cities or counties had adopted a plastic bag ordinance between 2007 and 2014 while the other survey was sent to 14 public administrators whose cities had not adopted such an ordinance in the same time period. Both survey invitees and respondents and the jurisdictions they represent will remain anonymous as previously stated in this report and guaranteed by the researcher.

The first survey entitled Retail Bag Ordinance Survey (Adopter) intended to assess how successful city and county ordinances were in reducing trash in public spaces and waterways, 
and changing consumers' bag usage habits, as well as illustrate how plastic bag policies spread amongst Bay Area cities and counties (i.e. policy diffusion). Thirty Bay Area municipal administrators received this survey with 16 administrators responding to the survey equating to a $53.3 \%$ response rate. Thirteen of the 16 respondents completed the survey $(81.2 \%)$ while three (18.8\%) did not complete it. The second survey entitled Retail Bag Ordinance Survey (NonAdopter), intended to measure how successful non-adopter cities and counties were in affecting the previously mentioned criteria without an ordinance as a basis of comparison to their adopter counterparts. Fourteen public administrators from non-adopting cities and counties received the survey with eight completing the survey equaling a $57.1 \%$ response rate. These sample sizes may be considered small, but these respondents are experts in a growing field of public policy and thus most suitable for analysis.

\section{Adopter Survey Results}

\section{Background Information}

Thirty public administrators from cities and counties currently with plastic bag ordinances were invited to participate in a survey between February 23, 2015 and March 13, 2015. The survey's objectives were to measure the reasons for and impacts of adopting a reusable bag ordinance and or plastic bag ban. Initial background data based on the 16 respondents' answers revealed that 14 respondents $(87.5 \%)$ represented cities and counties that adopted ordinances after 2010, thus making them late adopters. These late adopters' ordinances were approved between 2012 and 2014. One respondent (6.25\%) was an early adopter while another did not indicate when their jurisdiction adopted its ordinance. Populations range between 1,458 and 850,000 people of the jurisdictions they represent. These numbers reflect three counties and ten cities with a mean population of 191,637 people and a median population of 
75,500 people. Seventy-five percent of respondents (12) stated that their community's ordinance is based on another jurisdiction's ordinance while 25 percent (4) stated that their local ordinance was not based on another ordinance. Ten respondents (62.5\%) indicated that their city has a storm drain permit with the San Francisco Bay Regional Water Quality Control Board. One respondent's (6.3\%) jurisdiction did not have such a permit while five respondents $(31.3 \%)$ selected the "Don't know / not applicable" choice.

\section{Ordinance Impacts}

Of the ten respondents who stated that their jurisdiction has a storm drain permit, four said their city did not face any challenges meeting the San Francisco Water Board's 40\% trash reduction mandate by July 1, 2014. However, four respondents stated that their jurisdiction faced challenges meeting the reduction requirement. Two respondents referred the researcher to other agencies regarding this topic such as waste management and storm water pollution control agencies because these respondents did not have this information available. The six respondents that indicated their jurisdiction did not have a storm water permit were excused from responding to this question.

Respondents whose cities faced challenges meeting the $40 \%$ trash reduction target said limited staffing and increased costs to cover cleaning of streets and storm drains, as well inspecting storm drain components and trash capture devices were not feasible. Another respondent indicated litter from neighboring cities impacted efforts to meet the reduction requirement by saying, "Litter comes from a variety of sources, including arterial streets used by [the] region and retail stores located on city borders." Another respondent whose city also faced challenges meeting the reduction target said their municipality met the Water Board's litter reduction target by saying the City "accomplished all the goals listed on our Trashload Reduction 
Plan according to the proposed timeline. However, the Water Board deemed this particular city to be in 'Mitigated Non-Compliance."' This particular city is awaiting a response from the San Francisco Water Board following a hearing where the City justified its calculations related to the mandate.

Respondents were also surveyed about where single-use plastic bags accumulated in their communities and how successful trash reduction efforts transpired with an emphasis on singleuse plastic bags. Respondents also answered questions related to costs of litter collection following implementation. Thirteen public administrators responded to this series of questions. Just over $69 \%$ of respondents said single-use plastic bag litter accumulates in public space while more than $15 \%$ said retail bags did not accumulate in public space. Slightly more than $15 \%$ chose the "Don't know / Not applicable" option. More than $61 \%$ of respondents said creeks are the most common location where retail plastic bags are found while $15.4 \%$ said single-use bags do not appear in creeks. Just over 23\% of respondents selected the "Don't know / Not applicable" choice. More than $46 \%$ of respondents said streams and waterways are the most common location for plastic bags to be found. For the purposes of this research, streams are defined as narrow rivers not used for travel while waterways are considered canals, rivers or other routes used for travel. See Appendix A for respondents' responses to all survey questions.

In response to this series of questions, $75 \%$ of respondents indicated that reducing the presence of single-use plastic bags in creeks, streams, rivers and waterways was successful while one respondent $(8.3 \%)$ said such efforts were very successful. Two respondents $(16.7 \%)$ said reducing the accumulation of plastic bags in these areas was somewhat successful. None of the 12 respondents who answered this question indicated their community's efforts regarding this aspect were unsuccessful. Of the 11 public administrators who responded, over $72 \%$ of 
respondents said their communities' reducing the amount of single-use plastic bags in storm drains was successful while one respondent (9.1\%) said their city or county's efforts were very successful. One respondent indicated that their community was somewhat successful while another respondent said their community was not successful in reducing the amount of retail plastic bags in storm drains.

None of the 12 public administrators who responded to the question asking how much money their city spends on litter abatement and collection related to single-use plastic bags could provide either an estimated or exact amount. One respondent clarified their choice by saying, "Cost is just part of [the] overall public works street sweeping and maintenance budget." However, over $55 \%$ of respondents indicated that the reduction in litter collection and abatement costs since their communities implemented their ordinances was successful. Two respondents (22.2\%) said cost reductions were somewhat successful while two others said such reductions were not successful.

\section{Stakeholder Data}

Based on their perceptions, public administrators in adopting jurisdictions were asked how favorable, unfavorable or indifferent various stakeholder groups' attitudes would be in response to a plastic bag ban and or reusable bag ordinance. Twelve (75\%) of the 16 survey participants responded to this series of questions. Respondents were also given the "Don't know / Not applicable" option in case they did not have enough information to make an assessment about a particular stakeholder group. Of the twelve public administrators who responded to this survey item, 100\% said the mayor and city council had a favorable attitude toward a reusable bag ordinance and or plastic bag ban followed by the city manager at $83.3 \%$. One respondent said their city manager had an unfavorable attitude while another said their city manager was 
indifferent. Exactly $75 \%$ of respondents said their public works and environmental departments had a favorable attitude. Figure15 on page 80 provides a detailed look at these stakeholders' perceived attitudes related to this policy area.

Respondents perceived $50 \%$ of consumers to have a favorable attitude while one-third said consumers appeared to be indifferent and $16.7 \%$ did not know consumers' attitudes toward this issue. Over $41 \%$ of respondents surveyed said that retailers had a favorable attitude, $33.3 \%$ were indifferent, $16.7 \%$ had an unfavorable attitude and $8.3 \%$ did not know retailers' attitudes toward this issue. Twenty-five percent of respondents believed restaurateurs have a favorable attitude toward a plastic bag ban and or reusable bag ordinance. More than $8 \%$ of respondents believe this stakeholder group has an unfavorable view, while $25 \%$ believe this group is indifferent and 41.7\% selected the "Don't know / Not applicable" choice.

\section{Figure 15: Stakeholder Perceptions}

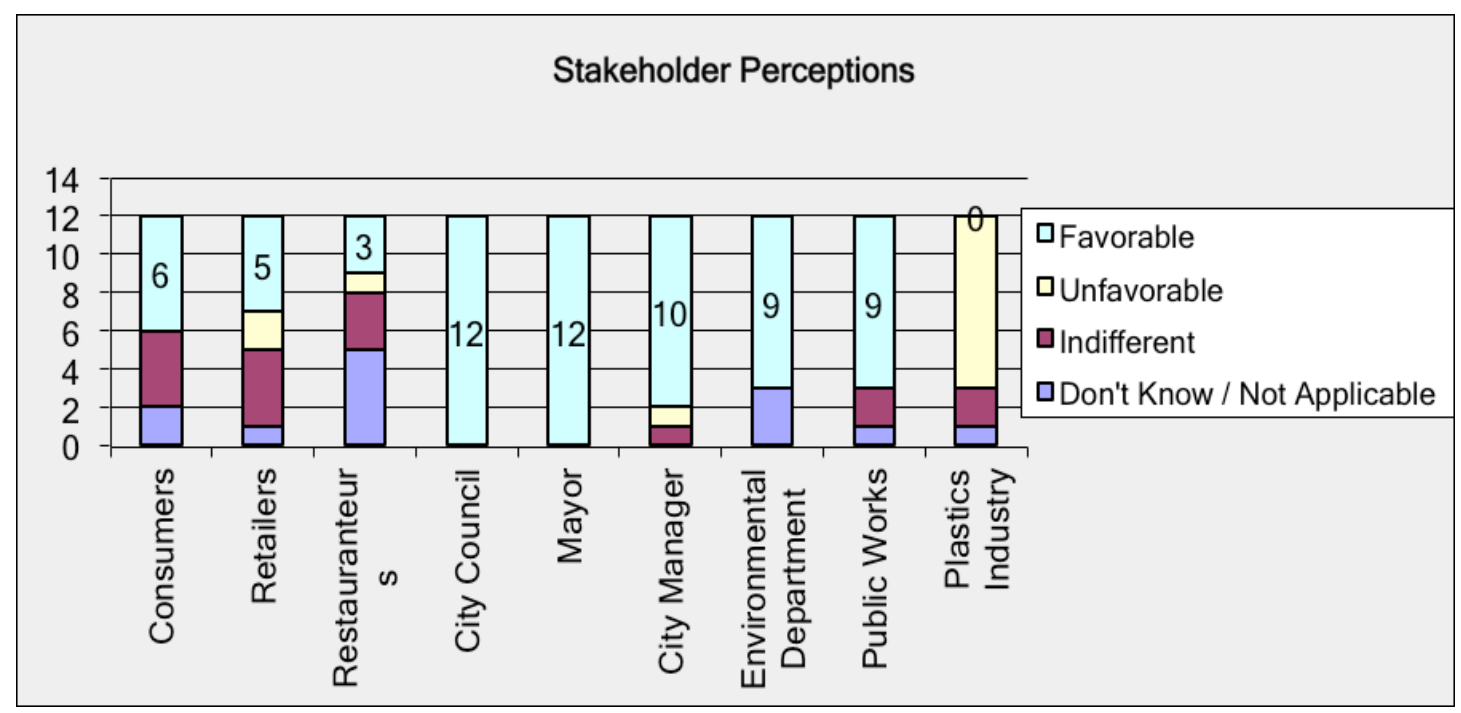

Exactly $75 \%$ of respondents believe the plastics industry has an unfavorable attitude toward a reusable bag ordinance and or plastic bag ban. Two respondents (16.7\%) perceive this stakeholder group to be indifferent toward such a policy while one respondent $(8.3 \%)$ does not 
know the plastic industry's attitude regarding this policy. No respondent indicated that the plastics industry holds a favorable attitude toward reusable bag / plastic bag ban policies.

Based on their experience, respondents were asked if citizens in their communities believed single-use plastic bags are an environmental danger and that reusable bags are the best substitute available. Of the 13 public administrators $(81.3 \%)$ who answered this question, ten respondents (76.9\%) agreed while three respondents (23.1\%) chose the "Don't know / Not Applicable" option.

\section{Policy Diffusion}

Respondents were asked what challenges their city or county faced as either an early adopter or late adopter of a retail plastic bag policy. Twelve respondents (75\%) shared their experiences in this portion of the survey. Four respondents, three of which whose communities were late adopters, said their ordinances were tied to either a county ordinance or part of a regional effort involving multiple counties. Having a county ordinance in place made the adoption process at the city level easier. For example, one respondent commented that few challenges occurred because "Adopting regionally help to provide a level playing field for retailers and less confusion for customers." However, another respondent whose city adopted a county ordinance said the challenge was reassuring stakeholders that the County would fund outreach, inspection, and compliance, as well as make enforcement non-punitive. Another respondent from the county level whose community is a late adopter said finding real data to support an ordinance's environmental benefits and economic impacts.

Other challenges included lack of support from some councilmembers; the city manager and chamber of commerce slowed the adoption process for another late-adopting city. A county administrator said reaching a consensus on consistent ordinance language among "all councils 
and boards" was the most challenging aspect of crafting an ordinance for a late-adopting agency. The threat of lawsuits and lobbying by the interests supporting single-use plastic bag manufacturers represented the biggest challenge for an early-adopting Bay Area community. As an early adopter this particular community dealt with a lawsuit, but learned from later adopters that drafting an environmental impact report was beneficial to the adoption process.

However, according to one respondent, court decisions after 2010 ruled that plaintiffs suing cities over plastic bag ordinances were responsible for covering costs, too. Between 2011 and 2012, superior courts in San Francisco, Marin County, Los Angeles and San Luis Obispo upheld municipal plastic bag ordinances. These same ordinances were later upheld in state district courts of appeal while petitions to the California State Supreme Court to overturn appellate decisions were denied (Californians Against Waste 2014). Late adopting cities benefitted from these decisions because they provided guidance regarding ordinance adoption and environmental review. One respondent from a late adopting city said residents wondered why their decision makers had not adopted an ordinance sooner.

\section{Policy Learning}

Respondents were asked what their decision and policy makers learned from other jurisdictions when crafting their plastic bag policies. Twelve of 16 respondents answered this question. A plurality of five respondents (41.6\%) learned that regional collaboration was beneficial to adopting and implementing plastic bag ordinances. Specifically, adopting an ordinance that is similar to ordinances in neighboring cities benefits the implementation process. Implementing a countywide ordinance that applies to unincorporated sections and allows city leaders to decide for themselves whether to adopt or not do so. One respondent said his city's decision makers adopted a county ordinance that was implemented and enforced at the county 
level, thus making adoption easy. One respondent said, "Achieving critical mass in a region is better than going it alone. Knowing where the money is coming from for outreach, training, inspection and compliance [are] important for stakeholder buy-in." Reassuring citizens that enforcement is penalty free and how compliance benefits the community are additional approaches to gaining support from stakeholders.

Two other Bay Area public administrators said their city leaders learned to include additional stakeholders. For example, one particular respondent said her city's policy and decision makers learned "to consider bag providers that are not normally thought of as retailers, such as restaurants [that] have a large amount of take-out orders." Another respondent said her city's policy and decision makers learned to include exemptions for restaurants that offer prepared food. Furthermore, this particular city's policy included bag fee exemptions for recipients of Supplemental Nutritional Assistance Program (SNAP) and Women, Infants and Children (WIC) benefits. Imposing a bag fee gives consumers a choice in limiting their environmental impact by reducing the amount of bags they use upon checkout. In addition, eight of 13 respondents (61.5\%) indicated that Women, Infants and Children (WIC) and Supplemental Nutritional Assistance Program (SNAP) recipients currently are not required to pay minimum bag fees to obtain reusable and recyclable paper bags. Three respondents (23.1\%), however, said that WIC and SNAP beneficiaries are subject to minimum bag fees.

Neighboring cities with similar policies in place can affect another city's willingness to follow suit. For example, ten of the thirteen respondents $(76.9 \%)$ indicated that neighboring cities with plastic bag policies by virtue of their geographic proximity either had a significant or very significant impact on their city's decision to adopt a bag policy. Two respondents (15.4\%) said neighboring cities had a somewhat significant impact on their city's decision to adopt while 
one respondent (7.7\%) said the impact was not significant. Figure 16 on page 84 provides a detailed look at this aspect of policy diffusion regarding retail bag policy. Ten respondents also said their cities' decision makers, during the policy making process, did not believe their cities would experience economic disadvantages by prohibiting retailers from distributing single-use plastic bags. Three respondents (23.1\%) said their decision makers believed economic disadvantages would result from implementation. One respondent cited businesses unwilling to hang their shingles due to the bag policy as an economic disadvantage.

\section{Figure 16: Impact of Neighboring Cities on Policy Adoption}

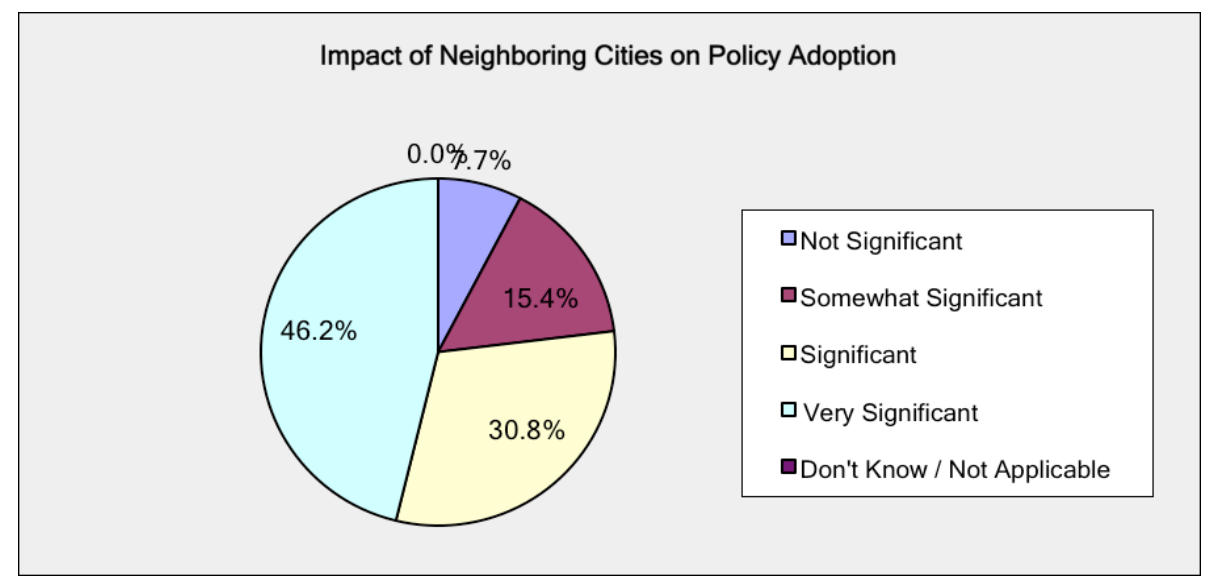

Five respondents (38.5\%) said their cities amended their original bag ordinances while eight respondents (61.5\%) said their cities have not done so. All five respondents from cities with amended ordinances discussed the changes with two respondents $(12.5 \%)$ saying their cities' decision makers decided not to increase the minimum bag fee from ten cents to 25 cents. Another respondent's colleagues instituted a minimum bag fee of ten-cents at retail locations in 2012 and at food service vendors in 2013. One other respondent said her city's decision makers changed the ordinance's implementation date from 30 days after adoption to October 1, 2013 to give grocers and retailers time to use their remaining supplies of plastic bags. Eight respondents 
commented on how successful these amendments were following implementation. The researcher considers success as measured by full ordinance compliance by retailers and changing norms among consumers to where they use reusable bags upon checkout. Three respondents (37.5\%) said amendments were successful and two respondents (25\%) said the changes were very successful. Three respondents chose the "not applicable" option when rating success.

\section{Best Practices}

Twelve of the 16 respondents shared best practices related to adopting and implementing plastic bag ordinances. Half of these respondents listed early stakeholder outreach and education as the most important approach when crafting a plastic bag ordinance. Four of the respondents (25\%) agreed that regional collaboration allows neighboring cities to adopt ordinances with consistent language that makes implementation and compliance feasible. This approach reflects Karch's second cause for policy diffusion: imitation. With imitation, jurisdictions share a policyrelevant characteristic, which in this case is reducing litter within cities. Finally, four different practices were each listed by two respondents each $(12.5 \%)$. These four best practices included enforcement that is non-punitive and compliant based; applying the ordinance across all sectors (grocery, retail, and food service), positive messaging and charging a bag fee at the point-of-sale.

\section{Non-Adopter Survey Results}

\section{Background Information}

Fourteen public administrators from cities and counties currently without plastic bag ordinances were invited to participate in a survey between February 23, 2015 and March 13, 2015. This survey's objective was to learn the reasons for and the impacts of not adopting a reusable bag ordinance and or plastic bag ban. Eight public administrators (57.1\%) responded and completed the survey. A small sample size was surveyed because the number of 
communities without plastic bag policies is shrinking. The eight respondents represent Bay Area communities with populations ranging between 19,190 people and 116,000 people. Broken down statistically, the sample mean of the populations is almost 67,937 people while the median population is 75,000 people. This median population is only 500 people less than the median population of the communities represented in the adopter survey (75,500 people).

Six of the respondents said their communities have storm drain permits with the San Francisco Regional Water Quality Control Board while two respondents said their jurisdictions did not. All six respondents who indicated their communities have storm drain permits discussed challenges their communities faced meeting the Water Board's $40 \%$ storm drain trash load reduction by July 1,2014 . One respondent said her community did not meet the $40 \%$ reduction mandate, but this municipality will exceed the $40 \%$ requirement by July 1,2015 . Two respondents said they were unsure if their community met the requirement, but one of these respondents said the $40 \%$ reduction requirement was used to motivate specific retailers to collect trash in their parking lots. Two other respondents said their jurisdictions met the reduction target without any challenges while one respondent said this issue was not applicable.

\section{Litter Impacts}

All eight respondents indicated where in their communities single-use plastic bags accumulate. In this series of questions the results were the same for each category. For example, five respondents (62.5\%) said single-use plastic bags accumulated in creeks, streams, waterways and public spaces. On the contrary, one public administrator (12.5\%) said single-use plastic bags did not accumulate in these areas. Two public administrators (25\%) selected the "Don't know / Not Applicable" option for each category. For the purposes of this research, streams are defined 
as narrow rivers not used for travel while waterways are considered canals, rivers and other routes used for travel.

As for reducing the presence of single-use plastic bags in creeks, streams and waterways without an ordinance, half of the respondents said reduction efforts have been somewhat successful. One respondent (12.5\%) said reduction efforts have been successful and three respondents (37.5\%) chose the "Don't know / Not applicable" option. Interestingly enough, the same response distribution occurred when all eight respondents were asked how successful reducing single-use plastic bags in storm drains were without a plastic bag ban. Overall, ordinances are successful in reducing the presence of single-use plastic bags in creeks, streams, waterways and storm drains. By virtue of consumers using no bags at check out or reusing previously purchased bags, less litter appears in creeks, streams, waterways and storm drains.

\section{Stakeholder Data}

Based on their perceptions, public administrators in non-adopting jurisdictions were asked how favorable, unfavorable or indifferent various stakeholder groups' attitudes would be in response to a plastic bag ban and or reusable bag ordinance. All eight survey participants responded to this series of questions. Respondents were also given the "Don't know / Not applicable" option in case they did not have enough information to make an assessment about a particular stakeholder group. Seventy-five percent of respondents said the mayor, environmental department and consumers all had a favorable attitude toward a reusable bag ordinance and or plastic bag ban. More than $62 \%$ of respondents said the city manger and public works department had a favorable attitude. Half of the respondents said the city council had a favorable attitude followed by retailers at $25 \%$ and restaurateurs at $12.5 \%$. 
None of the respondents said the plastics industry had a favorable attitude toward such a policy. In fact, $62.5 \%$ of respondents said the plastics industry held an unfavorable attitude toward a plastic bag ban and or reusable bag ordinance. Half of the respondents believed restaurateurs did not favor a plastic bag ban while $25 \%$ said retailers were against such policy. One respondent (12.5\%) said the mayor and city council held an unfavorable view of this type of ordinance. Figure 17 on page 88 provides a detailed look at these stakeholders' perceived attitudes related to this policy area.

Three respondents (37.5\%) said the public works department held an indifferent attitude related to plastic bag bans and or reusable bag ordinances. Twenty-five percent of those polled indicated consumers, retailers and the city councils in their communities also held an indifferent view of this type of policy. One respondent said the city manager was indifferent towards such a policy. Based on their experience, respondents were asked if citizens in their communities believed single-use plastic bags are an environmental danger and that reusable bags are the best substitute available. Of the eight public administrators who answered this question, five respondents (62.5\%) agreed while three respondents (37.5\%) disagreed.

\section{Figure 17: Stakeholder Perceptions}

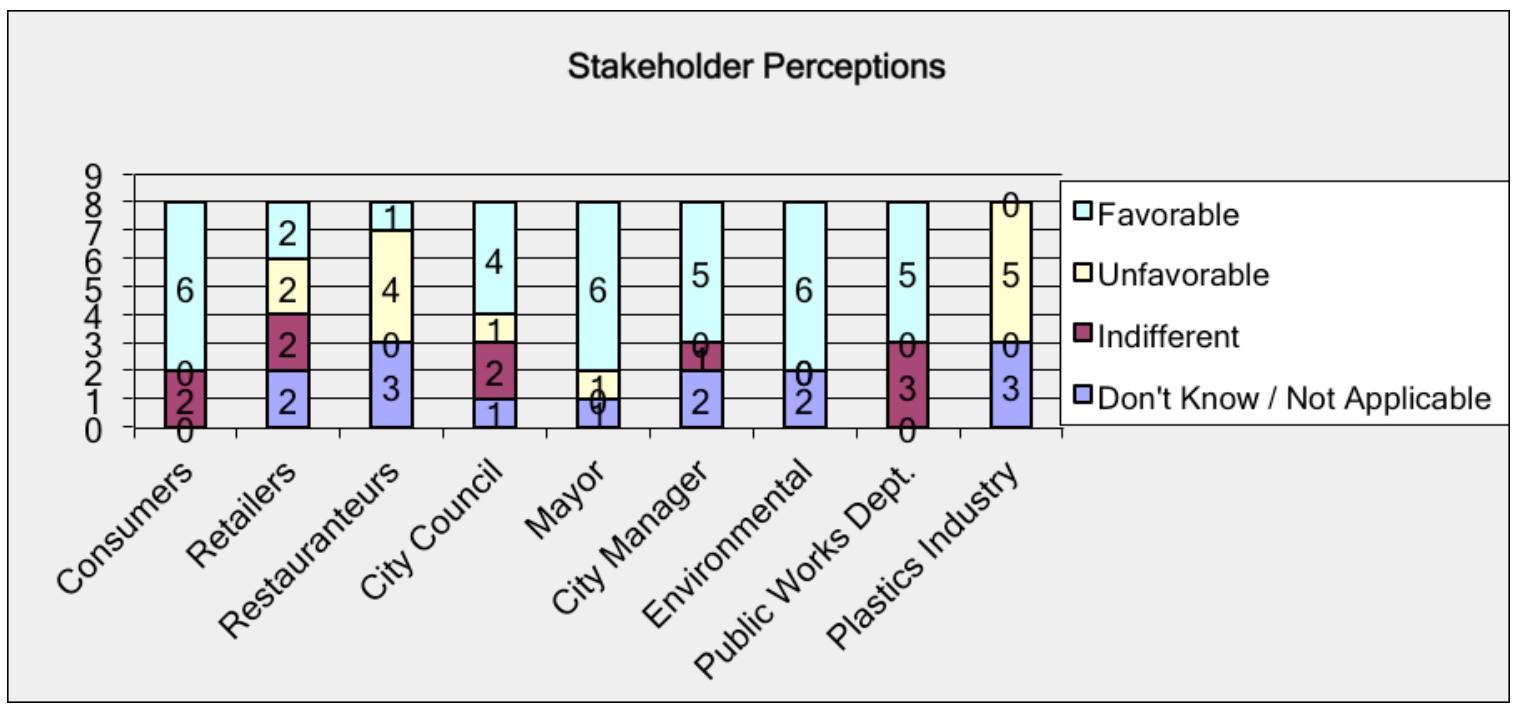




\section{Policy Debate}

Three of the eight respondents (37.5\%) indicated their cities are currently considering adopting a plastic bag / reusable bag policy while five respondents (62.5\%) stated their cities are not doing so. Seven respondents (87.8\%) discussed their communities' concerns adopting a plastic bag / reusable bag policy. Five respondents (71.4\%) said their cities' leaders were concerned about established businesses leaving their communities and others deciding against hanging their shingles within city limits if such a ban became law. These communities and their leaders believe outflow would occur if a plastic bag ban were adopted. Outflow occurs when a city adopts a policy its municipal neighbors have not adopted resulting in negative economic consequences for the adopting city such as businesses relocating and consumers shopping elsewhere to jurisdictions without an ordinance.

Three respondents said lack of staff and funding to implement and enforce policy and monitor compliance caused decision makers to table such policy research. Moreover, a county level administrator said inconsistent application of regulations among cities represented a roadblock to policy development. Finally, three public administrators said their jurisdictions were awaiting the fate of Senate Bill 270, which mandates a statewide ban on single-use plastic bags beginning July 1, 2015. However, a group of plastic bag manufacturers has since placed a referendum on the November 2016 ballot when voters will decide the bill's fate. Until that time SB 270's requirements will not be enforced.

The group of eight respondents was evenly split when asked if their cities' leaders were researching other cities' plastic bag / reusable bag policies. However, all eight respondents said their cities' leaders were not developing their own policies because they were waiting for SB 270 
to take affect. To clarify, all eight respondents completed the survey by February 24, which was the same day that the referendum to SB 270 qualified for the 2016 ballot.

\section{Best Practices}

Six of the eight respondents (75\%) shared best practices related to regulating the use and distribution of single-use plastic bags, recyclable paper bags and reusable bags without an ordinance. The most common referenced practice was stakeholder outreach and education (37.5\%), which was the most frequently listed practice among respondents from adopting jurisdictions. Two respondents said community groups giving away reusable bags to citizens at community events was a beneficial practice. Also, a consumer being able to buy reusable bags in stores proved helpful in affecting consumer norms. One public administrator provided the large retailers' perspective on plastic bag policy in her community by saying they support one bill in the interest of state government applying a consistent policy throughout California.

\section{$\underline{\text { Analysis }}$}

Based on San Francisco's 2009 audit, the average amount of large litter fluctuates slightly each year between 2007 and 2009. This fluctuation is more noticeable between 2007 with 36.3 items per site and 2008 with 30.6 items per site. On the surface, this $16 \%$ drop in large litter infers that San Francisco's Plastic Bag Reduction Ordinance did reduce litter in public spaces. This conclusion is supported by the reduced average items per site despite an increase from 105 observed sites in 2007 to 130 observed sites in 2008. Another key point is that the same original 105 sites observed in 2007 were included in the 2008 audit. With 132 sites surveyed in 2009, the proportion of large litter per site decreased $6.4 \%$ to a mean of 34 items compared to 2007 's baseline average. However, 2009's average jumped 11\% compared to 2008's average. Therefore, 
it can be assumed that slight increases can occur over time, yet be part of an overall downward trend because it can be challenging to connect outcomes with changes in policy.

There appears to be a mix-up in presenting data in San Francisco's 2009 Litter Re-Audit. Specifically, Table 9-The Summary of All Large Observed on page 37 lists 68 items observed as "Plastic Retail Bags" in 2009 while the table entitled, "3.2.3 Bags", on page 42 indicates 23.5 items observed as "Plastic Retail Bags" (San Francisco Streets Litter...2009). Moreover, the amount of "Plastic Bags - Not Retail" is different when comparing the two tables. For example, Table 9 lists the 23.5 items counted as "Plastic Bags - Not Retail" and 68 items counted as "Plastic Retail Bags" (San Francisco Streets Litter...2009). As for the table on page 42 of the Litter Re-Audit, 68 items are listed under "Plastic bags - no brand" and 23.5 items are listed as "Plastic retail bags."

This discrepancy may be attributed to a simple data entry error in Table 9 (San Francisco Streets Litter...2009). Therefore, the researcher assumes that the table entitled, "3.2.3 Bags", reflects the correct data because this table reflects the overall downward trend of less single-use plastic bags following implementation. This trend is supported by the data in the table, "3.2.3 Bags", which shows retail plastic bags as a percentage of large litter dropping from $0.64 \%$ in 2008 to $0.52 \%$ in 2009 . However, the amount of large trash items collected increased $11.4 \%$ from 3,978 items in 2008 to 4,488 items in 2009. This increase in litter can be attributed to two additional survey sites added in 2009. By sheer count, the amount of plastic bags decreased by only two bags from 25.5 in 2008 to 23.5 a year later, which is a $6 \%$ decline. Overall, San Francisco had very few retail plastic bags during the three audits indicating the ordinance's impacts on reducing retail plastic bags. 
San Francisco's litter audit report did not distinguish if site auditors counted litter in creeks, waterways, storm drains or public spaces. The researcher, however, assumes at least that public spaces were audited because, "the consultant had access to... all potential public street locations within the service area of the City of San Francisco" (San Francisco Streets Litter...2009). By 2009, plastic retail bags comprised $12.4 \%$ of the bag sub-category while unbranded plastic bags accounted for 35.9\%, which could be the reason why San Francisco's ordinance applied to all retail and restaurant locations by 2013. Should additional litter audits be performed, the downward trend could have plastic retail bags at zero since they have been eliminated entirely since 2013 .

Therefore, another audit would be beneficial in measuring ordinance impacts today reflecting any potential litter build up in specific locations such as creeks, waterways and storm drains. Bag use trends among consumers would be another helpful indicator of ordinance impact. Representatives from San Francisco's Department of Environment did say that limited staffing and resources make future audits not possible for the time being.

Palo Alto's leaders did not see enough changes following implementation of its Disposable Checkout Bag Ordinance because it only applied to the City's seven grocery stores that were at least 10,000 square feet. As a result, litter still accumulated in public spaces, storm drains and creeks. Also, the proportion of consumers either using reusable bags or no bags plateaued. Eventually, Palo Alto's ordinance began to achieve its legislative intent on a larger scale because all retailers and restaurants were subject to the law to expanded law in 2013. For example, city staff collected $50 \%$ less trash and $34 \%$ less recyclables at its creeks only two months following implementation of its amended ordinance. Within five months of ordinance expansion, zero retail plastic bags were found in city creeks. The expanded ordinance enabled 
Palo Alto to move closer to its trash reduction goal of complying with the San Francisco Water Board's $40 \%$ trash reduction requirement.

In addition, one month prior to the amended ordinance's implementation, $90 \%$ of the contents found in storm drain trash capture devices were leaves and other organic material. These devices "remove trash prior to connection with local receiving waters" to prevent litter from accumulating at storm drains (Weiss e-mail 2014). These trash capture devices helped Palo Alto meet trash reduction requirements for a Municipal Regional Permit from the State Water Resources Control Board (Weiss e-mail 2014). Less trash in city creeks proved the expanded ordinance worked as intended. In addition, Palo Alto's citizens were using less plastic bags at this point in time because the ordinance had been enacted for almost four years by then. Only $4.6 \%$ of all bag observations were plastic bags (Palo Alto 2014d).

Despite more consumers using reusable bags and carrying items without bags following ordinance adoption 2009, recyclable paper bag use represented a majority of store exit observations between 51.8\% and 53.7\% from 2010 to 2012. All three bag types, except plastic, experienced mostly-upward trends between 2009 and 2013 since plastic bags were eliminated. Once the expanded ordinance took effect, observations of paper bags began dropping in 2013 before reaching $23.9 \%$ by 2014 . As a result, more customers either elected to purchase reusable bags or decline bags for small, portable items. By 2014, consumers using no bags comprised $41 \%$ of observations while reusable bags reached $35 \%$ and paper bags represented $24 \%$ (Palo Alto 2014d). These numbers prove norms among consumers have changed because consumers are using less paper bags. Furthermore, customers would rather pay fees for a bag they can use at least 125 times compared to a bag they can use usually once. Also, consumers are applying 
environmental awareness by reusing what resources they have instead of discarding them, thus reducing the overall trash load.

After steady increases in the amount of plastic bags in 2009 and 2010, City of San Jose staff observed a sharp decline of 59\% in retail plastic bags found in neighborhoods by 2012 (San Jose 2013d). This proportion is based on a varying number of surveyed sites in 2009, 2010 and 2012. City staff counted 387 (4.9\% of litter) retail plastic bags from 7,917 garbage items at 48 sites in 2009 (San Jose 2013d). A year later, staff counted 409 retail plastic bags (5.3\% of litter) from 7,784 litter items at 59 sites (San Jose 2013d). With an increased sample size of sites, more plastic bags were collected despite the overall trash count dropping by 1.7\% (San Jose 2013d). Following ordinance implementation in 2012, staff counted 3,679 pieces at 31 sites. Seventy-six items were retail plastic bags (2.1\% of litter) (San Jose 2013d). In retrospect, surveying the same sites and same amount of sites during each survey year may have produced more accurate results in neighborhood litter trends. Then again, either city staff may felt the smaller sample size in 2012 was sufficient enough or perhaps staff members were prevented from surveying more areas. Also, the ordinance's impacts may have made a quick impact on reducing litter in neighborhoods. See Table 10 on page 63 for more information. A consistent sample size during each survey year would provide more reliable results because the test group would (observed sites) not have been affected.

City staff surveyed 69 catch basins in April 2012 resulting in a mean of 0.13 bags per site equaling an $89 \%$ decrease compared to pre-ordinance data (San Jose 2013d). This survey was the only post ordinance implementation survey from the researcher's available records. Without any subsequent surveys conducted to compare with the lone post implementation results, no trend can be identified. However, since the average amount of 0.13 bags was so small, staff may have 
believed the BYOB ordinance was effective. Also, budget restrictions may have prevented further surveys.

Prior to implementation, five catch basin surveys occurred between 2008 and 2012 with the mean amount of retail plastic bags declining each time from 1.8 bags to 0.32 bags (San Jose 2013d). Like the neighborhood litter surveys, varying amounts of storm drains were inspected ranging from 31 drains to 65 drains. Again, more accurate trends may have been presented if the amount of storm drains remained consistent. However, as the sample sizes increased, the average amount of bags in catch basins decreased. See Table 14 on page 68 for more details. It is interesting to see a declining trend in plastic bag litter prior to implementation because the

City creeks represented a major source of plastic bag litter before ordinance implementation in 2012. Staff collected 670 bags (12.2\% of total) at five sites in 2010 and 1,367 bags ( $8.2 \%$ of total) in 2011 at ten sites. One possible reason for the increased amount of bags besides the larger sample size is that wind and water carry the light plastic bags to these locations. By virtue of this activity, retail plastic bags accumulated in creeks. Perhaps members of the homeless community contributed to plastic bag litter appearing in creeks since homeless have congregated in these areas in the past. Moreover, since single use plastic bags were free and easily obtained by being in the litter stream already. By comparison, ten sites were surveyed post implementation in 2012 and 2013. The amount of bags decreased by 63\% from 513 bags in 2012 to 190 bags in 2013 (San Jose 2013d). These results indicate the effects of the BYOB ordinance since consumers were using reusable bags, paper bags or no bag in the absence of the once ubiquitous plastic bags. Since retailers could not distribute plastic bags, less plastic bags were in the litter stream. These results reflect the legislative intent of San Jose's ordinance by reducing litter in creeks and rivers. 
Store exit observation data reflect a sharp decline in the average amount of bags per customer before and after implementation in 2012. The average amount of bags dropped $72 \%$ from three bags per customer to 0.85 bags per customer (San Jose 2013d). The downward trend began in 2010 when customers at ten stores averaged 5.6 bags during a winter survey and just 1.2 bags at 11 stores by the summer (San Jose 2013d). Two years later, customers averaged 0.85 bags during two surveys combined at seven stores (San Jose 2013d). The decreased average of bags can be attributed to more consumers using fewer reusable bags compared to paper and plastic bags because these receptacles can support 22 pounds of weight. Also, more consumers are carrying items on their person instead of using bags to carry these items. See Table 16 on page 71 for details.

For communities with storm drain permits, meeting the San Francisco Water Board's $40 \%$ trash reduction mandate proved challenging for some cities and manageable for others. Cities with few resources and staff found it difficult to inspect and clean streets and trash capture devices. This effect resulted from single-use plastic bags accumulating most frequently in creeks and public spaces such as sidewalks and streets regardless if the city had adopted a plastic bag policy or not. Wind and water are key culprits in transporting single-use plastic bags that are lightweight and float in the air and on water. Trash in one city can land in a neighboring community due to weather conditions. Trash can also travel across municipal borders because cities share arterial streets and routes that connect cites and are populated by retailers, restaurants and public space. Another possible contributing factor is homeless community members who congregate at creeks and rivers and dispose of their trash in these locations resulting in litter buildup in creeks and streams. 
However, after plastic bag bans and reusable bag ordinances became law, reducing single-use plastic bag litter in creeks, streams, rivers and storm drains was mostly successful. Therefore, most bag ordinances can achieve their goals with well-funded staff and stakeholders who embrace these types of policies. Lastly, cities subject to the $40 \%$ trash reduction target were also motivated to reduce litter.

In non-adopting communities, mayors, environmental departments and consumers welcomed the idea of a plastic bag policy. However, city council members held a mixed view of a plastic bag ban while restaurateurs and retailers did not hold such a favorable perception of this type of policy. Perhaps businesses leaving or deciding not to establish themselves in a particular jurisdiction con tribute to negative perception of plastic bag ordinances, which was the case in smaller cities.

While plastic bag policies mostly received strong support from local government, perceived support among consumers, retailers and restaurateurs was significantly less. Based on Bay Area municipal and county administrators' perceptions, half of consumers favored such plastic bag policies while just over $41 \%$ of retailers approved. Only $25 \%$ of restaurateurs seemed to agree with local bag policies. Consumers held a mixed view because people are creatures of habit who do not always embrace changes. As for retail stores and restaurants, these businesses may have to adjust to various municipal laws if they have locations in various cities in California. These stakeholders prefer a single law to make compliance feasible for all their business locations. Senate Bill 270, which is up for a referendum vote in 2016, would have applied to California cities without an adopted plastic bag policy as of September 2014. Nonadopting cities were anticipating SB 270 being implemented in July 2015, which is one reason these communities delayed adoption. For now, mostly homogenous local laws dictate bag policy. 
Finally, behavior change among consumers, retailers and restaurateurs happens on a wide scale when they are forced to change their habits or adopt new norms as these laws have intended.

A uniform policy as mentioned previously is what made the policy adopting process easier for some communities. County ordinances attracted cities because implementation, outreach, compliance were handled at the county level. Ultimately, costs of enforcing the ordinance rested with the counties. A consistent policy across local borders with effective outreach and education made compliance easier for businesses and consumers. Both adopting and non-adopting cities cited outreach to and education of stakeholders as the most effective best practice related to the adoption process. This approach benefitted late adopters because policy makers and decision makers observed how bag policies were adopted and implemented in other communities. Late adopters also learned from challenges early adopters faced, in particular lawsuits brought by representatives of the plastics industry.

Cities and counties facing the lawsuits and the threat of lawsuits from the plastics industry represented a significant challenge among adopting cities. For instance, bag policies only existed at the local level so no higher authority, such as state government, regulated this policy area. As a result, plastic bag polices were being tested in the laboratories of democracy that are America's cities; and thus, ripe for criticism. Lastly, the American plastics industry challenged local bag policies because it was well organized and well funded. By 2010, however, court decisions ruled that plaintiffs who sued cities and counties over bag policies must also cover costs related to these lawsuits, which made litigants think twice before going forward. This shift, along with court decisions supporting local bag policies, encouraged other local governments to pursue their own bag policies leading to many late adopters after 2010 . 


\section{Conclusion}

Although significant, policy adoption and implementation are just parts of the policy learning process in the laboratories of democracy that are America's cities. Policy is constantly changing to better address needs and achieve legislative intent. Changes work when laws require compliance such as banning plastic bags and offering reusable bags. However, Stakeholders are more likely to embrace changes when they are given a choice such as consumers choosing to purchase a bag or not. Later adopters have the benefit of observing how early adopters adjust to outcomes and stakeholder reaction to provide guidance in the adoption and implementation process. According to Californians Against Waste, 139 cities and counties have adopted 110 plastic bag ordinances (2014). Should SB 270 become law in 2016, trash reduction targets will be more attainable and the negative environmental impact will be reduced because every municipality will be covered by plastic bag policy. SB 270 will survive the referendum if California voters vote it down. 


\section{Appendix A: Retail Bag Ordinance Survey (Adopter)}

1. What is your city or town's current population? Please enter your response in the space below.

\begin{tabular}{|c|c|c|}
\hline Answer Options & Response Count & \\
\hline & 16 & \\
\hline Answered question & & 16 \\
\hline Skipped question & & 0 \\
\hline Number & Response Text & \\
\hline 1 & & 490,000 \\
\hline 2 & & 100,000 \\
\hline 3 & & 40,000 \\
\hline 4 & & 76,815 \\
\hline 5 & $850,000,1.2+$ million during business day & \\
\hline 6 & & 40,584 \\
\hline 7 & & 5,155 \\
\hline 8 & & 120,245 \\
\hline 9 & & 74,000 \\
\hline 10 & & 28,931 \\
\hline 11 & & 75,000 \\
\hline 12 & & 1,458 \\
\hline 13 & & 76,000 \\
\hline 14 & & 800,000 \\
\hline 15 & & 30,000 \\
\hline 16 & & 258,000 \\
\hline
\end{tabular}




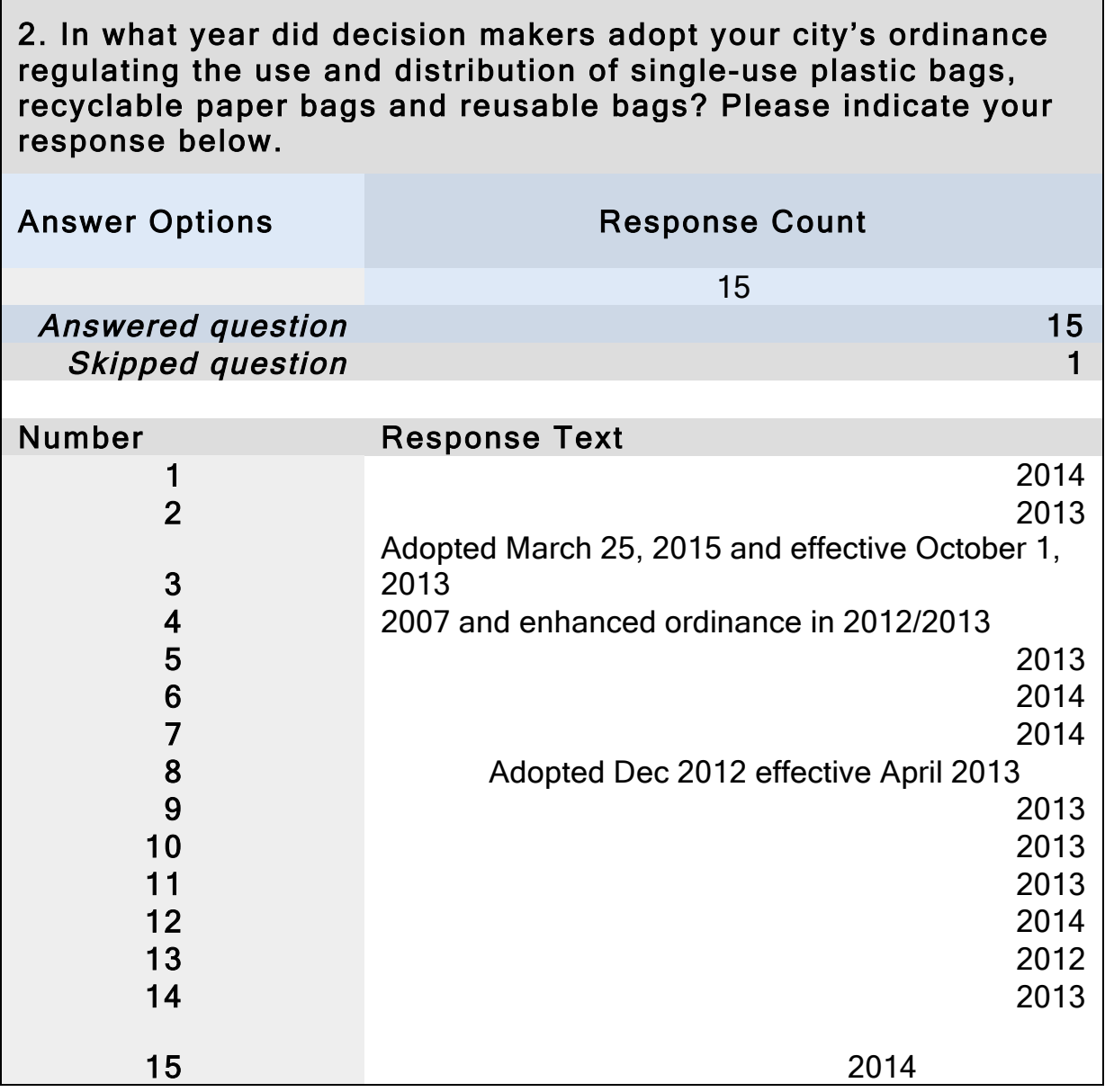


3. Is your city's ordinance based on another city's ordinance?

\begin{tabular}{|c|c|c|}
\hline Answer Options & $\begin{array}{c}\text { Response } \\
\text { Percent }\end{array}$ & Response Count \\
\hline Yes & $75.0 \%$ & 12 \\
\hline No & $25.0 \%$ & 4 \\
\hline Don't Know / Not Applicable & $0.0 \%$ & 0 \\
\hline
\end{tabular}

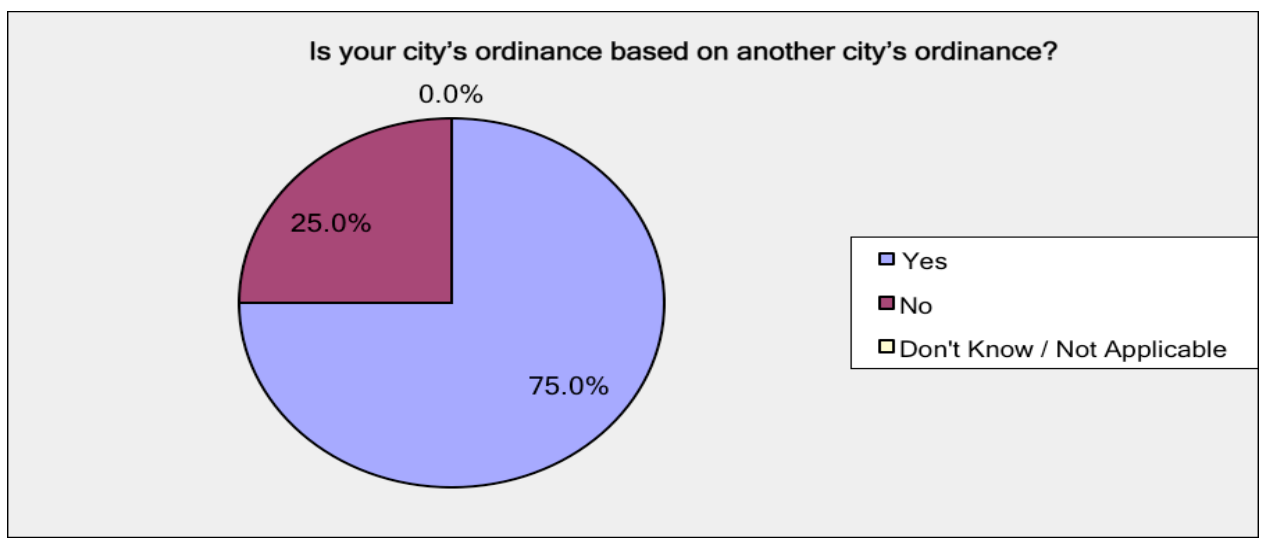

4. Does your city have a storm drain permit with the San Francisco Bay Regional Water Quality Control Board? If you answer other than yes, please skip to question five.

Answer Options

Yes

No

Don't Know / Applicable
Response

Percent

$62.5 \%$

$6.3 \%$

$31.3 \%$

Answered question

Skipped question
Response Count

10

1

5 


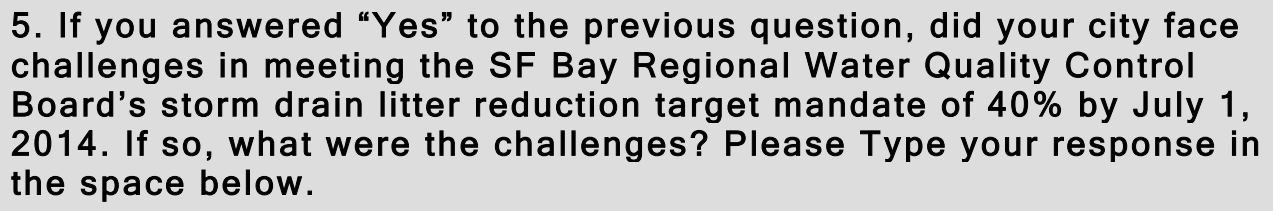

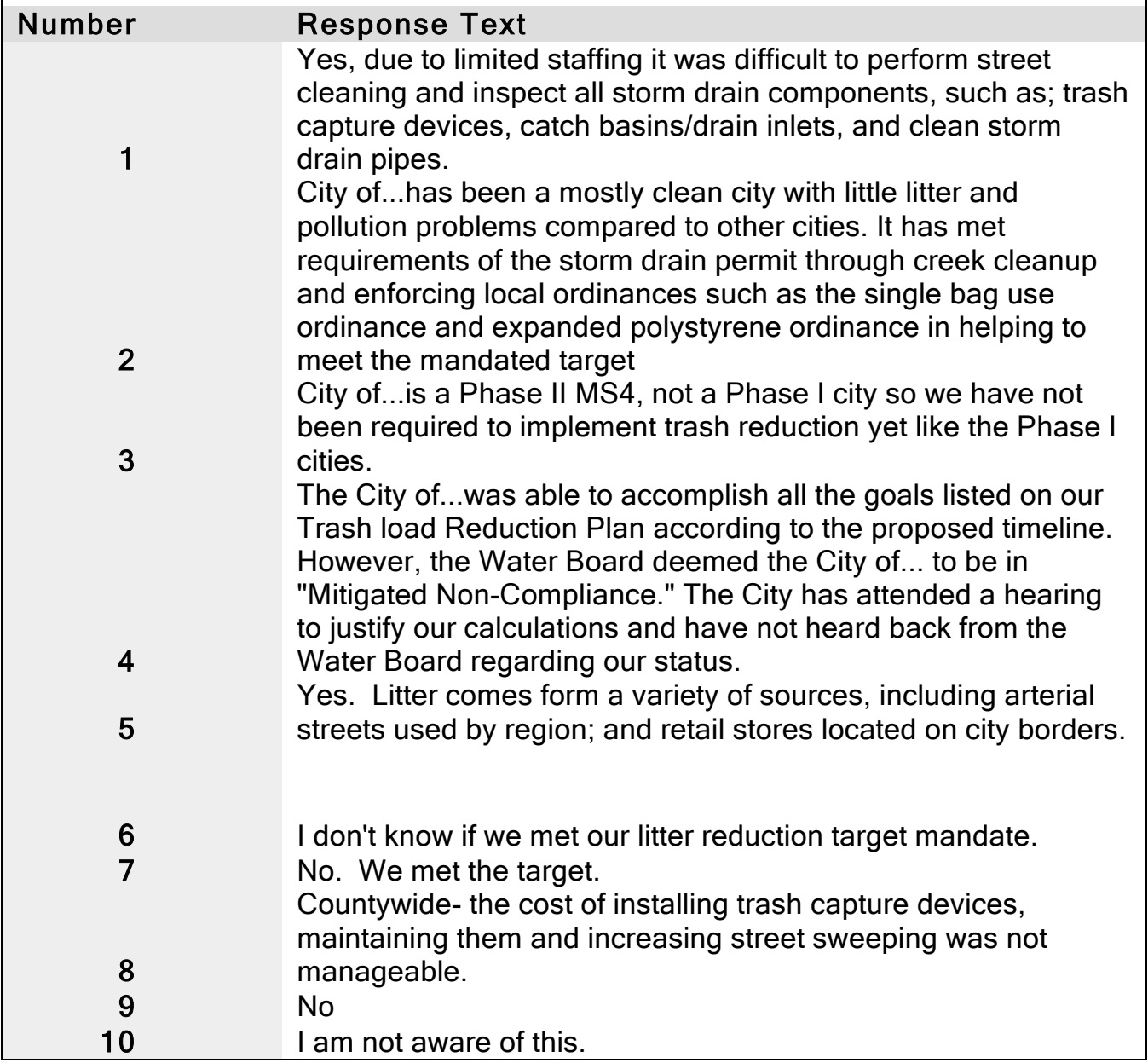


6. Litter reduction in the form of single-use plastic bags in creeks, rivers, streams and waterways. Streams are defined as narrow rivers not used for travel. Waterways are defined as canals, rivers or other routes used for travel. Circle one of the following choices:

Answer Options

Response Percent Response Count

Not Successful

Somewhat Successful

Successful

Very Successful

$\begin{array}{cc}0.0 \% & 0 \\ 16.7 \% & 2 \\ 75.0 \% & 9 \\ 8.3 \% & 1\end{array}$

Answered question

Skipped question

Litter reduction of single-use palstic bags

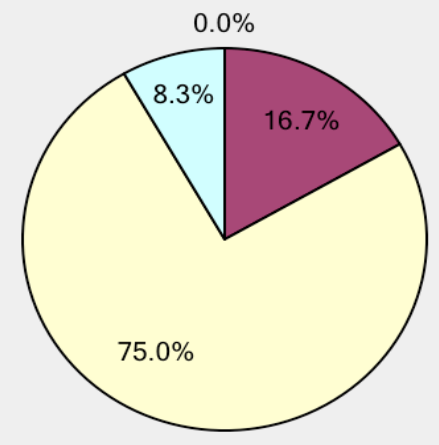

$\square$ Not Successful

口Somewhat Successful

口Successful

$\square$ Very Successful 


\begin{tabular}{|l|cc|}
\hline \multicolumn{3}{|l|}{ 7. Litter reduction in the form of single-use plastic bags } \\
in storm drains. Circle one of the following choices: \\
Answer Options & $\begin{array}{c}\text { Response } \\
\text { Percent }\end{array}$ & $\begin{array}{c}\text { Response } \\
\text { Count }\end{array}$ \\
Not Successful & $9.1 \%$ & 1 \\
Somewhat Successful & $9.1 \%$ & 1 \\
Successful & $72.7 \%$ & 8 \\
Very Successful & $9.1 \%$ & 1 \\
& Answered question & 11 \\
Skipped question & 5 \\
\hline
\end{tabular}

Litter reduction in the form of single-use plastic bags in storm drains. Circle one of the following choices:

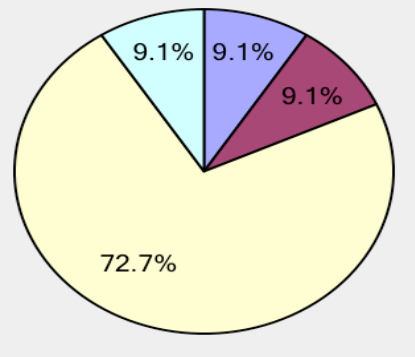

8. Reduction in litter collection and abatement costs since your city implemented its ordinance.

Answer Options

Not Successful

Somewhat Successful

Successful

Very Successful
Response Percent

$22.2 \%$

$22.2 \%$

$55.6 \%$

$0.0 \%$
Response Count

\section{2}

2

5

0

\section{Answered question}

Skipped question

Reduction in litter collection and abatement costs since your city implemented its ordinance.

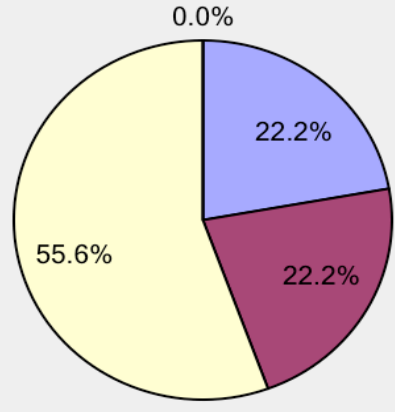

$\square$ Not Successful

口Somewhat Successful

口Successful

$\square$ Very Successful 


\begin{tabular}{|c|c|c|c|c|}
\hline $\begin{array}{l}\text { 9. Does litte } \\
\text { the following } \\
\text { Streams are } \\
\text { Waterways } \\
\text { travel. }\end{array}$ & $\begin{array}{l}\text { forn } \\
\text { s in } \\
\text { d as } \\
\text { ined }\end{array}$ & $\begin{array}{l}\text { e-us } \\
\text { Sel } \\
\text { vers } \\
\text {, riv }\end{array}$ & $\begin{array}{l}\text { stic bags acc } \\
\text { Il choices th } \\
\text { used for trav } \\
\text { r other route }\end{array}$ & $\begin{array}{l}\text { mulate in } \\
\text { apply. } \\
\text { used for }\end{array}$ \\
\hline $\begin{array}{l}\text { Answer } \\
\text { Options }\end{array}$ & Yes & No & $\begin{array}{c}\text { Don't Know } \\
\text { / Not } \\
\text { Applicable }\end{array}$ & $\begin{array}{c}\text { Response } \\
\text { Count }\end{array}$ \\
\hline Creeks & 8 & 2 & 3 & 13 \\
\hline Streams & 6 & 2 & 5 & 13 \\
\hline Waterways & 6 & 1 & 6 & 13 \\
\hline Public Space & 9 & 2 & 2 & 13 \\
\hline & & & $\begin{array}{l}\text { red question } \\
\text { ped question }\end{array}$ & $\begin{array}{r}13 \\
3\end{array}$ \\
\hline
\end{tabular}

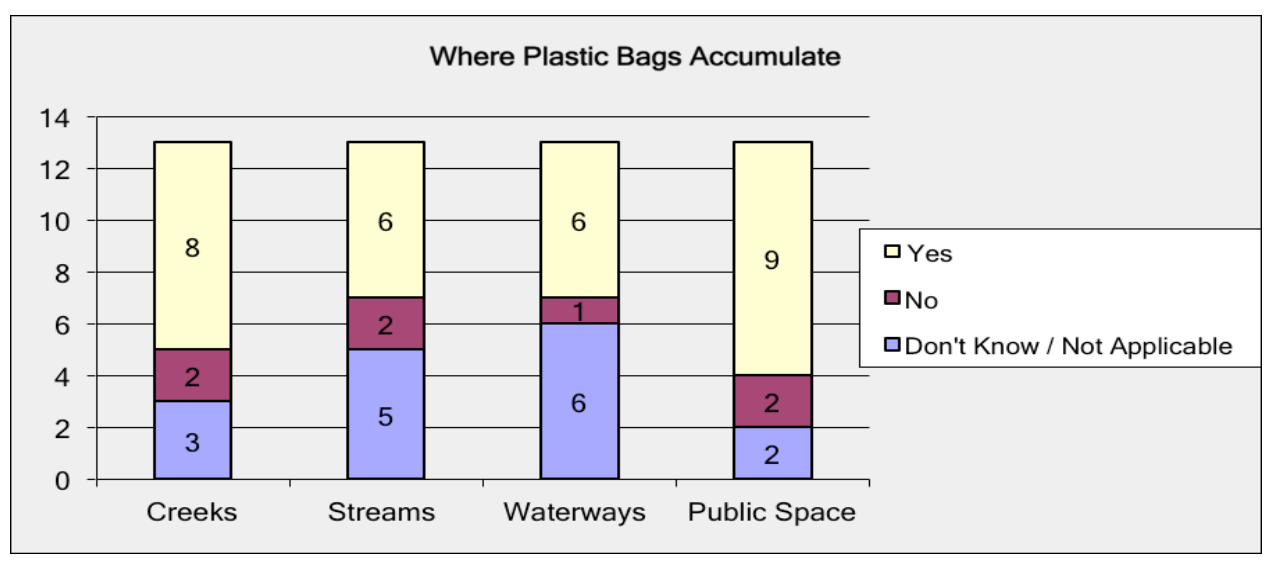

10. Below is a list of groups, agencies and organizations that are most likely affected by a reusable bag ordinance and or plastic bag ordinance in your city. Based on your perceptions and experiences do you feel each has a favorable attitude toward the ordinance, an unfavorable attitude, an indifferent attitude, or do you not have enough information to make this assessment?

\section{Answer}

Options

Favorable Unfavorable Indifferent

\section{Don't}

\section{Consumers}

Retailers

Restaurateurs

City Council

Mayor

City Manager

Environmental

Department

Public Works

Plastics

Industry

$\begin{array}{cc}6 & 0 \\ 5 & 2 \\ 3 & 1 \\ 12 & 0 \\ 12 & 0 \\ 10 & 1 \\ 9 & 0 \\ 9 & 0 \\ 0 & 9\end{array}$

4
4
3
0
0
1
0
2
2

Know / Not Applicable

Response Count

$\begin{array}{lll}2 & 12 & \\ 1 & 12 & \\ 5 & 12 & \\ 0 & 12 & \\ 0 & 12 & \\ 0 & 12 & \\ 3 & 12 & \\ 1 & 12 & \\ 1 & 12 & \\ \text { question } & & \mathbf{1 2} \\ \text { question } & & \mathbf{4}\end{array}$




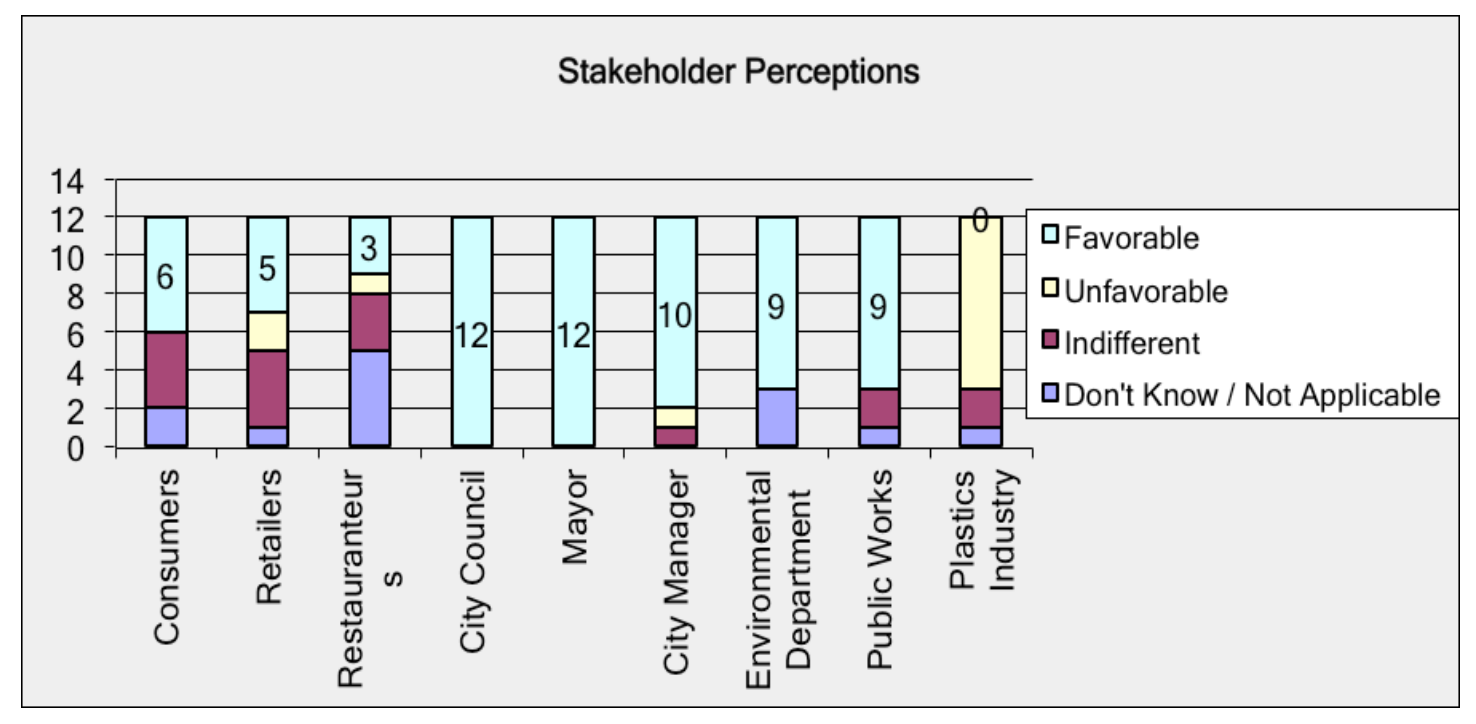

11. Often in the policymaking process ideas and beliefs about what behavior is appropriate to communities at-large can often shape decision-making. Based on your experience, do citizens in your city believe single-use plastic bags are an environmental danger and that reusable bags are the best substitute available?

\begin{tabular}{|c|c|c|}
\hline Answer Options & $\begin{array}{c}\text { Response } \\
\text { Percent }\end{array}$ & $\begin{array}{c}\text { Response } \\
\text { Count }\end{array}$ \\
\hline Yes & $76.9 \%$ & 10 \\
\hline No & $0.0 \%$ & 0 \\
\hline Don't Know / Too Early to Ascertain & $23.1 \%$ & 3 \\
\hline$A n$ & red questior & 13 \\
\hline
\end{tabular}

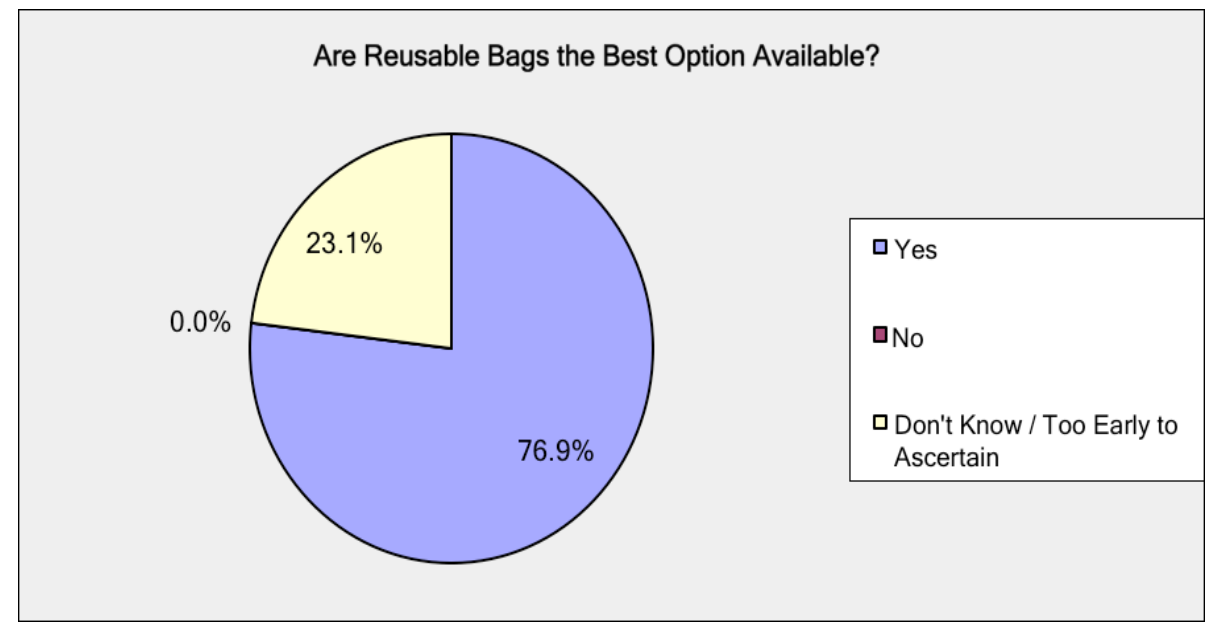


13. Often in the public policy making process we can make distinctions between early adopters of a policy and "late" adopters. For the purpose of this project we can divide cities between "early adopters," those cities adopting an ordinance between 2007 and 2010, and "later adopters," cities adopting an ordinance after 2010 . What challenges, if any, did your city's policy makers and decision makers face as an early or late adopting city?

Answer Options

Response Count

12

Answered question

Skipped question

\begin{tabular}{|c|c|}
\hline Number & Response Text \\
\hline 1 & Getting all councils/Boards to agree on consistent ordinance language. \\
\hline 2 & $\begin{array}{l}\text { Reassuring stakeholders that the County would fund outreach, inspection, and } \\
\text { compliance; that enforcement wouldn't be punitive; that the community would approve } \\
\text { (there wouldn't be a huge backlash); and that ultimately, the businesses would be okay } \\
\text { with the ordinance. }\end{array}$ \\
\hline 3 & Bag Lobbyist and the threat of lawsuits \\
\hline 4 & $\begin{array}{l}\text { City of...was late adopter due to the fact that cities that adopted before } 2010 \text { were all } \\
\text { being sued by the plastic bags manufacturer, which made it very costly for cities. After } \\
2010 \text { however, Courts have decided that the party that is suing the city has to cover the } \\
\text { costs as well. That was when... decided to take action in adopting the ordinance }\end{array}$ \\
\hline 5 & $\begin{array}{l}\text { Late-adopter: lack of support from the City Manager, some Council members and the } \\
\text { Chamber of commerce. }\end{array}$ \\
\hline 6 & $\begin{array}{l}\text { Being a "late adopter" was actually a benefit, since we had a few court cases that } \\
\text { provided direction on the type of environmental review we had to do, what other cities } \\
\text { were doing, etc. }\end{array}$ \\
\hline 7 & $\begin{array}{l}\text { Late adopter. Little challenges because city ordinance was part of a regional effort in two } \\
\text { counties. Adopting regionally helped to provide a level playing field for retailers and less } \\
\text { confusion for customers. }\end{array}$ \\
\hline 8 & $\begin{array}{l}\text { We had noticed issues regarding policy changes (transparency in gov't) play a role in } \\
\text { adopting the reusable bag ordinance. After getting through those bumps, we have been } \\
\text { successful with the ordinance. }\end{array}$ \\
\hline 9 & As a late adopting city, we had people wondering why we hadn't done it yet. \\
\hline 10 & $\begin{array}{l}\text { None. We adopted the county ordinance. They provide enforcement, and the adoption } \\
\text { process went smoothly. }\end{array}$ \\
\hline 11 & $\begin{array}{l}\text { As a late adopter, the challenge was to find real data in terms of environmental benefits } \\
\text { and economic effects of an ordinance. }\end{array}$ \\
\hline 12 & $\begin{array}{l}\text { The County faced a lawsuit by being an early adopter. Another city adopted a policy by } \\
\text { voter initiative and did not. The rest of the cities and towns were later adopters and } \\
\text { benefited from an EIR being drafted. }\end{array}$ \\
\hline
\end{tabular}


14. Has you city's decision makers adopted an amendment to its retail bag policy? If you answer NO to this question please skip questions 14 and 15.

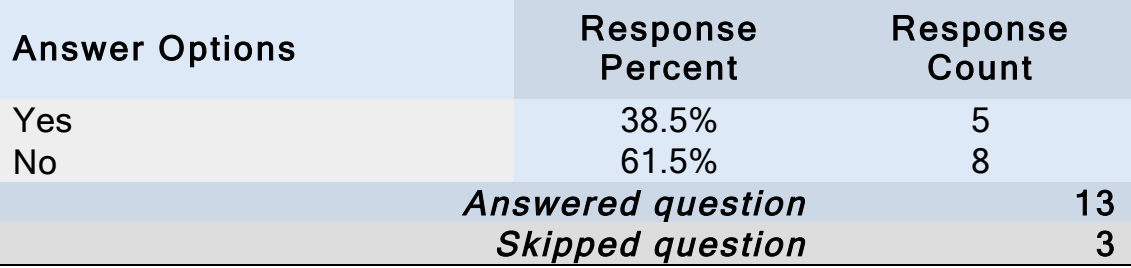

Has your city's decision makers adopted an amendment to its retail bag policy?
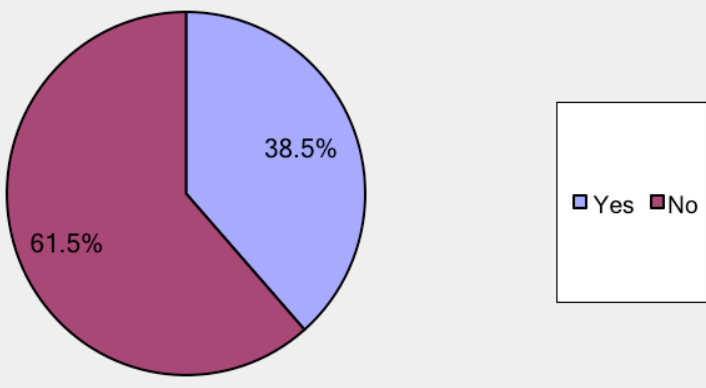
15. In your opinion, what is the most significant amendment to your city's ordinance since its implementation, if applicable? Please explain.

Answer Options

Response Count

5

Answered question 5

Skipped question

\begin{tabular}{|c|c|}
\hline Number & Response Text \\
\hline 1 & Just clarified a small point \\
\hline 2 & $\begin{array}{l}\text { The ordinance would have become effective } 30 \text { days from approval, but the City amended } \\
\text { that and decided to make the actual implementation and enforcement effective on Oct. } 1 \text {, } \\
2013 \text {. }\end{array}$ \\
\hline 3 & $\begin{array}{l}\text { Adding a } 10 \text { cent charge applicable to all retail in } 2012 \text { and applicable to food service } \\
\text { vendors in } 2013\end{array}$ \\
\hline 4 & $\begin{array}{l}\text { The City amended the single bag use ordinance this past November regarding the } \\
\text { increase in bag fees. It followed the footsteps of other surrounding cities to not raise the } \\
\text { fee to } 25 \text { cents per bag and will remain at the current } 10 \text { cents after seeing the success } \\
\text { and compliance of the ordinance. }\end{array}$ \\
\hline 5 & $\begin{array}{l}\text { The only amendment was not increasing the fee from } 10 \text { cents to } 25 \text { cents as } \\
\text { automatically scheduled. The } 10 \text {-cent fee was sufficient to change customer's behavior. }\end{array}$ \\
\hline
\end{tabular}


16. If your city has amended its retail bag policy, rate your city's level of success regarding this amendment by circling one of the choices listed below. Success is defined as full ordinance compliance by retailers, and changing norms among consumers to where they use reusable bags when carrying out purchased retail items.

Answer Options

Response Response

Not Successful

Percent

Somewhat Successful

$0.0 \%$

$0.0 \%$

$37.5 \%$

Successful

$25.0 \%$

$0.0 \%$

Too Early to Ascertain

$37.5 \%$

Count

Not Applicable

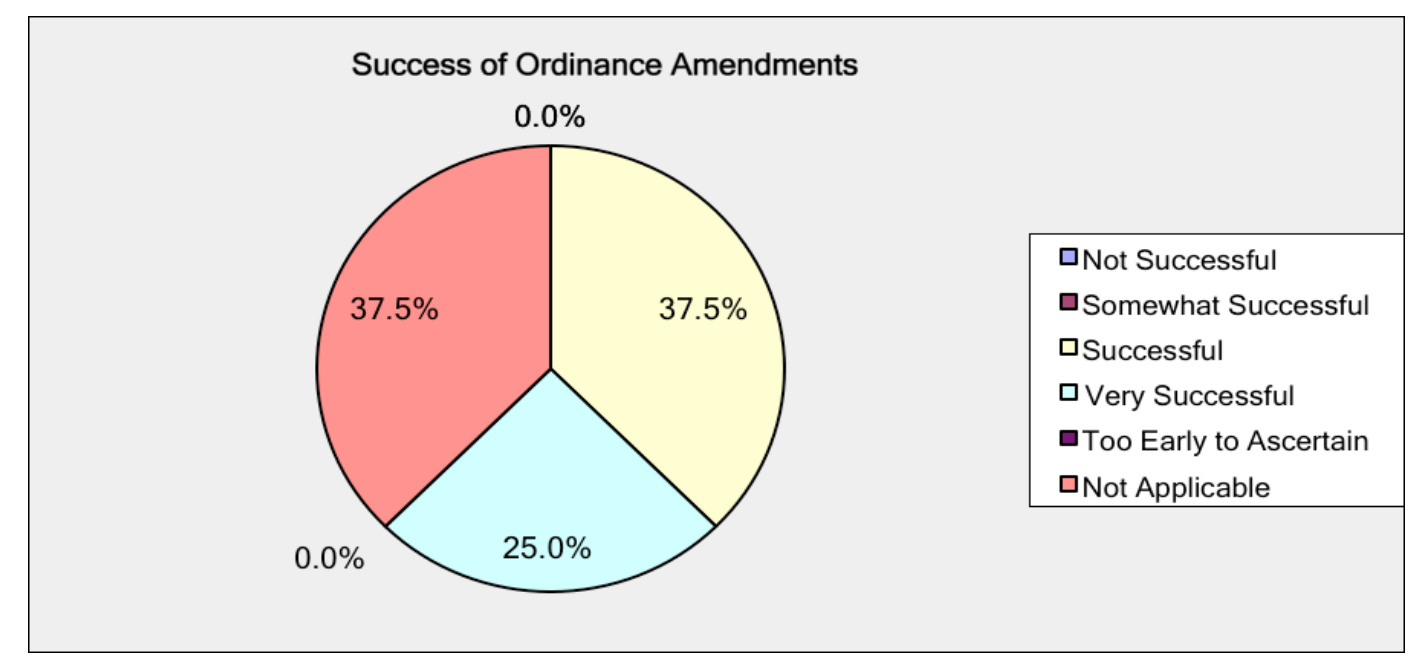


17. Briefly explain what your city learned or has learned from other municipalities' experiences in adopting and implementing their ordinances when crafting its current ordinance?

Answer Options

Response Count

12

Answered question Skipped question

\begin{tabular}{|c|c|}
\hline Number & Response Text \\
\hline 1 & Enforcement has no been a major issue. \\
\hline 2 & $\begin{array}{l}\text { Quite a bit. We modeled our ordinance and public education efforts after two other South } \\
\text { Bay cities }\end{array}$ \\
\hline 3 & $\begin{array}{l}\text { Achieving critical mass in a region is better than going it alone. Knowing where the money } \\
\text { is coming from for outreach, training, inspection, and compliance is important for } \\
\text { stakeholder buy-in. Reassuring the public that enforcement isn't punitive and showing the } \\
\text { public how compliance benefits the community are also both very important. }\end{array}$ \\
\hline 4 & $\begin{array}{l}\text { That a charge at checkout across the board is and extra message that gets passed to } \\
\text { consumers that they have a choice in reducing their environmental impact by reducing the } \\
\text { amount of bags that we take and receive }\end{array}$ \\
\hline 5 & $\begin{array}{l}\text { It has shown to be successful in most cities with the ordinance being consistent } \\
\text { throughout most cities to make it easy to implement }\end{array}$ \\
\hline 6 & $\begin{array}{l}\text { We learned that we needed to consider bag providers that aren't normally thought of as } \\
\text { retailers, such as restaurants who have a large amount of take-out orders }\end{array}$ \\
\hline 7 & $\begin{array}{l}\text { It is better to adopt an ordinance that is similar to other nearby cities. This does NOT } \\
\text { mean watered down. }\end{array}$ \\
\hline 8 & $\begin{array}{l}\text { That we needed the waste management authority backing in order to be successful. } \\
\text { Another city went through lawsuits with their bag ban, and we did not want the same } \\
\text { hassle. }\end{array}$ \\
\hline 9 & $\begin{array}{l}\text { We learned that there would be legal battles if we did not make certain exemptions for } \\
\text { restaurants (prepared food), retail, SNAP and WIC customers, etc. }\end{array}$ \\
\hline 10 & $\begin{array}{l}\text { Nothing - Since the County manages enforcement, we have not needed to be involved in } \\
\text { implementation, and adoption was easy. }\end{array}$ \\
\hline 11 & $\begin{array}{l}\text { Understanding that we needed to do this Countywide as opposed to unincorporated parts } \\
\text { of the County and wait for cities to sign on. }\end{array}$ \\
\hline 12 & IR was very helpful to the citie \\
\hline
\end{tabular}


18. How significant have neighboring cities with bag policies, by virtue of their proximity to your city, had on your city's decision to adopt a bag policy related to single-use plastic bags, reusable bags and recycled paper bags?

Answer Options

Not Significant

Somewhat Significant

Significant

Very Significant

Don't Know / Not Applicable
Response

Percent

$7.7 \%$

$15.4 \%$

$30.8 \%$

$46.2 \%$

$0.0 \%$

Answered question

Skipped question
Response

Count

\section{1}

2

4

6

0

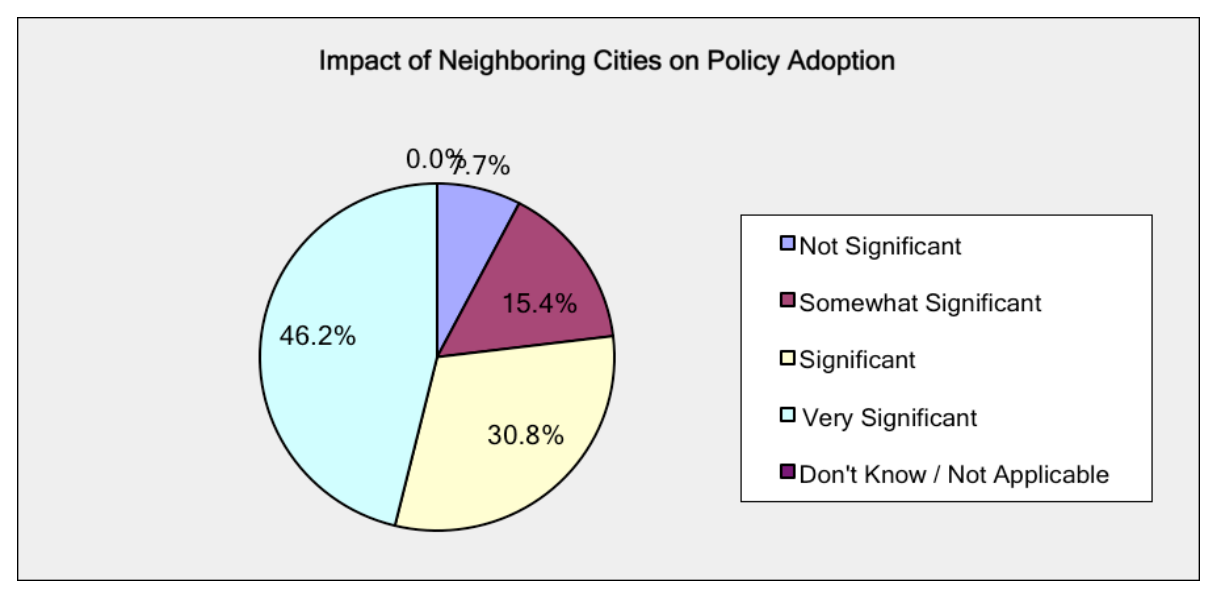




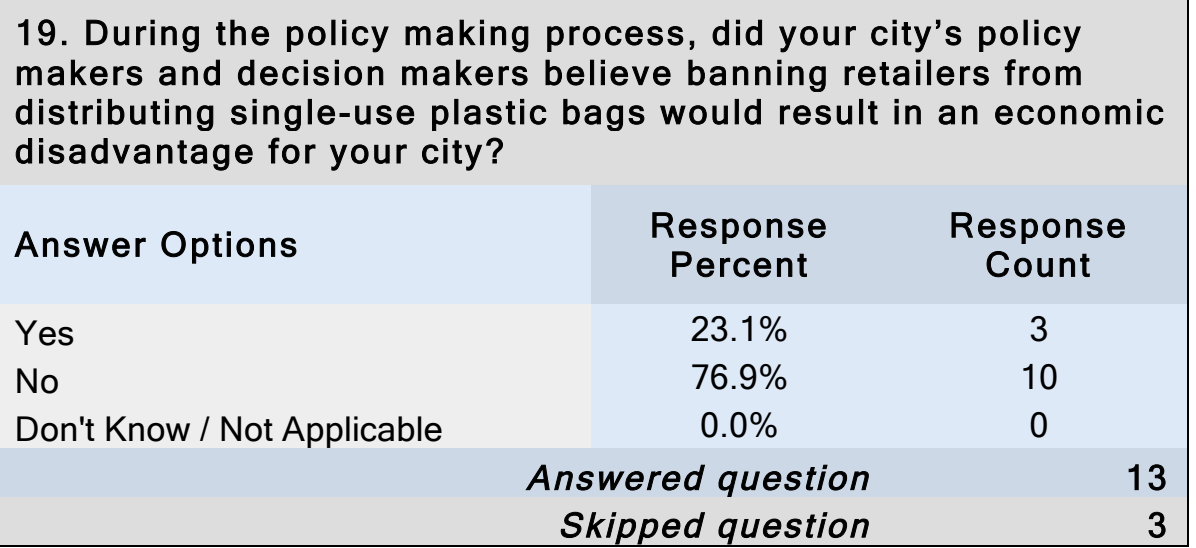

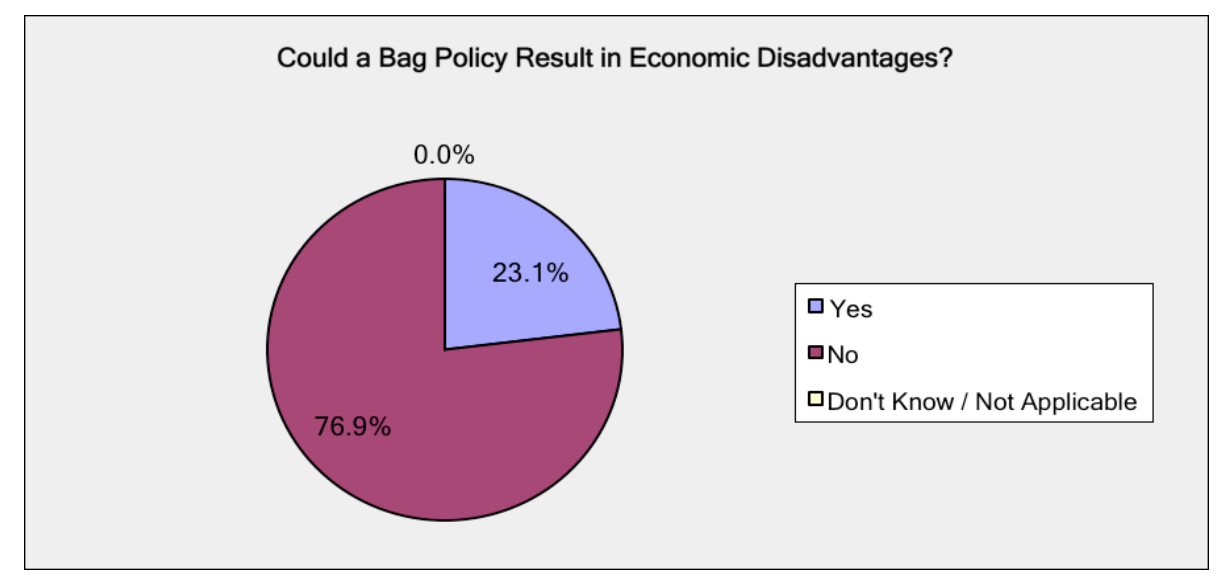


20. If you answered yes to the previous question, would you say your city experienced negative economic consequences as a result of adopting its ordinance? An example of a negative economic consequence would be residents spending their money at retailers in neighboring cities without bag policies to avoid bag fees.

Answer Options

Yes

No

Don't Know / Not Applicable

\section{Response Response Percent Count}

$0.0 \%$

$40.0 \%$

$60.0 \%$

0

2

3

Dld Adopting an Ordinance Result in Negative Economic Consequences?

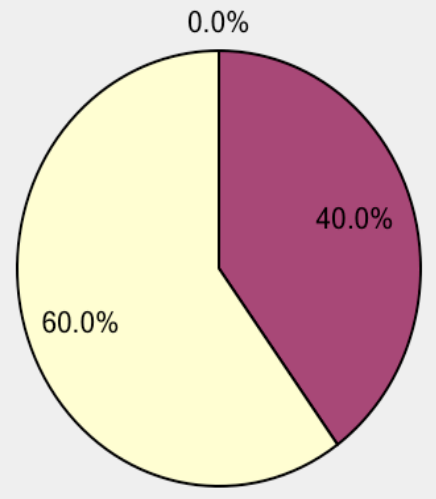

口Yes

$\square$ No

口Don't Know / Not Applicable 
21. Some plastic bag reduction ordinances include provisions that exempt recipients of federally funded state assistance programs like Women Infants and Children (WIC) and Supplemental Nutrition Assistance Program (SNAP) from paying the minimum fee for purchasing recycled bags and reusable plastic bags. However, other ordinances have phased out or intend to phase out these exemptions. Are WIC and SNAP recipients in your city now subject to the minimum fee for purchasing recycled paper bags and reusable bags?

Answer Options

Response Response

Yes

Percent

Count

No

$23.1 \%$

$61.5 \%$

Don't Know / Not Applicable

$15.4 \%$

\section{Exemptions for WIC \& SNAP Recipients?}

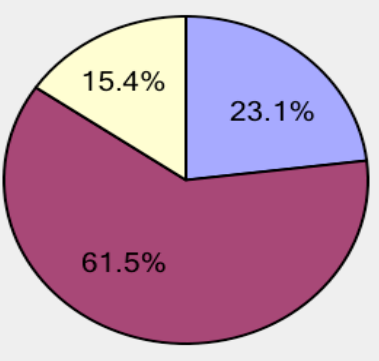

口Yes

$\square$ No

口Don't Know / Not Applicable

22. List the three best practices that have made ordinance compliance successful or have been implemented to increase compliance. You are free to add more best practices if you would like.

Answer Options

Response Count

12

Answered question 


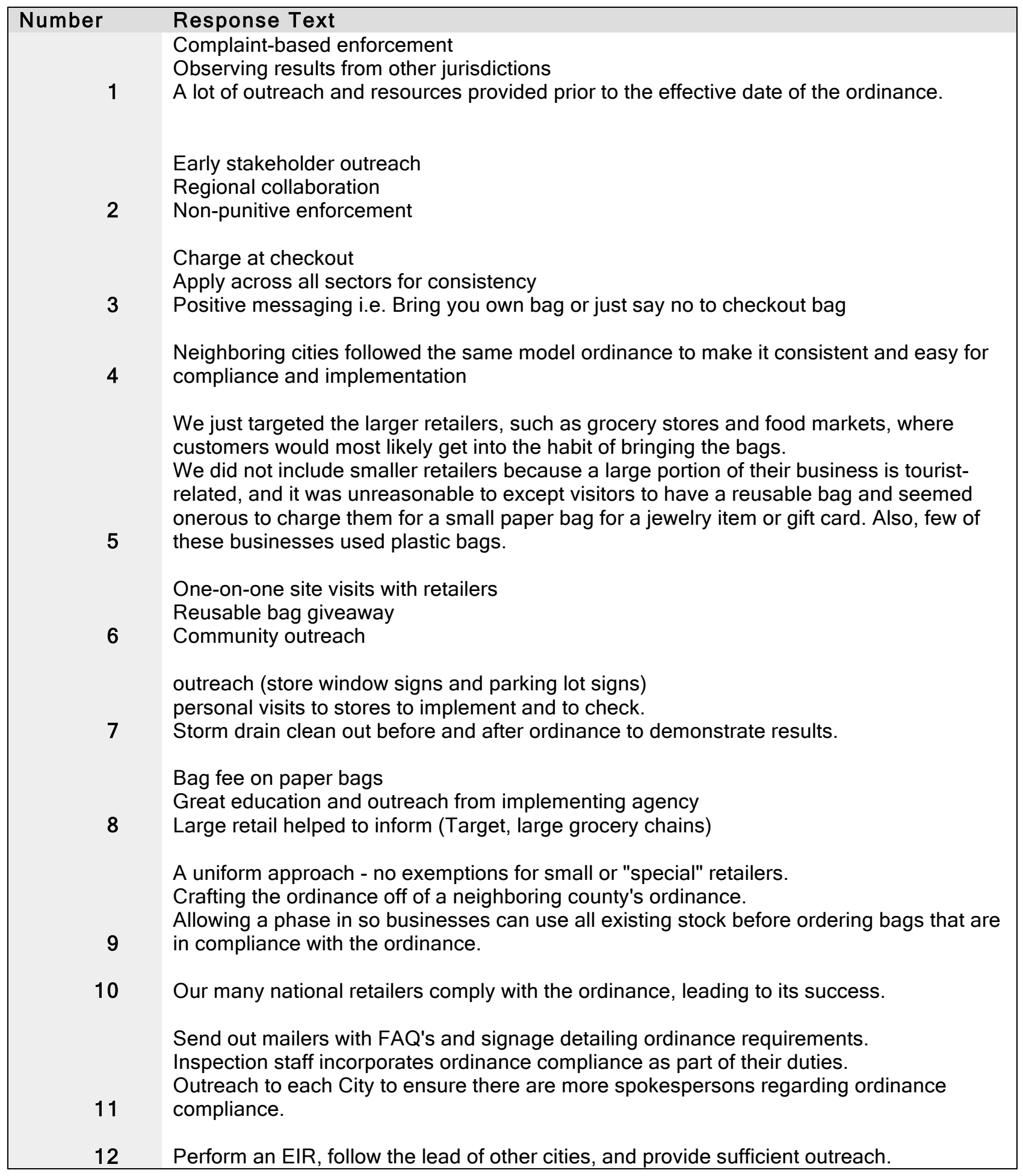




\section{Appendix B: Retail Bag Ordinance Survey (Non-Adopter)}

\begin{tabular}{|c|c|}
\hline \multirow[t]{4}{*}{ Answer Options } & \multirow{2}{*}{$\begin{array}{c}\text { Response Count } \\
8\end{array}$} \\
\hline & \\
\hline & 8 \\
\hline & 0 \\
\hline Number & esponse Text \\
\hline 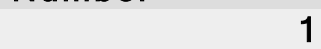 & 116,000 \\
\hline 2 & 72,000 \\
\hline 3 & 20,001 \\
\hline 4 & 27,618 \\
\hline 5 & 78,000 \\
\hline 6 & 107,684 \\
\hline 7 & 19,190 \\
\hline 8 & 103,000 \\
\hline
\end{tabular}

2. Is your city currently considering implementing an ordinance regulating the use and distribution of single-use plastic bags, reusable bags and recyclable paper bags?

Answer Options

Response

Response

Yes

Percent

Count

No

$37.5 \%$

3

Don't Know / Not Applicable

$62.5 \%$

$0.0 \%$

0 
Is your city currently considering implementing an ordinance regulating the use and distribution of single-use plastic bags, reusable bags and recyclable $0.0 \%$ paper bags?

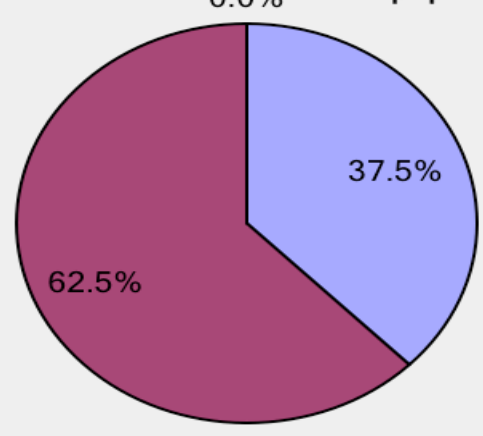

口Yes

aNo

口Don't Know / Not Applicable

3. If your city is not currently considering such an ordinance, do you think your city's decision makers consider an ordinance in the future?

Answer Options

Yes

No

Don't Know / Not Applicable

\section{Response Percent}

$14.3 \%$

$42.9 \%$

$42.9 \%$

Answered question

Skipped question
Response Count

1

3

3

If your city is not currently considering such an ordinance, do you think your city's decision makers consider an ordinance in the future?

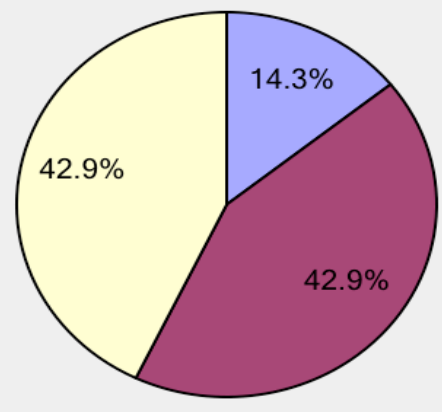

$$
\text { 口Yes }
$$

aNo

口Don't Know / Not Applicable 


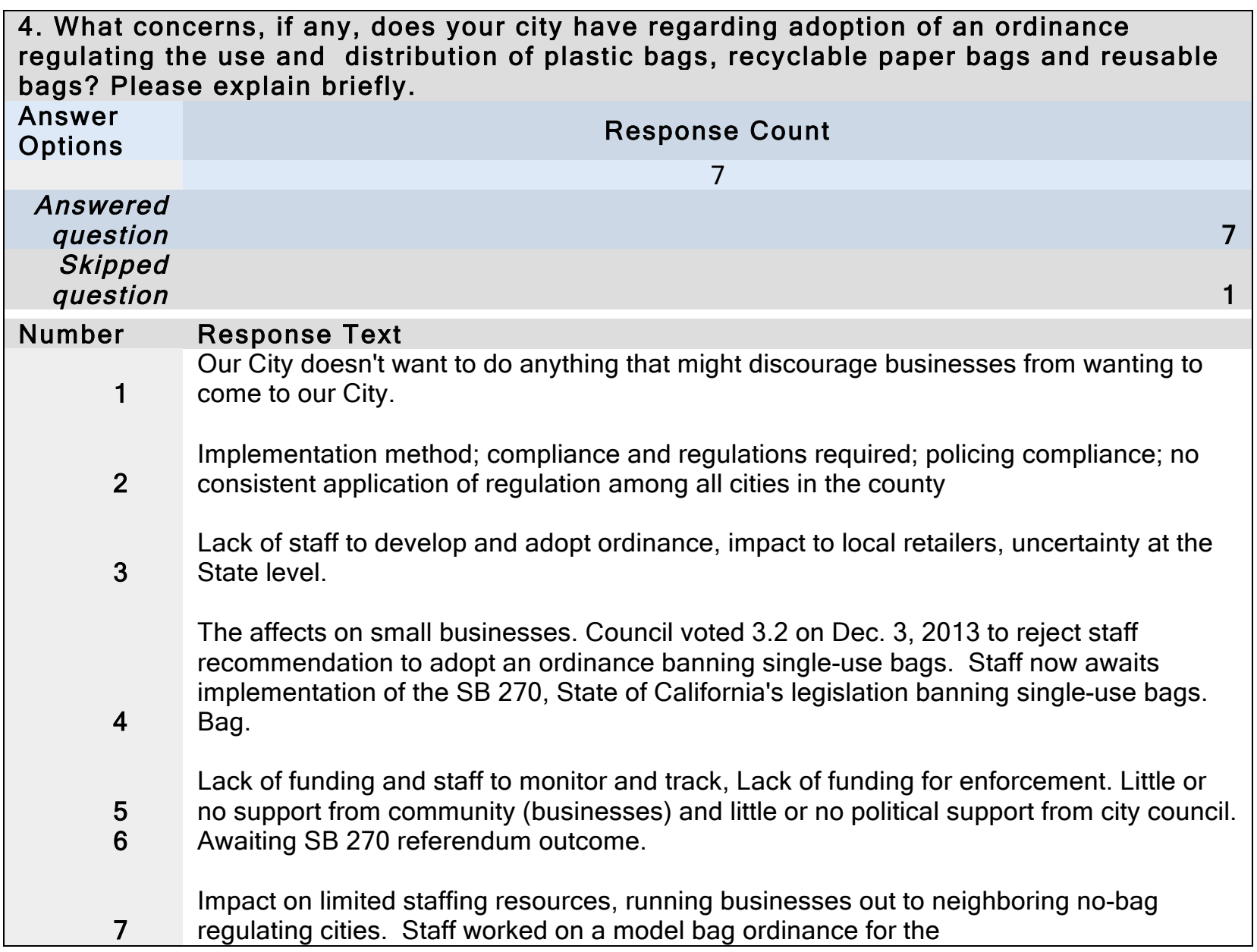




\begin{tabular}{|lcc|}
\hline \multicolumn{2}{|l}{ 5. Is your city researching similar ordinances from other } \\
cities? \\
Answer Options & $\begin{array}{c}\text { Response } \\
\text { Percent }\end{array}$ & $\begin{array}{c}\text { Response } \\
\text { Count }\end{array}$ \\
Yes & $50.0 \%$ & 4 \\
No & $50.0 \%$ & 4 \\
Don't Know / Not Applicable & $0.0 \%$ & 0 \\
& Answered question & 8 \\
& Skipped question & \\
\hline
\end{tabular}

\begin{tabular}{|c|c|c|}
\hline Answer Options & $\begin{array}{c}\text { Response } \\
\text { Percent }\end{array}$ & $\begin{array}{l}\text { Response } \\
\text { Count }\end{array}$ \\
\hline Yes & $0.0 \%$ & 0 \\
\hline No & $100.0 \%$ & 8 \\
\hline \multirow[t]{3}{*}{ Don't Know / Not Applicable } & $0.0 \%$ & 0 \\
\hline & red question & 8 \\
\hline & ped question & 0 \\
\hline
\end{tabular}

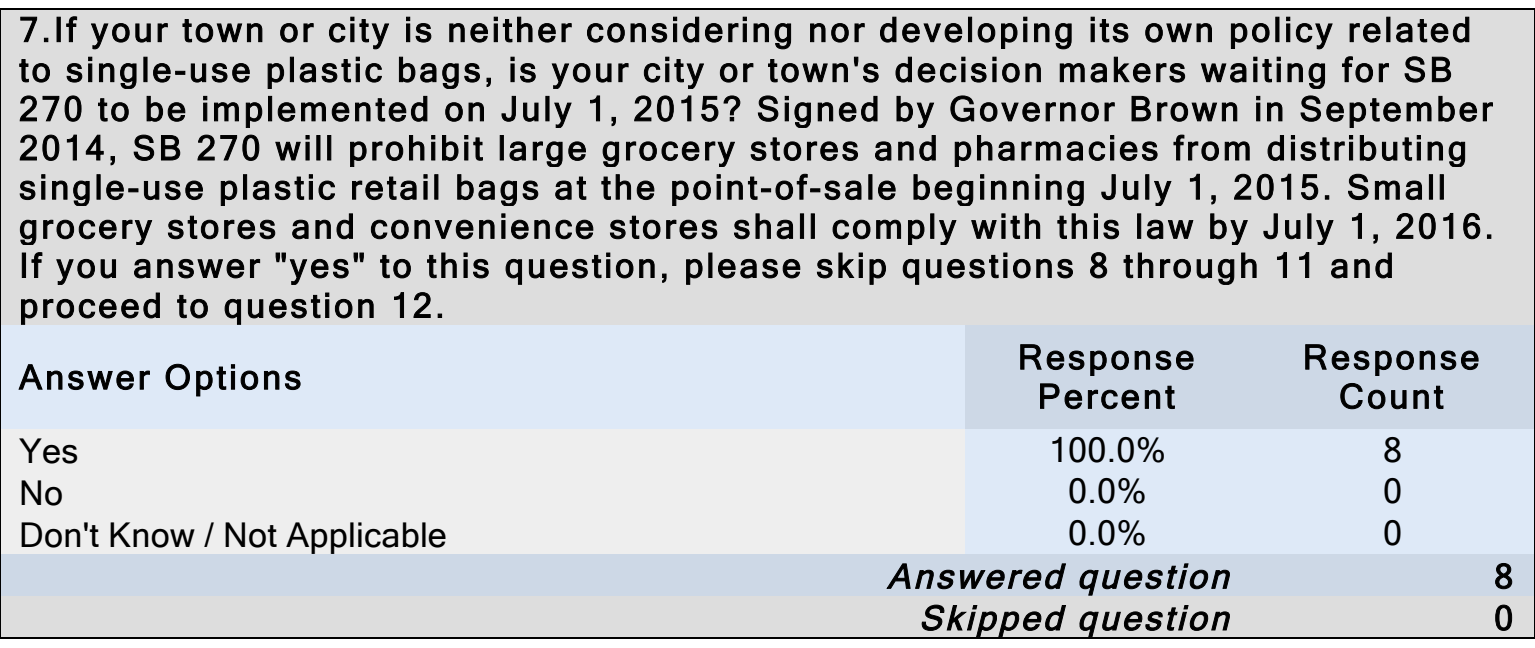




\begin{tabular}{|c|c|}
\hline $\begin{array}{l}\text { 8. If your } \\
\text { reviewed }\end{array}$ & $\begin{array}{l}\text { is researching other cities' ordinances, list which cities are being } \\
\text { w. }\end{array}$ \\
\hline $\begin{array}{l}\text { Answer } \\
\text { Options }\end{array}$ & Response Count \\
\hline & 2 \\
\hline $\begin{array}{r}\text { Answered } \\
\text { question }\end{array}$ & 2 \\
\hline $\begin{array}{l}\text { Skipped } \\
\text { question }\end{array}$ & 6 \\
\hline Number & Response Text \\
\hline 1 & $\begin{array}{l}\text { The Community Sustainability Commission (CSC) subcommittee researched ordinances } \\
\text { in the past with the assistance of the Local Government Commission. Many cities } \\
\text { responded to our information request, but I do not know what cities. } \\
\text { I am answering these questions, as even though we are not considering adopting a bag } \\
\text { ordinance at this time, we did all the research/work on it and have one ready to go. Staff } \\
\text { worked on a committee of the Clean Water Program to adopt a model ordinance for the } \\
\text { county. A similar version was adopted by a neighboring city and staff has discussed their } \\
\text { effort and results. }\end{array}$ \\
\hline
\end{tabular}

\begin{tabular}{|c|c|}
\hline $\begin{array}{l}\text { 9. Please briefly e } \\
\text { ordinances, if app }\end{array}$ & $\begin{array}{l}\text { xplain why your city is reviewing the above listed cities' } \\
\text { icable. }\end{array}$ \\
\hline Answer Options & Response Count \\
\hline & 2 \\
\hline $\begin{array}{r}\text { Answered } \\
\text { question }\end{array}$ & 2 \\
\hline $\begin{array}{l}\text { Skipped } \\
\text { question }\end{array}$ & $\left.e^{2}+2\right)$ \\
\hline Number & Response Text \\
\hline 1 & $\begin{array}{l}\text { To determine best practices and what ordinance would fit will in our } \\
\text { city. }\end{array}$ \\
\hline 2 & The City of..is a neighboring city with many similarities. \\
\hline
\end{tabular}


10. Briefly explain what your city learned or has learned from other municipalities' experiences in adopting and implementing their ordinances.

Answer

Options

\section{Response Count}

3
Answered
question
Skipped
question

Number

1 Cannot comment, have not been very involved in the research effort.

2

Quantifiable reduction in plastic bags in the creeks and other cleanup areas (City of San Jose).

3

There were very few issues and the public has had little effort in changing behavior.

11. How far along would you say your city is in developing a reusable bag policy?

Answer Options

Reviewing other cities' policies

Developing a retail bag policy

Adopting a retail bag policy

Implementing a retail bag policy

Evaluating a retail bag policy

\section{Response \\ Percent}

$50.0 \%$

$50.0 \%$

$0.0 \%$

$0.0 \%$

$0.0 \%$

Answered question

Skipped question

\section{Response Count}

\section{1}

1

0

0

0 
13. If you answered "Yes" to the previous question, did your city face challenges in meeting the SF Bay Regional Water Quality Control Board's storm drain litter reduction target mandate of $40 \%$ by July 1,2014 . If so, what were the challenges? Please type your answers in the space below.

Answer

Options

Response Count

6

Answered
question
Skipped
question

Number Response Text

1 Not to my knowledge

2 No

3 from their parking lots

$4 \quad$ Unknown.

Yes, we did not obtain the $40 \$$ trash load reduction required by the Municipal Storm Water Permit issued by the Board. We will, however, exceed the $40 \%$ goal by July 1 , 52015 and will work diligently to the $70 \%$ reduction goal in 2017 .

$6 \quad$ Not applicable

\begin{tabular}{|c|c|c|c|c|}
\hline $\begin{array}{l}\text { Answer } \\
\text { Options }\end{array}$ & Yes & No & $\begin{array}{c}\text { Don't Know / } \\
\text { Not } \\
\text { Applicable }\end{array}$ & $\begin{array}{c}\text { Response } \\
\text { Count }\end{array}$ \\
\hline Creeks & 5 & 1 & 2 & 8 \\
\hline Streams & 5 & 1 & 2 & 8 \\
\hline Waterways & 5 & 1 & 2 & 8 \\
\hline $\begin{array}{l}\text { Public } \\
\text { Space }\end{array}$ & 5 & 1 & 2 & 8 \\
\hline & & & $\begin{array}{l}\text { vered question } \\
\text { pped question }\end{array}$ & \\
\hline
\end{tabular}




\begin{tabular}{|c|c|c|}
\hline $\begin{array}{l}\text { 15. How much } \mathrm{m} \\
\text { collection and ab } \\
\text { time periods? } \mathrm{PI} \\
\text { answer this ques }\end{array}$ & $\begin{array}{l}\text { r city spend } \\
\text { bags for th } \\
\text { below. If y } \\
\text { Don't Know' }\end{array}$ & $\begin{array}{l}\text { n litter } \\
\text { following } \\
\text { u cannot }\end{array}$ \\
\hline Answer Options & $\begin{array}{c}\text { Response } \\
\text { Percent }\end{array}$ & $\begin{array}{c}\text { Response } \\
\text { Count }\end{array}$ \\
\hline $\begin{array}{l}\text { One Month: } \\
\text { Fiscal Year: } \\
\text { Don't Know: }\end{array}$ & $\begin{array}{l}16.7 \% \\
33.3 \% \\
66.7 \%\end{array}$ & $\begin{array}{l}1 \\
2 \\
4\end{array}$ \\
\hline & $\begin{array}{l}\text { ed question } \\
\text { ed question }\end{array}$ & $\begin{array}{l}6 \\
2\end{array}$ \\
\hline Number & $\begin{array}{l}\text { One } \\
\text { Month: }\end{array}$ & $\begin{array}{l}\text { Fiscal } \\
\text { Year: }\end{array}$ \\
\hline $\begin{array}{l}1 \\
2 \\
3 \\
4 \\
5 \\
6\end{array}$ & Varies & $\begin{array}{r}\$ 250,000.00 \\
\$ 6,000.00\end{array}$ \\
\hline
\end{tabular}

16. Litter reduction in the form of single-use plastic bags in creeks, rivers, streams and waterways. Circle one of the following choices:

Answer Options

Not Successful

Somewhat Successful

Successful

Response

Percent

Response

$0.0 \%$

$50.0 \%$

$12.5 \%$

Very Successful

$0.0 \%$

$37.5 \%$

Count

Don't Know / Not Applicable

0
4
1
0
3

Answered question

Skipped question

17. Litter reduction in the form of single-use plastic bags in storm drains. Circle one of the following choices:

Answer Options

Response Percent Response Count

Not Successful

$0.0 \%$

0

Somewhat

Successful

$50.0 \%$

4

Successful

$12.5 \%$

1

Very Successful

$0.0 \%$

0

Don't Know / Not

$37.5 \%$

3

Answered question

Skipped question 
18. Below is a list of groups, agencies and organizations that are most likely affected by any future reusable bag ordinance and or plastic bag ordinance in your city. Based on your perceptions and experiences do you feel each has a favorable attitude toward the ordinance, an unfavorable attitude, an indifferent attitude, or do you not have enough information to make this assessment?

\section{Answer Options \\ Favorable \\ Unfavorable \\ Indifferent}

Consumers

Retailers

Restaurateurs

City Council

Mayor

City Manager

Environmental Dept.

Public Works Dept.

Plastics Industry

$\begin{array}{ll}6 & 0 \\ 2 & 2 \\ 1 & 4 \\ 4 & 1 \\ 6 & 1 \\ 5 & 0 \\ 6 & 0 \\ 5 & 0 \\ 0 & 5\end{array}$

Don't Know / Not Applicable

Response Count

2
2
0
2
0
1
0
3
0

0

2

3

1

1

2

2

0

3

Answered question

Skipped question

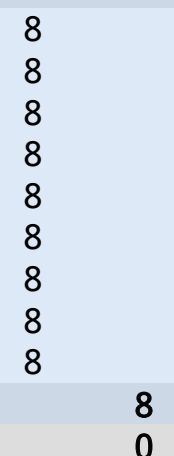

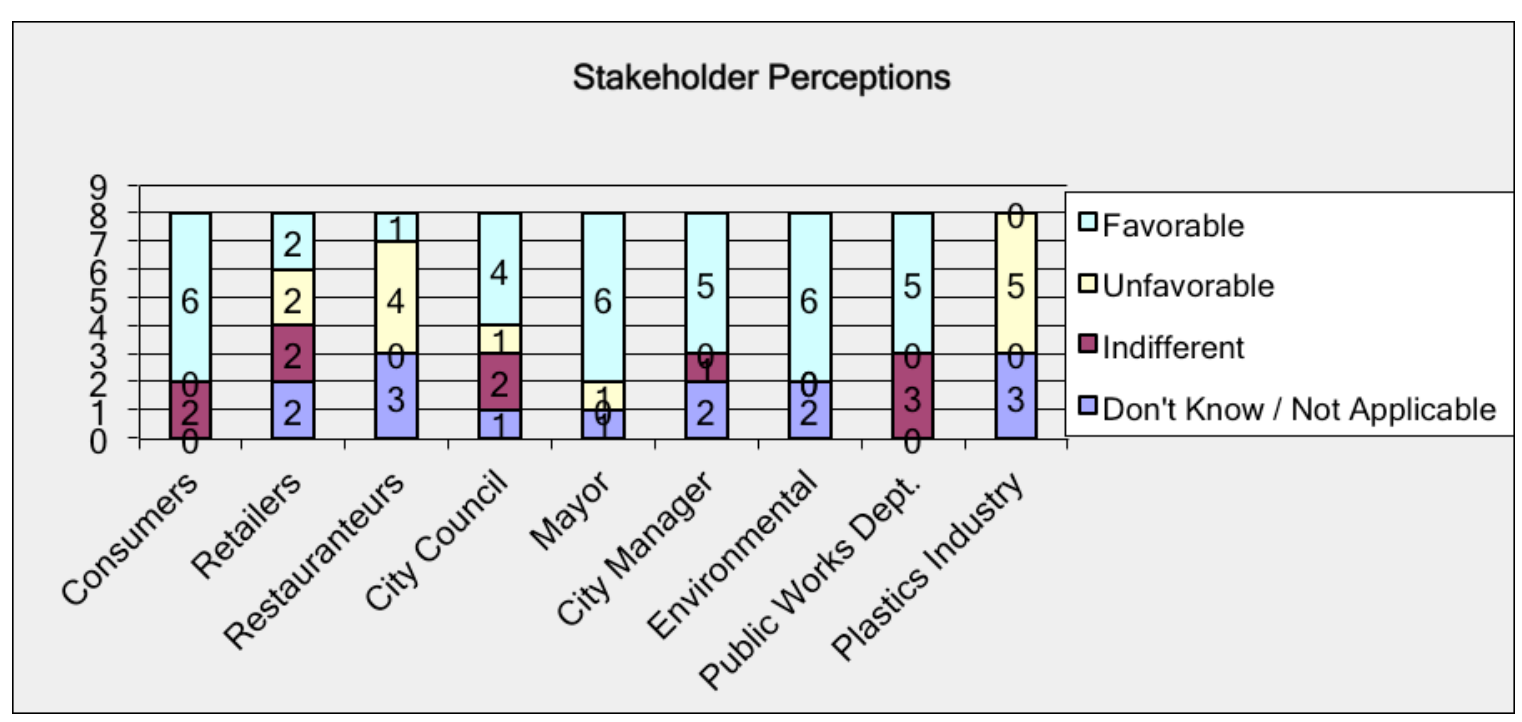




\begin{tabular}{|c|c|c|}
\hline $\begin{array}{l}\text { 19. Often in the policym } \\
\text { behavior is appropriate } \\
\text { decision-making. Based } \\
\text { believe single-use plasti } \\
\text { reusable bags are the be }\end{array}$ & $\begin{array}{l}\text { eas and be } \\
\text { t-large can } \\
\text { nce, do citi } \\
\text { nvironment } \\
\text { ailable? }\end{array}$ & $\begin{array}{l}\text { bout what } \\
\text { shape } \\
\text { n your city } \\
\text { ger and that }\end{array}$ \\
\hline Answer Options & $\begin{array}{c}\text { Response } \\
\text { Percent }\end{array}$ & $\begin{array}{c}\text { Response } \\
\text { Count }\end{array}$ \\
\hline Yes & $62.5 \%$ & 5 \\
\hline No & $37.5 \%$ & 3 \\
\hline Don't Know / Not Applicable & $0.0 \%$ & 0 \\
\hline & ered quest & 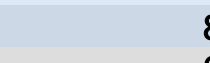 \\
\hline & oped quest & ( \\
\hline
\end{tabular}

\section{List the three best practices that have made regulating the use and distribution of single-use plastic bags, reusable bags and recycled bags without an ordinance effective. You can list more examples if you wish.}

\section{Answer \\ Options}

Answered

question

Skipped

question
Response Count

6

\begin{tabular}{|c|l|} 
Number & $\begin{array}{l}\text { Response Text } \\
\text { Participated In Bring Your Own Bag Campaign with Bay Roc } \\
\text { Distributed Reusable Bags At Special Events } \\
\text { Outreach and Education Regarding Importance of using recycled bags. }\end{array}$ \\
$\begin{array}{c}\text { Incentives from stores; selling reusable bags in the store; groups who give out } \\
\text { reusable bags at community events or other establishments; dispelling myths that } \\
\text { exist re: cleanliness of bags }\end{array}$ \\
$\begin{aligned} \text { I haven't seen it effective without an ordinance } \\
3\end{aligned}$ & $\begin{array}{l}\text { Promoting effective use of reusable bags in advertising on City's website, at civic } \\
\text { and special events. }\end{array}$ \\
& $\begin{array}{l}\text { We don't regulate. Large retail stores support one bill to try to create consistency at } \\
\text { all their stores throughout the state. }\end{array}$ \\
6 & I have none to report
\end{tabular}




\section{References}

ASTM International. (2013). ASTM D-6400: Standard Specification for Labeling of Plastics Designed to be Aerobically Composted in Municipal or Industrial Facilities. Retrieved November 23, 2013, from http://www.astm.org/search/fullsite-search.html?query=D6400\&

Bardach, E. (2012). A practical guide for policy analysis. Los Angeles, CA: CQ Press

Bardelline, J. (2011, January 5). Italy dumps plastic bags with Europe's first nationwide ban. Greebiz.com. Retrieved, October 5, 2013, from http://www.greenbiz.com/news/2011/01/05/italy-dumps-plastic-bags-world-first-nationwideban?page=full.

California Coastal Commission. (2013). The Problem with Marine Debris. Retrieved November 23, 2013, from http://www.coastal.ca.gov/publiced/marinedebris.html

California Department of Finance (2013, May 1). Tables of January 2013 City Population by Size, Numeric and Percent Change.

California Legislative Information. (2013, May 24). SB405 Solid Waste: Single-Use Carryout Bags. Chapter 5.3. Retrieved October 5, 2013, from http://leginfo.legislature.ca.gov/faces/billCompareClient.xhtml

California Legislative Information. (2010, August 27). AB 1998 Solid Waste: Single-Use Carryout Bags. Chapter 5.3. Retrieved November 18, 2013, from http://leginfo.legislature.ca.gov/faces/billCompareClient.xhtml

California Legislative Information. (2006, September 30) AB 2449 Recycling: Plastic Carryout Bags. Chapter 5.1. Retrieved November 18, 2013, from http://leginfo.legislature.ca.gov/faces/billCompareClient.xhtml

California State Water Resources Control Board. (2013a, August 9). Fact Sheet: Control of Trash Entering Waterways in California. Retrieved November 18, 2013, from http://www.waterboards.ca.gov/water_issues/programs/trash_control/docs/trash_fs.pdf

California State Water Resources Control Board. (2013b, June 12). Fact Sheet: Storm Water Management in California. Retrieved November 18, 2013, from http://www.waterboards.ca.gov/water_issues/programs/stormwater/docs/stormwater_factshee t.pdf

California State Water Resources Control Board. (2014, June 6). National Pollutant Discharge Elimination System (NPDES) - Wastewater. Retrieved August 9, 2014, from http://www.waterboards.ca.gov/water_issues/programs/npdes/ 
Californians Against Waste. (2013). Plastic bags: Local ordinances. Retrieved October 5, 2013, from http://www.cawrecycles.org/issues/plastic campaign/plastic bags/local

Californians Against Waste. (2014). Plastic bags: Local ordinances. Retrieved February 18, 2015, from http://www.cawrecycles.org/issues/plastic_campaign/plastic_bags/local

Clapp, J., \& Swanston, L. (2009). Doing away with plastic shopping bags: International patterns of norm emergence and policy implementation. Environmental Politics, 18(3), 315-332. doi:10.1080/09644010902823717

Courchaine, L. (2013, July 3). Reducing Waste: the plastic bag ban bandwagon. The San Jose Mercury News. Retrieved October 5, 2013, from http://www.mercurynews.com/ci 23592062/reducing-waste-plastic-bag-banbandwagon?IADID=Search-www.mercurynews.com-www.mercurynews.com

Creswell, J.W. (2003). Research design: qualitative, quantitative and mixed methods approaches. Thousand Oaks, CA: Sage Publications, Inc.

The Department of the Environment, San Francisco. (2012, October 5). Mayor Lee Announces San Francisco Reaches 80 Percent Landfill Waste Diversion, Leads All Cities in North America. Retrieved November 23, 2013, from http://www.sfenvironment.org/news/pressrelease/mayor-lee-announces-san-francisco-reaches-80-percent-landfill-waste-diversionleads-all-cities-in-north-america

The Delaware Valley Citizens' Council for Clean Air. (n.d.). Waste and Recycling Facts. Retrieved November 23, 2013, from http://www.cleanair.org/Waste/wasteFacts.html

Environmental Protection Agency. (2013a, October 4). Vocabulary Catalog List Detail - Core Ecosystem Services Research Program Standard Lexicon. Retrieved October 6, 2013, from http://ofmpub.epa.gov/sor internet/registry/termreg/searchandretrieve/glossariesandkeywordl ists/search.do?details $=\&$ glossaryName $=$ Core $\% 20$ ESRP $\% 20$ Standard $\% 20$ Lexicon

Environmental Protection Agency. (2013b, July 10). Plastics: Common Wastes and Materials. Retrieved October 6, 2013, from http://www.epa.gov/osw/conserve/materials/plastics.htm.

Environmental Protection Agency. (2015, January 30). Documents Related to the Proposed Definition of 'Waters of the United States' Under the Clean Water Act. Retrieved April 17, 2015, from http://www2.epa.gov/cleanwaterrule/documents-related-proposed-definitionwaters-united-states-under-clean-water-act

Gabrielsen, P. (2013, July 16). Do plastic bag bans really reduce litter? Santa Cruz Sentinel. Retrieved October 6, 2013, from http://www.mercurynews.com/ci 23670700/do-plastic-bagbans-really-reduce-litter?IADID=Search-www.mercurynews.com-www.mercurynews.com 
Green, J. (2013, March 9). Palo Alto ban on plastic bags could expand. The San Jose Mercury News. Retrieved October 5, 2013, from http://www.mercurynews.com/ci 22754250/paloalto-ban-plastic-bags-could-expand?IADID=Search-www.mercurynews.comwww.mercurynews.com.

Green, J. (2013, June 28). Expanded plastic bag bans to take effect Monday in Palo Alto. The San Jose Mercury News. Retrieved October 5, 2013, from http://www.mercurynews.com/ci_23565381/expanded-plastic-bag-take-effect-monday-paloalto?IADID=Search-www.mercurynews.com-www.mercurynews.com.

Gorn, D. (2008, March 27). San Francisco plastic bag ban interests other cities. National Public Radio. Retrieved October 6, 2013, from http://www.npr.org/templates/story/story.php?storyId=89135360.

Hindrey, R. (2010, September 1). California plastic bag ban rejected by state lawmakers. Huffington Post. Retrieved October 5, 2013, from http://www.huffingtonpost.com/2010/09/01/california-plastic-bag-ba 0 n 701952.html.

Karch, A. (2007). Emerging Issues and Future Directions in State Policy Diffusion Research. State Politics \& Policy Quarterly, 7(1), 54-80.

Lewis, H., Verghese, K., \& Fitzpatrick, L. (2010). Evaluating the sustainability impacts of packaging: The plastic carry bag dilemma. Packaging Technology and Science, 23(3), 145 160. doi:10.1002/pts.886

Merriam-Webster Dictionary. (2015a). Retrieved April 17, 2015, from http://www.merriam-webster.com/dictionary/creek

Merriam Webster Dictionary. (2015b). Retrieved April 17, 2015, from http://www.merriam-webster.com/dictionary/storm\%20drain

Merriam-Webster Dictionary. (2015c). Retrieved April 17, 2015, from http://www.merriam-webster.com/dictionary/waterway

Ocean Crusaders. (n.d.). Plastic statistics: Plastic ain't so fantastic. Retrieved November 18, 2013, from http://oceancrusaders.org/plastic-crusades/plastic-statistics/

Olson, L. (October 30, 2013). California's plastic bag recycling law has no oversight, Investigation finds. San Jose Mercury News. Retrieved November 18, 2013, from http://www.mercurynews.com/politics-government/ci_24419047/californias-plastic-bagrecycling-law-has-no-oversight

Paper or Plastic? (2008). Current Events, 107(21), 7-7. Retrieved October 6, 2013 from http://search.ebscohost.com/login.aspx?direct=true \&db=aph\&AN=31501154\&site=ehostlive 
Palo Alto, CA. (2009). Disposable Checkout Bag Ordinance. Municipal Code.

Title 5, Chapter 5.35.

Palo Alto, CA. (2013a). Disposable Checkout Bag Ordinance. Municipal Code.

Title 5,Chapter 5.35.

Palo Alto, CA. (2013b, September 18). Palo Alto Reduction Ordinances. Retrieved October 6, 2013, from

http://www.cityofpaloalto.org/gov/depts/pwd/pollution/palo_alto_disposable_checkout_bag _ordinance.asp.

Palo Alto, CA. (2014a). Clean Bay Pollution Prevention Plan 2014.

Palo Alto, CA (2014b). City of Palo Alto Disposable Checkout Bag Ordinance Compliance: Survey Methodology and Results for Retailers with Stores 10,000 Square Feet and Greater.

Palo Alto, CA. (2014c, January 13). Long-Term Trash Load Reduction Plan and Assessment Strategy. Retrieved August 11, 2014, from http://www.cityofpaloalto.org/civicax/filebank/documents/38421

Palo Alto, CA (2014d, n.d.). Palo Alto Disposable Checkout Bag Ordinance: Store Exit Surveys of Customer Bag Types 2008-2014.

Reuse This Bag.com. (2010). Plastic bag usage: USA vs. the world. Retrieved November 18, 2013, from http://www.reusethisbag.com/reusable-baginfographics/plastic-bag-bansworld.php

Ritch, E., Brennan, C., \& MacLeod, C. (2009). Plastic bag politics: Modifying consumer behaviour for sustainable development. International Journal of Consumer Studies, 33(2), 168-174. doi:10.1111/j.1470-6431.2009.00749.x

Rogers, P. (February 15, 2012). San Francisco bay: a garbage can for 7 million people. San Jose Mercury News. Retrieved August 10, 2014, from http://www.mercurynews.com/ci_19972044

Rosenthal, E. (2013, May 18). Is it time to bag the plastic? The New York Times. Retrieved October 5, 2013, from. http://www.nytimes.com/2013/05/19/sunday-review/should-americabag-the-plastic-bag.html?pagewanted=all.

Rosenthal, E. (2008, February 2). Motivated by tax, Irish spurn plastic bags. The New York Times. Retrieved October 5, 2013, from http://www.nytimes.com/2008/02/02/world/europe/02bags.html?pagewanted=all.

San Francisco, CA (2007). Plastic Bag Reduction Ordinance. Environmental Code. Chapter 17, Sections 1701-1709. 
San Francisco Achieves 77\% Landfill Diversion Rate, the Highest of Any U.S. City. (2010, August 30). Retrieved November 23, 2013, from http://www5.sfgov.org/sf_news/2010/08/san-francisco-achieves-77-landfill-diversion-ratethe-highest-of-any-us-city.html

San Francisco, CA (2012). Plastic Bag Reduction Ordinance. Environmental Code. Chapter 17, Sections 1702, 1703.5, 1704.

San Jose, CA (2012a). Bring Your Own Bag Ordinance. Municipal Code. Title 9, Chapter 9.10, Part 13.

San Jose, CA (2012b). Bring Your Own Bag Implementation Results and Actions to Reduce EPS Foam Ware. Memorandum. November 20.

San Jose, CA (2012c). Pre Post Store Observations Summary. Excel File. December 11.

San Jose, CA (2013a). Amendment to the Single-Use Carryout Bag Regulations. Memorandum. August 29.

San Jose, CA (2013b). Amendment to the Single-Use Carryout Bag Regulations. Memorandum. September 12.

San Jose, CA (2013c). Addendum to FIER: Single-Use Carryout Bag Ordinance. File No. PP13-078. July.

San Jose, CA (2013d). Bag Ban Metrics Table. Excel file.

San Mateo, CA (2012). Reusable Bags. County Ordinance Code. Title 4, Chapter 4.114.

Santa Clara County, CA (2011). Single-Use Carryout Bag Ban. County Ordinance Code. Title B, Division B11. Chapter XVII.

Santa Clara Valley Urban Runoff Pollution Prevention Program. (n.d.). About scvurppp. Retrieved March 21, 2015, from http://www.scvurppp-w2k.com/about_scvurppp.shtml

Shipan, C. R., \& Volden, C. (2008). The Mechanisms of Policy Diffusion. American Journal Of Political Science, 52(4), 840-857. doi:10.1111/j.1540-5907.2008.00346.x

Shipan, C.R., \& Volden, C. (2012). Policy Diffusion: Seven Lessons for Scholars and Practitioners. Public Administration Review, 72(6), 788-796.

Sierra Forest Legacy. (2012). Old growth forests of the Sierra Nevada. Retrieved November 18, 2013, from http://www.sierraforestlegacy.org/FC FireForestEcology/TH_Old-growthForests.php. 
SPI: The Plastics Trade Industry Association (2012). About SPI. Retrieved October 5, 2013, from http://www.plasticsindustry.org/AboutSPI/

Sylvia, R. \& Sylvia, K. (2004). Program planning and evaluation for the public manager. Long Grove, IL: Waveland Press, Inc.

Wilson, A. (2013, August 8). Sunnyvale tweaks single-use carryout bag ordinance to match San Jose's.” The San Jose Mercury News. Retrieved October 5, 2013, from http://www.mercurynews.com/ci 23901952/sunnyvale-tweaks-single-use-carryout-bagordinance-match?IADID=Search-www.mercurynews.com-www.mercurynews.com.

Wilson, M. (September 25, 2013). Cupertino's bag ban begins Oct. 1. San Jose Mercury News. Retrieved November 18, 2013, from

http://www.mercurynews.com/cupertino/ci 24142496/cupertinos-bag-ban-begins-oct-1 